\title{
МАТЕРІАЛИ КОНГРЕСУ АНЕСТЕЗІОЛОГІВ УКРАЇНИ
}

\section{9-21 вересня 2019 року}

\author{
УДК : 616.155.392:616-009.7:6616-082.5:615 \\ Адамчук Н.H. ${ }^{1}$, Сорокіна О.Ю. ${ }^{2}$

\section{СУЧАСНІ ПІДХОДИ ДО ТЕРАПІЇ ГОСТРОГО БОЛЮ У ДІТЕЙ 3 ОНКОПАТОЛОГІЄЮ ТА ПЕРЕНОСИМІСТЬ ЗНЕБОЛЕННЯ В ЗАЛЕЖНОСТІ ВІД МЕТОДУ \\ 1 «Українська медична стоматологічна академія», м. Полтава, Україна, ${ }^{2}$ Д3 «Дніпропетровська медична академія МОЗ України», м. Дніпро, Україна}

\section{Вступ}

Больовий синдром є одним із ускладнень у дітей 3 гострими лейкозами, що потребує своєчасної та ефективної знеболювальної терапії.

\section{ЦІль}

Визначити переносимість аналгетиків та ступінь психоемоційних порушень у дітей 3 гострими лейкозами в залежності від методу знеболення.

\section{МАТЕРІАЛИ ТА МЕТОДИ}

Проведено обстеження 60 дітей (3 групи по 20 дітей в кожній). В I групі проводилось знеболення морфіном. В II групі - морфіном в комбінації з габапентином, та в III групі - НПЗ3 з габапентином. Досліджувались показники роботи серцево-судинної системи, шлунково-кишкового тракту. Використовувався опитувальник «САН» для визначення психоемоційних порушень.

\section{РЕЗУЛЬТАТИ}

В I групі у всіх дітей відмічались порушення функціі шлунково-кишкового тракту та лабільність артеріального тиску. В II групі тільки у 11 дітей відмічались порушення $з$ боку травної системи, з боку серцево-судинної ускладнень не було. В III групі лише у 5 дітей мала місце лабільність артеріального тиску. Середні показники активності у всіх трьох групах практично однакові і відобража- ють благоприємний стан. Середні показники самопочуття найнижчі у I групі - 3,78 $\pm 0,11(\mathrm{p}<0,05)$, у другій групі $3,84 \pm 0,06(\mathrm{p}<0,05)$, і у третій $-4,01 \pm 0,09(\mathrm{p}<0,05)$. Показники настрою у II та III групах практично однакові -

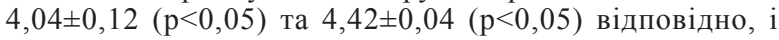

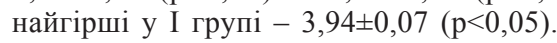

\section{висновки}

Найкраща переносимість знеболення у дітей, що отримували НП33 з габапентином, найгірша - у дітей, що отримували тільки опіати. У дітей, яким проводилось комбінування опіатів з габапентином, кращі показники САН і значно менше ускладнень в порівнянні з дітьми, що отримували тільки опіати.

\section{СПИСОК ЛІТЕРАТУРИ}

1. Liossi C, Anderson AK, Howard RF. Development of research priorities in paediatric pain and palliative care. Br J Pain. 2017 Feb;11(1):9-15. doi: 10.1177/2049463716668906

2. Kaguelidou F, Le Roux E, Mangiarini L. Non-inferiority double-blind randomised controlled trial comparing gabapentin versus tramadol for the treatment of chronic neuropathic or mixed pain in children and adolescents: the GABA-1 trial-a study protocol. BMJ Open. $2019 \mathrm{Feb}$ 20;9(2):e023296. doi: 10.1136/bmjopen-2018-023296.

3. de Leeuw TG, Mangiarini L, Lundin R. Gabapentin as add-on to morphine for severe neuropathic or mixed pain in children from age 3 months to 18 years - evaluation of the safety, pharmacokinetics, and efficacy of a new gabapentinliquid formulation: study protocol for a randomized controlled trial. Trials. 2019 Jan 15;20(1):49. doi $10.1186 / \mathrm{s} 13063-018-3169-3$.

Babina U.M., Dmytriiev D.V., Nazarchuk O.A.

\section{COMPARATIVE STUDY OF INFILTRATION BETWEEN THREE LOCAL ANESTHETICS: BUPIVACAINE, LIDOCAINE AND ROPIVAKAIN ON WOUND HEALING IN RATS}

Vinnitsa national medical university, Ukraine.

\section{BACKGROUND AND OBJECTIVES}

The aim of this study was to comparative investigation the effects of saline solution, bupivacaine, lidocaine and ropivacaine infiltration on wound healing in rats.

\section{MATERIAL AND METHODS}

Fifty onemale Wistar rats weighing between 250-300 grams were randomly separated into four groups. Surgical procedures were done under general anesthesia, induced by intraperitoneal injection of $75 \mathrm{mg} \cdot \mathrm{kg}^{-1}$ ketamine. The hair on the back of the animal was shaved after the loss of cornea reflex and extremity drawing response were diminished. The area of the incision was cleaned with povidione iodine and was wiped dry with sterile gauges after two minutes. The areas of the incisions were subcutaneously infiltrated with 3 $\mathrm{ml}$ doses of the study drug. The rats in the groups were infiltrated with normal saline in control group (Group C, $\mathrm{n}=$ 13), $2 \%$ lidocaine in lidocaine group (Group $\mathrm{L}, \mathrm{n}=13$ ), $0.5 \%$ bupivacaine in bupivacaine group (Group $\mathrm{B}, \mathrm{n}=13$ ), and $0,75 \%$ ropivacaine in ropivacaine group (Group $\mathrm{R}, \mathrm{n}=12$ ). Breaking-strength measurements, collagen bundle counting, and histopathologic evaluation were evaluated in the tissue samples taken from the rats.

\section{RESULTS}

Comparing the control group with the groups where bupivacaine and lidocaine were used for wound infiltration, collagen production was lower, breaking-strength measurements showed reduced resistance while significantly high edema, vascularity, inflammation scores were found 
( $p<0.0122)$. Between the control and the ropivacaine group there were no significant differences in collagen production, breaking-strength measurements, and edema, vascularity, inflammation scores $(\mathrm{p}>0.0118)$.

\section{CONCLUSION}

Surgical wound infiltration has been proven to be an effective analgesic and is widely used for postoperative pain relief after abdominal hysterectomy, cesarean section, inguinal hernia repair, lumbar disc hernia, prostatectomy and similar surgeries. Frequently used local anesthetic agents are lidocaine, bupivacaine, ropivacaine. Research on the effect of these local anesthetic agents used for wound infiltration on wound healing is limited and results are controversia. In our study, we found bupivacaine and lidocaine reduced the

collagen production, wound breaking strength, and caused significantly high scores for edema, vascularity, and inflammation when compared to the control group. There was no significant difference between the control and the ropivacaine group. Results of this experimental preliminary study on rats support the idea that ropivacaine can be used for wound infiltration anesthesia without adverse effect on the surgical healing process. These results need to be verified in humans.

Keywords: anesthesia local; ropivacaine; bupivacaine; lidocaine; wound healing.

\section{REFERENCES}

1. Hancэ, Volkan, et al. "Comparison of the effects of bupivacaine, lidocaine, and tramadol infiltration on wound healing in rats." Revistabrasileiradeanestesiologia 62.6 (2012): 804-810.

\section{УДК 616.6-001.8-008.6-07-08-053.31 \\ Бабінцева А.Г., Годованець Ю.Д., Агафонова Л.В., Кошурба І.В. \\ ІНТЕНСИВНА ТЕРАПІЯ У НЕОНАТАЛЬНОМУ ПЕРІОДІ: ДОДІАЛІЗНИЙ МЕНЕДЖМЕНТ ГОСТРОГО ПОШКОДЖЕННЯ НИРОК}

ВДНЗ України «Буковинський державний медичний університет», м. Чернівці, Україна

\section{АКТУАЛЬНІСТЬ}

Враховуючи важливу роль сечової системи у забезпеченні стабільності гомеостазу цілого організму та високу частоту формування ренальної дисфункції у критично хворих новонароджених дітей, лікувальна тактика пацієнтів неонатальних відділень інтенсивної терапії вимагає системного підходу, спрямована на протекцію життєво важливих функцій, у тому числі, попередження формування гострого пошкодження нирок (ГПН) [1-4].

\section{МЕТА ДОСЛІДЖЕННЯ}

Удосконалити комплекс інтенсивної терапї̈ у критично хворих новонароджених для попередження та лікування ГПН, оцінити його ефективність.

\section{МАТЕРІАЛИ ТА МЕТОДИ}

Проведено комплексне клініко-параклінічне обстеження 100 доношених критично хворих новонароджених, 3 яких 60 дітям було призначено удосконалений лікувальний комплекс (основна група), 40 дітей отримували загальноприйняту терапію (група порівняння). Новонародженим основної групи, поряд із традиційними заходами стабілізації гомеостазу, було призначено засіб із групи метилксантинів, який попереджає аденозин-індуковану ренальну вазоконстрикцію, та препарат антигіпоксичної й антиоксидантної дії, основною діючою речовиною якого є бурштинова кислота, нікотинамід, рибоксин та рибофлавін.

\section{РЕЗУЛЬТАТИ}

Застосування удосконаленого лікувального комплексу, порівняно з традиційною терапією, надало змогу суттєво покращити якість функціонування сечової системи при важких формах перинатальної патології, зокрема зменши- ти частоту випадків формування ГПН у 1,9 рази. При лікуванні новонароджених відмічалося зростання погодинного діурезу, зменшення рівня креатиніну у сироватці крові, збільшення швидкості клубочкової фільтрації, покращення основних допплерометричних показників ренального кровоплину та стабілізація балансу маси тіла. Стимуляція антиоксидантного ефекту захисту організму підтверджувалося суттєвим зменшенням рівня малонового альдегіду в еритроцитах та окисної модифікації білків у плазмі крові, збільшенням активності глюкозо-6-фосфатдегідрогенази в еритроцитах, глутатіонредуктази та глутатіон-S-трансферази у плазмі крові.

\section{висновки}

Результати проведеного дослідження засвідчили доцільність використання призначеного лікувального комплексу, поряд із традиційним лікуванням, що підтверджується нормалізацією становлення ренальних функцій за умов перинатальної гіпоксії та зменшенням тяжкості перебігу нозологічної патології у новонароджених дітей в ранньому неонатальному періоді.

\section{СПИСОК ЛІТЕРАТУРИ}

1. Jetton JG, Boohaker LJ, Sethi SK, Wazir S, Rohatgi S, Soranno DE et al. Incidence and outcomes of neonatal acute kidney injury (AWAKEN): a multicentre, multinational, observational cohor study. Lancet Child Adolesc
$10.1016 / S 2352-4642(17) 30069-X$

2. Pandey $V$ Kumar D, Vijayaraghavan $P$ Chaturvedi $T$, Raina $R$ Nondialytic management of acute kidney injury in newborns. J Renal Inj Prev. 2017:6(1):1-11. DOI: 10.15171\%2Firip.2017.01.

3. Kidney Disease: Improving Global Outcomes (KDIGO) Acute Kidney Injury Work Group. KDIGO clinical practice guideline for acute kidney injury. Kidney Int. 2012:2:1-126.

4. Sathe KP, Kulkarni A. Review article: role of methylxanthines in preventing acute renal failure in hypoxic newborns. Apollo Medicine. 2015;12(1):234-38. DOI:10.1016/j.apme.2015.02.009. 
Барса М. М.

\section{ТРИВАЛІСЬ БЛОКАДИ ПЕРИФЕРИЧНИХ НЕРВОВИХ СПЛЕТЕНЬ РОЗЧИНОМ БУПІВАКАЇНУ НИЗЬКОЇ КОНЦЕНТРАЦІЇ ЗАЛЕЖНО ВІД ВИКОРИСТАНОГО АД'ЮВАНТА}

Рівненська обласна клінічна лікарня

\section{АКТУАЛЬНІСТЬ ПРОБЛЕМИ}

Пошук ідеального анестетика для периферичних нервових блокад, який би забезпечував адекватну анестезію під час оперативного втручання та тривалу аналгезію в післяопераційному знеболенні є однією з найбільш актуальних завдань в регіонарній анестезії та медицині болю.

Хронізація гострого післяопераційного болю, пізня мобілізація та реабілітація пацієнтів, розвиток тромбоемболічних ускладнень $є$ однією з найпоширеніших причин тривалого перебування пацієнта в стаціонарі та частоти розвитку післяопераційного делірію.

\section{META РОБОТИ}

Порівняти тривалість післяопераційної аналгезії після блокади периферичних нервових сплетень розчином бупівакаїну низької концентрації з дексаметезоном та розчину бупівакаїну низької концентрації з дексаметазоном та епінефрином, та вивчити можливість проведення ортопедичних оперативних втручань без використання наркотичних анальгетиків.

\section{МАТЕРІАЛИ ТА МЕТОДИ ДОСЛІДЖЕННЯ}

Пацієнти були розділені на дві групи (по 20 пацієнтів в кожній) в залежності від ад’юванта до місцевого анестетика:

1-ша група - хворі, блокаду яким було виконано розчином бупівакаїну $0,375 \%$ разом 3 дексаметазоном $0,02 \%$

2 -га група - хворі, блокаду яким було виконано розчином бупівакаїну $0,375 \%$ разом 3 дексаметазоном $0,02 \%$ та епінефрином 0,00018\% (Патент №133643)

Усім пацієнтам були проведені планові оперативні втручання на верхніх або нижніх кінцівках. Для знечулення оперативних втручань на верхній кінцівці виконувались надлючична або міждрибинчаста блокада плечового сплетення. Для знечулення оперативних втручань на нижній кінцівці виконувалась блокада стегнового нерву в паховій складці та блокада сідничного нерву субглютеарним доступом. Всі блокади виконувались під контролем апарату УЗД та за допомогою нейростимулятора. На блокаду кожного нерву або сплетення використано 20 мл розчину. У жодного з пацієнтів на було цукрового діабету або захворювань периферичної нервової системи.

Вродовж оперативного втручання було проведено седацію пропофолом $1 \%$ по цільовій концентрації 1,5 2,5 мкг/мл.

Здійснювався моніторинг показників артеріального тиску, частоти серцевих скорочень, пульсоксиметрія. Всі хворі були зігріті системою обігріву Nellcor Warm Touch.

У післяопераційному періоді пацієнти планово погодинно отримували нестероїдні протизапальні препарати.
Оцінювали тривалість блокади за допомогою проколу шкіри голкою. Кінець блокади - відчуття гострого болю. Оцінювали інтенсивність болю на 6-й, 1-й, 24-й та 36й годині після блокади за шкалою ВАШ.

Проводили статистику кількості використаного наркотичного анестетика в післяопераційному періоді.

РЕЗУЛЬТАТИ

Тривалість блокади в першій групі була достовірно меншою (18.05 \pm 3.56 vs $26.45 \pm 5.39$ годин).

Інтенсивність болю по ВАШ відрізнялась лише на 24 й годині.

Таблиця 1. Інтенсивність болю по ВАШ.

\begin{tabular}{c|c|c}
\hline \multirow{2}{*}{$\begin{array}{c}\text { Годин після } \\
\text { блокади }\end{array}$} & \multicolumn{2}{|c}{ Інтенсивність болю по ВАШ } \\
\cline { 2 - 3 } & Група №1 & Група №2 \\
\hline 6 & $0,3 \pm 0,47$ & $0,25 \pm 0,44$ \\
\hline 12 & $0,35 \pm 0,49$ & $0,3 \pm 047$ \\
\hline 24 & $3,55 \pm 0,67$ & $1,1 \pm 0,97$ \\
\hline 36 & $3,85 \pm 0,81$ & $3,65 \pm 0,75$ \\
\hline
\end{tabular}

Пацієнти жодної групи не вимагали введення наркотичних анальгетиків.

\section{висновки}

Епінефрин як ад’ювант до місцевого анестетика та дексаметазону периневрально збільшує тривалість блокади в середньому на 7 годин.

Використання епінефрину дозволяє ідентифікувати внутрішньосудинне введення місцевого анестетика і попередити розвиток токсичних реакцій.

Відмова від наркотичних анальгетиків в післяопераційному періоді дозволяє зменшити частоту респіраторних ускладнень, делірію та пришвидшити мобілізацію пацієнта.

\section{СПИСОК ЛІТЕРАТУРИ}

1. Dexamethasone as an adjuvant for peripheral nerve blockade: a randomised, triple-blinded crossover study in volunteers/Marhofe P, Columb M, Hopkins PM, Greher M, Marhofer D, Levi Bienzle MR, Zeitlinger M.// Br J Anaesth. 2019 Apr;122(4):525-53I.

2. Does preoperative risk for delirium moderate the effects of postoperative pain and opiate use on postoperative delirium? Jacqueline M. Leung MD MPH, Laura P Sands PhD Eunjung Lim, PhD, Tiffany L TSai, BA andSakura Kinjo, MD//Am J Geriat Psychiatry 2013 Oct: 21(10): 946-956

3. Клиническая Анестезиология книга первая/Дж. Эдвард МорганКлиническая Анестезиология книга первая/Дж. Эо

4. Functional recovery after knee arthroplasty with regional analgesia Functional recovery after knee arthroplasty with regional analgesia Osinsk, Thomas, Bekka, Samir; Regnaux, Jean-Philippe; Fletcher, Dominique; Martinez, Valeri European Journal of Anaesthesiology (EJA): June 2019 Volume 36 - Issue 6 - p 418-426 Патент №133643 Україна МПК 2019.01 А61К $9 / 08$ 2006.01A61K 31/00 А61Р 23/00 Розчин для пролонгованої блокади периферичних нервових сплетень, винахідник та власник Барса М.М. № 201900272 ,заявлено 10.01.2019, дійсно з 10.04.2019,Бюл. №7 
Березніцький Д.В., Лісецький В.А.

\title{
ЗНАЧЕННЯ ВНУТРІШНЬОЧЕРЕВНОГО ТИСКУ У ХВОРИХ ПІСЛЯ ОПЕРАЦІЙ НА ОРГАНАХ ЧЕРЕВНОÏ ПОРОЖНИНИ
}

\author{
Українська військово-медична академія, НВМКЦ «ГВКГ» МО України
}

\section{АКТУАЛЬНІСТЬ ПРОБЛЕМИ}

Синдром внутрішньочеревної гіпертензії (СВЧГ) діагностують у $20 \%$ хворих з терапевтичною і $30 \%$ пацієнтів 3 хірургічною патологією. Підвищення внутрішньочеревного тику (ВЧТ) призводить до порушення практично всіх життєво важливих функцій організму і є смертельною патологією, що вимагає своєчасної діагностики і негайного лікування. Летальність при його розвитку на тлі лікування досягає 42-68\%, а без лікування - 100\%. (Салахов Е.К. 2016 р.)

Адекватний моніторинг ВЧТ дозволяє своєчасно розпізнавати загрозливий для хворого рівень і застосовувати необхідні заходи, що попереджають виникнення і прогресування органних порушень. Проте, як свідчать дані опитування Європейської ради з інтенсивної терапії (ESICM) серед лікарів західної Свропи, за результатами якого встановлено, що понад 13\% респондентів взагалі не знайомі з терміном внутрішньочеревна гіпертензія і не мають уявлення про шкідливий вплив на організм підвищеного ВЧТ. Більше $60 \%$ лікарів не знайомі з причинами, патогенезом та методами діагностики і корекції цього синдрому і тільки $24 \%$ опитаних застосовують моніторинг ВЧТ. (Фофанов О.Д. 2010p.)

\section{META}

Визначити зв'язок підвищення внутрішньочеревного тиску з розвитком ускладнень після оперативних втручань у хворих з абдомінальною патологією.

\section{МАТЕРІАЛИ ТА МЕТОД ДОСЛІДЖЕННЯ}

Відбір матеріалу даної роботи був проведений серед пацієнтів відділення реанімації (ВРІT) для хірургічних хворих НВМКЦ «ГВКГ», тобто, моніторинг ВЧТ починався на $4-7$ день від початку хвороби. Проспективно проведено обстеження та вимірювання ВЧТ методом Крона на $1,3,5$ добу перебування у ВРІТ та ретроспективно проаналізовано дані карток стаціонарного хворого у 30 пацієнтів з абдомінальною патологією після оперативних втручань. Серед них було виділено три групи “ із захво- рюваннями печінки, шлунку та товстого кишечнику, кожна 3 яких містить 10 чоловік.

\section{РЕЗУЛЬТАТИ}

Серед пацієнтів із захворюваннями печінки ускладнення виникли у $80 \%$ (8 чол.), смертність $-40 \%$ (4 чол.). Середній показник ВЧТ серед хворих з ускладненнями склав 20,1 см вод. ст., а середня тривалість перебування у ВРІТ - 19,9 діб, натомість, у хворих без ускладнень середній ВЧТ - 13,8 см вод. ст., а середня тривалість перебування у ВРІТ - 4 доби.

В групі пацієнтів із захворюваннями товстого кишечнику ускладнення виникли у $30 \%$ (3 чол.), смертність $10 \%$ (1 чол.). Середній показник ВЧТ серед хворих 3 ускладненнями - 22,3 см вод. ст., середня тривалість перебування у ВРІТ склала 51,3 доби. У хворих без ускладнень середній ВЧТ - 14 см вод. ст., середня тривалість перебування у ВРIT - 2,7 доби.

Серед пацієнтів із захворюваннями шлунку ускладнення виникли у $20 \%$ (2 чол.), смертність - $0 \%$. Середній показник ВЧТ серед хворих з ускладненнями - 15,3 см вод. ст., середня тривалість перебування у ВРІТ - 9,5 діб. У пацієнтів без ускладнень середній ВЧТ “ 13,8 см вод. ст., а середня тривалість перебування у ВРІТ $-3,1$ доби.

\section{вИСНОВКИ}

Значне коливання ВЧТ (15 - 27 см вод. ст.) в ранньому післяопераційному періоді було виявлено лише у пацієнтів, котрі мали ускладнення (госпітальна пневмонія 3 вираженою дихальною недостатністю, гнійно-септичні ускладнення, гостра печінкова недостатність, шлунковокишкові кровотечі та мезентеріальний тромбоз) і високий ризик розвитку синдрому внутрішньочеревної гіпертензії, тому даний контингент хворих потребував проведення етіотропної антибактеріальної терапії, застосування НСПЗП та ліквідації вогнища інфекції. Натомість, у пацієнтів, котрі не мали ускладнень, показники ВЧТ тримались в межах 7,5 - 17 см вод. ст., тому виникає питання раціоналізації рутинного моніторингу ВЧТ у всіх категорій пацієнтів що перебувають у BPIT.

УДК: 616-001.1/36-005.1-35-73-085-092.18-092.6:[615.035.1/9+615.272.2]

Білецький О.В.

\section{ЕЛЕКТРОЛІТНИЙ СКЛАД ПЛАЗМИ КРОВІ В УМОВАХ МАГНЕЗІАЛЬНОЇ ТЕРАПІЇ У ПАЦІЄНТІВ В СТАНІ ТРАВМАТИЧНОГО ШОКУ НА ТЛІ ПОЛІТРАВМИ}

Харківська медична академія післядипломної освіти, м. Харків, Україна

\section{АКТУАЛЬНІСТЬ ПРОБЛЕМИ}

Магнезіальна терапія в теперішній час все ширше застосовується з метою захисту міокарда і головного мозку при тяжкому стресі, а також для покращення періоду введення в наркоз, забезпечуючи стабільність гемодинаміки при інтубації трахеї та міорелаксацію. Гіпертонічний розчин магнію сульфату застосовують 3 метою прискорення усунення дефіциту об'єму циркулюючої крові (ОЦК) при крововтраті замість гіпертонічного розчину натрію хлориду. Проте результатів вивчення електролітного складу плазми крові в умовах зазначеної магнезіальної терапії бракує.

\section{МЕТОЮ НАШОГО ДОСЛІДЖЕННЯ}

було визначення концентрації основних електролітів в плазмі крові в процесі застосування гіпертонічного розчину магнію сульфату у постраждалих на політравму, які перебували в стані гіповолемічного шоку.

\section{МАТЕРІАЛИ I МЕТОДИ}

До дослідження включено 24 хворих з політравмою, у віці від 18 до 65 років, які надходили до операційної в ургентному порядку в стані гіповолемічного травматичного шоку. Для всіх хворих забезпечено інтенсивну терапії згідно із змістом протоколів, затверджених МО3 України. 
Проте в основної групи хворих $(\mathrm{n}=12)$ в складі рідинної ресусцитації застосовувався гіпертонічний розчин магнію сульфату в фізіологічному розчині із розрахунку $(0,35 \pm 0,05)$ мл/кг (одна ампула $25 \%$ розчину сірчанокислої магнезії об'ємом 10 мл на 200 мл фізіологічного розчину) Контролювали вміст в крові іонів натрію, калію, кальцію, магнію та хлоридів, показники гемодинаміки, темп діурезу.

\section{РЕЗУЛЬТАТИ}

Агресивне введення до організму магнію та сульфату призводило до витіснення з плазми крові інших іонів. Відповідно позитивно заряджений магній сприяв достовірному зменшенню вмісту в плазмі крові іонів натрію та калію, а сульфати сприяли зменшенню вмісту хлоридів. Отже вміст натрію та хлоридів зменшувався, навіть на фоні інфузії фізіологічного розчину. Проте небезпеки не було. Цікаво, що вміст кальцію в плазмі крові не зменшу- вався. Терапія гіпертонічним розчином магнію сульфату сприяла прискоренню відновлення ефективного ОЦК, а разом, зростанню показників артеріального тиску та перфузійного індексу. Негативного впливу на функцію нирок не констатовано. Навпаки, прискорення відновлення ОЦК та системного артеріального тиску асоціювалося із зростанням темпу діурезу. Досягнення небезпечної концентрації магнію в плазмі крові (4 мМоль/л і більше) не відбувалося. Вміст магнію в плазмі починав відповідати нормальним показникам (біля 1,0 мМоль/л) через 24 години від початку магнезіальної терапії.

\section{ВИСНОВОК}

Включення до складу рідинної ресусцитації у хворих в стані травматичного шоку інфузії гіпертонічного розчину магнію сульфату в фізіологічному розчині не сприяе виникненню небезпечних для життя пацієнтів зсувів електролітного складу плазми крові.

\section{ОСОБЛИВОСТІ АНЕСТЕЗІОЛОГІЧНОГО ЗАБЕЗПЕЧЕННЯ СТОМАТОЛОГІЧНИХ ПРОЦЕДУР В ЗОНІ ОПЕРАЦІЇ ОБ'ЄДНАНИХ СИЛ (ООС)}

Українська асоціація седації та анестезії в стоматології (УАСАС), Центр стоматологічної імплантації та протезування «ММ»

\section{вступ}

96\% воїнів, що перебувають в зоні ООС на сході України, потребують санації ротової порожнини. Актуальним залишається питання стоматологічної реабілітації протезування воїнів ООС, де проведення імплантації потребує анестезіологічного супроводу. УАСАС, «ММ», «ТриЗуб Дентал» на благодійних засадах підтримала акцію лікування в пересувних і стаціонарних стоматологічних кабінетах в зоні ОOC.

\section{META}

організувати адекватний анестезіологічний супровід при хірургічному стоматологічному лікуванні, дослідити особливості перебігу анальгоседації та запобігти розвитку невідкладних станів.

\section{МАТЕРІАЛИ І МЕТОДИ}

Безпосередньо в зоні ООС розміщений базовий табір «Домік», обладнаний стаціонарним стоматологічним кабінетом на 2 робочих місця, у військових підрозділах працюють 4 пересувних та 3 стаціонарних стоматкабінети. Щодня отримують фахову стоматологічну допомогу 2540 бійців. За 4 роки проліковано біля 15000 воїнів та 500 місцевих жителів, запротезовано понад 1000 бійців. У 2017-19 р. волонтерами стоматологами центру «ММ» у стаціонарному стоматкабінеті в Карлівці в зоні ООС проліковано 220 пацієнтів (175 чоловіків, 45 жінок). Проте при проведенні імплантації у 2 пацієнтів спостерігалась втрата свідомості, у 1 з судомами, в $30 \%$ - виражений страх, в 15\% підвищення АТ. Тому вирішено залучити анестезіолога для забезпечення комфортного лікування воїнів. Анестезіологами було здійснено 5 виїздів. При наявності анестезіолога в складі хірургічної стоматологічної бригади проведено імплантацію під анальгоседацією 63 пацієнтам (ASA I-II, 14 жінок, 49 чоловіків), 8 супроводів анестезіолога 3 монітором життєвих функцій, контролем загального стану. Окрім монітору життєвих функцій було налагоджено подачу кисню через носові канюлі від концентратора кисню. Монітор та концентратор подаровано УАСАС. Анальгоседація: в/в пропофол, декскетопрофен; місцева анестезія; симптоматичні засоби.

\section{РЕЗУЛЬТАТИ ДОСЛІДЖЕНЬ}

Анальгоседація проводилась у 52 пацієнтів через великий об'єм стоматлікування, 6 - непереборний страх, 5 - виражений блювотний рефлекс. Під час анальгоседацій ускладнень не було. Середня тривалість седації 90 хв, лікування 78 хв. Пацієнти відмічали позитивний настрій, відсутність болю після стоматологічного втручання під анальгоседацією. 3220 пацієнтів фармакологічного заспокоєння потребували 77 (35\%) пацієнтів, корекції АТ - 42 (19\%), гемостатиків - 13 (6\%), в/в знеболення - 64 (24\%) пацієнтів, за що відповідав анестезіолог. Необхідна достатня кваліфікація анестезіолога, вміння працювати в команді, адже в даних умовах немає комфортних умов праці, передопераційного обстеження пацієнта, тощо.

\section{вИСновки}

Анестезіологічний супровід тривалих стоматологічних операцій в зоні ООС дозволяє надати якісну стоматологічну допомогу воїнам, попередити розвиток ускладнень. Для цього необхідні: достатня кваліфікація анестезіолога, медикаменти та обладнання для проведення анальгоседації та ліквідації невідкладних станів, концентратор кисню, монітор життєвих функцій організму. 


\section{Бітчук М.Д., КУдінова О.В., Баусов Є.О. \\ СПОСТЕРЕЖЕННЯ ФЕНОМЕНА МІОКАРДІАЛЬНОГО СТАНІНГА СЕРЕД ХВОРИХ НЕВРОЛОГІЧНОГО ПРОФІЛЮ}

Удк: 616.1:[617+616-001/002/008/009-06/07-092.6

Харківський національний медичний університет

\section{АКТУАЛЬНІСТЬ ПРОБЛЕМИ}

Ознаки міокардіального станінга все частіше констатують серед хворих з мозковим інсультом (МI) та тяжкою черепно-мозковою травмою (ТЧМТ). Патологічні зміни ЕКГ знаходять у 60-90\% хворих на МІ. Пригнічення помпової функції серця констатують як на тлі геморагічного, так й ішемічного MI, а також у постраждалих на ТЧМТ.

\section{META РОБОТИ}

Виявлення випадків проявів міокардіального станінга серед пацієнтів неврологічного та нейрохірургічних відділень міської багатопрофільної лікарні швидкої допомоги та оцінка їх перебігу.

\section{МАТЕРІАЛИ I МЕТОДИ}

Пацієнти з ішемічним (n=7), геморагічним MI (n=12) та 3 ТЧМТ $(\mathrm{n}=9)$, яким надавалася допомога у ВІТ багатопрофільної лікарні екстреної медичної допомоги. Порушення помпової функції серця виявляли за допомогою трансторакального ультразвукового дослідження (ТУЗД) з додатковою об'єктивізацією стану центральної гемодинаміки за допомогою тетраполярної грудної реографії; артеріотензометрія; визначення центрального венозного тиску (ЦВТ); фотоплетизмометрії; ЕКГ-дослідження в 12 відведеннях та моніторинг; визначення вмісту серцевого тропоніну I в плазмі крові; оцінка неврологічного статусу.

\section{РЕЗУЛЬТАТИ}

Всі пацієнти, в яких було виявлено ознаки міокардіального станінга мали порушення функції свідомості з іiі депресією та оцінкою за шкалою ком Глазго < 11 балів. Підозра в наявності зменшення продуктивності серця виникала при появі артеріальної гіпотензії із зростанням ЦВТ $\geq 80$ мм $\mathrm{H}_{2} \mathrm{O}$. У частки хворих систолічний артеріальний тиск міг сягати 110-120 мм Hg, проте визначалися порушення об'ємного периферичного капілярного кровообігу із зменшенням показника перфузійного індексу до $1 \%$ й менше. Перфузійний індекс був зменшеним у всіх хворих. При ТУЗД знаходили ланки міокардіальної гіпокінезії. Фракція викиду могла перевищувати $50 \%$, проте за даними тетраполярної грудної реографії ударний об’ $є м$ серця не сягав 1мл / кг маси тіла. Патологія ЕКГ була неспецифічною та полягала у наявності двозначних змін сегмента ST. Вони мали місце у всіх таких хворих, без виключення. Гострих вогнищевих змін не знаходили. Вміст тропоніну I в плазмі крові перевищував референтний інтервал (в нормі до 0,06 нг/мл), проте значного зростання концентрації (до 0,2 нг/мл і більше) не визначалося. Позитивна динаміка мала місце на фоні створення тривалої нейровегетативної блокади за допомогою тіопенталу натрію та діазепаму в умовах ШВЛ. Потреба в застосуванні допаміну не перевищила 24 годин. Після цих заходів інтенсивної терапії мала місце позитивна динаміка ЕКГ.

\section{ВИСновок}

Феномен міокардіального станінга виявляється не тільки у хворих з провідною патологією коронарних судин. Його розвиток цілком можливий у пацієнтів неврологічного та нейрохірургічного профілю, що відбиває термін «неврогенний станований міокард».

УДК: 616.8-009.836 : 617-089

\section{Бодулєв О.Ю., Шкурупій Д.А. \\ РОЗПОВСЮДЖЕНІСТЬ ТА ФАКТОРИ РИЗИКУ ПІСЛЯОПЕРАЦІЙНОÏ ІНСОМНІЇ}

Українська медична стоматологічна академія. м. Полтава, Україна

\section{АКТУАЛЬНІСТЬ ПРОБЛЕМИ}

У сучасних умовах до анестезіологічного забезпечення висунуті вимоги не лише щодо підтримки вітальних функцій, але й забезпечення комфорту періопераційного періоду [1]. Однією з невід'ємних частин цього комфорту є сон, який бере безпосередню участь у процесах фізіологічного відновлення після операційної травми. Не дивлячись на загальносвітові тренди українська анестезіологічна спільнота приділяє недостатньо уваги післяопераційній інсомнії.

\section{META РОБОТИ}

Аналіз поширеності післяопераційної інсомнії та її зв'язок із методом анестезіологічного забезпечення.

\section{МАТЕРІАЛИ ТА МЕТОДИ}

У проспективному когортному дослідженні взяло участь 200 пацієнтів, яким проведені ортопедичні та хірургічні втручання. Групи були розділені за методом анестезіологічного забезпечення. У групу загальної анестезії (3А) увійшов 81 пацієнт, у групу спинномозкової (CMA) - 119. Групи були репрезентативні за віковим та гендерним складом. Оцінка за ASA склала $2,59(2,40 ; 2,79)$ для групи 3А, та $3,08(2,90 ; 3,26)$ для СМА. Час операції склав 104,01 хв. $(116,77 ; 91,26)$ та 78,28 хв. $(84,47 ; 72,08)$ відповідно. Очікуваний рівень болю [2] склав 4,95 $(5,44$; $4,46)$ для 3А та $6,03(6,40 ; 5,63)$ для СМА.

\section{РЕЗУЛЬТАТИ}

Частота розвитку післяопераційної інсомнії у групі 3А склала 76,54\%, серед яких випадків легкого ступеню $44,4 \%$, середньотяжких $-19,75 \%$ та тяжких $-12,35 \%$. У групі СМА - 69,75\%, серед яких випадків легкого ступеню $-40,3 \%$, середньотяжких $-17,65 \%$ та тяжких $-11,76 \%$ Різниця між групами була статистично недостовірною. В обох групах виявлено помірну кореляцію між частотою інсомнії та вираженістю післяопераційного болю $(\mathrm{r}=0,53)$, що відповідає літературним даним [3, 4]. Також спостерігалась кореляція помірної сили 3 рівнем тривожності за госпітальною шкалою тривоги та депресії $(\mathrm{r}=0,64)$.

\section{вИСНОВКИ}

Інсомнія $\epsilon$ широко розповсюдженим ускладненням післяопераційного періоду. Фактори ії розвитку досліджені недостатньо та потребують подальшого вивчення. 
Особливої уваги потребує уточнення ролі виду анестезіологічного забезпечення в формуванні інсомнії.

\section{СПИСОК ЛІТЕРАТУРИ}

1. Bani Younis $M$, Hayajneh $F$, Batiha AM. Measurement and Nonpharmacologic Management of Sleep Disturbance in the Intensive Care Units: A Literature Review. Crit Care Nurs Q. 2019 Jan/Mar;42(1):75-80.
2. Jaffe A. Richard; Samuels I. Stanley. Anesthesiologist's Manual of Surgical Procedures, 5 ed. Lippincott Williams \& Wilkins, 2014. pp. 2626

3. Su X, Wang DX. Improve postoperative sleep: what can we do? Curr Opin Anaesthesiol. $2018 \mathrm{Feb} ; 31(1): 83-88$.

4. Chen CR, Zheng JW, Meng B, Lu B, Zhai XJ. Comparison of effects of two anesthesia methods on the first night sleepquality in middle-aged and elderly patients undergoing surgery for lower extremity varicose vein Zhonghua Yi Xue Za Zhi. 2018 Dec 11;98(46):3773-3777.

УДК: 616.831.9-002-053.2/6

Георгіяни М.A., Корсунов В.А.

\section{ГІПЕРТЕРМІЯ У ДІТЕЙ. ПОГЛЯД 3 ПОЗИЦІї ІНТЕНСИВНОЇ ТЕРАПІЇ}

\section{АКТУАЛЬНІСТЬ}

Захворювання у дітей раннього віку, які супроводжуються гарячкою, зазвичай свідчать про наявність інфекції і викликають занепокоєння. Захворювання, що супроводжуються гарячкою, дуже часто зустрічається у маленьких дітей. Лихоманка, ймовірно, є найпоширенішою причиною звернення до лікаря, та другим 3 найбільш частих приводів надходження дітей до лікарні. Незважаючи на досягнення в галузі охорони здоров'я, інфекції залишаються провідними причина смерті у дітей віком до 5 років, отже $є$ нагальною проблема раннього виявлення життєзагрожуючих інфекцій серед дітей з лихоманкою.

\section{META}

Представити огляд сучасних принципів обстеження дітей $з$ лихоманкою та напрямків іiі лікування 3 позиції інтенсивної терапії.

\section{МАТЕРІАЛИ ТА МЕТОДИ}

Огляд провідних джерел та рекомендацій авторитетних медичних спільнот виданих англійською мовою за останні 5 років щодо діагностичних та лікувальних напрямків у дитини $з$ лихоманкою.

\section{РЕЗУЛЬТАТИ}

Аналіз широкого кола оглядів та гайдланів щодо тактики обстеження, спостереження та терапії дитини з лихоманкою свідчить про суттєві відмінності загальновідомих рекомендацій та вітчизняної практики лікувальних установ. Головною метою провідних рекомендацій є виокремлення пацієнтів 3 високим ризиком здоров'ю та життю бактеріальних інфекцій та сепсису. Саме для цього запропоновано кілька систем бальної оцінки наявного ризику тяжкого захворювання для доношених та недоношених немовлят (Йельскі, Рочестерські, Національного інституту здоров'я). Особливу увагу приділяють дитині 3 лихоманкою без наявного інфекційного вогнища (fever without source). Це клінічне визначення, нажаль, не знайшло місце у вітчизняній практиці та навчальних програмах. Крім цього пропонуються протоколи лабораторного обстеження дитини з лихоманкою, залежно від віку та терміну гестації, критерії для госпіталізації та початку антибактеріальної терапії.

\section{висновки}

Лихоманка у дітей, здебільш раннього віку, у тих випадках, коли не супроводжується іншими клінічними ознаками та дитина не отримала профілактичних щеплень від менінгококу, пневмококу та гемофільної палички, нерідко є ознакою життезагрожуючої інфекці (менінгіту, пневмонії, інфекції сечовивідних шляхів, сепсису тощо) і потребує ретельної клініко-лабораторної оцінки, спостереження та лікування, яке у випадку сепсису та розладів вітальних функцій має проводитися у відділеннях інтенсивної терапії.

\section{СПИСОК ЛІТЕРАТУРИ}

1. Management of fever in critically ill patients with infection / M. Egi, S. Makino, S. Mizobuchi // J Emerg Crit Care Med. - 2018. - Vol. 2. - P.10 2. 2016 Update of the Italian Pediatric Society Guidelines for Management of Fever in Children E. Chappini E. Venturini, G. Remaschi, N. Principi, R. Longhi, P-A. Tovo, P. Becherucci, F. Bonsignori, S. Esposito, F. Festini, L. Galli, B. Lucchesi, A. Mugelli, G. L. Marseglia, M.de Martino // J Pediatr. - 2017. - Vol.180. - P.177-183.

УДК: 616.33.-008.3.-053

\section{Георгіяни М.А., Корсунов В.А., Раскова Т.Ю., Зюбан Д.Р. ПІСЛЯОПЕРАЦІЙНА НУДОТА ТА БЛЮВАННЯ У ДІТЕЙ. ПРОГНОЗУВАННЯ ТА НАПРЯМКИ ПРОФІЛАКТИКИ}

\section{АКТУАЛЬНІСТЬ}

Післяопераційна нудота та блювання (ПОНБ) є розповсюдженим ускладненням загальної анестезії. У дітей ПОНБ зустрічається частіше, ніж у дорослих та призводить до широкого кола ускладнень. Серед факторів ризику ПОНБ $є$ періопераційне голодування, тривалість хірургічного втручання, та його окремі напрямки (хірургія косоокості, аденотонзілектомія, отопластика, орхопексія, втручання на статевому члені). Збільшують частоту ПОНБ опіоїди та закис азоту, натомість відмічається зменшення частоти ПОНБ при використанні більших об'ємів інфузійної терапії (IT). Зважаючи на те, що одним з чинників ПОНБ є нестача вуглеводів та кетоацидоз, ми припустили доцільність додання до IT розчину ксилітолу «Ксилат», який має значну антикетогенну дію.

\section{META}

Знизити частоту ПОНБ та кетоацидозу у дітей з оперативними втручаннями 3 приводу захворювань сечостатевої системи, шляхом модифікації складу IT періопераційного періоду.

\section{МАТЕРІАЛИ ТА МЕТОДИ}

Дослідження проводилося в 2016-2018 pp. у Харківському обласному нефро-урологічному центрі ім. проф. B.I. Шаповала. До нього увійшло 173 хлопчика віком

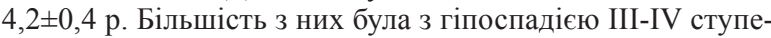
ня, у інших показанням для втручання були перекручення та водянка яєчка, крипторхізм. Премедикація включала промедол, атропін, димедрол, діазепам. Хірургічні втручання проводились під в/в анестезію пропофолом та 
кетаміном. Упродовж хірургічного втручання та у післяопераційному періоді здійснювалася IT. Відповідно до іiі складу всіх хворих було розподілено на дві групи. Хворі групи $1(\mathrm{n}=89)$ отримували IT глюкозо-сольовими розчинами. Хворі групи $2(\mathrm{n}=84)$ крім глюкозо сольових розчинів отримували Ксилат дозою 20 мл/кг маси тіла. Протягом 2-х діб періопераційного періоду визначали рівень глікемії та кетонурії, скарги на нудоту та епізоди блювання.

\section{РЕЗУЛЬТАТИ}

У першу післяопераційну добу об'єм IT у групах не відрізнявся $(\mathrm{p}>0,05)$. За рівнем глікемії відмінностей між пацієнтами 1 та 2 груп не було (p>0,05). Кетонурія у групі 1 спостерігалась у $31(34,8 \%)$ хворих. У групі 2 випадків кетонурії не було, OR 0,01, 95\% ДI [0,0008 - 0,2112] $(\mathrm{p}=0,0024)$. У групі 1 протягом першої доби після анестезії скарги на нудоту зареєстровані у $42(47,1 \%)$ хворих, а у групі 2 - у 3 хворих (3,5\%), OR 0,06, 95\% ДІ [0,017 $0,202](\mathrm{p}<0,0001)$. У групі 1 блювання спостерігалось у $30(33,7 \%)$ хворих, у групі 2 - у 3 хворих, OR $0,05,95 \%$ ДІ [0,012 - 0,230], (p=0,0001).

\section{висновки}

Використання IT, яка включала «Ксилат» у дітей, яким проводилися оперативні втручання на органах сечостатевої системи, на відміну від IT глюкозо-сольовими розчинами, знижує ризик кетоацидозу, епізодів нудоти та блювання.

\section{СПИСОК ЛІТЕРАТУРИ}

1. Guidelines on the Prevention of Post-operative Vomiting in Children Guidelines on the Prevention of Post-operative Vomiling in Children Pediatric Anesthetists' of Great Britain \& Ireland - 2016. - $36 \mathrm{p}$.

Георгіяни М.А., Корсунов В.А., Скорик В.С.

УДК: 616.24-002-02-089

\section{СУЧАСНА АНТИБАКТЕРІАЛЬНА ТЕРАПІЯ ВАП. ЯКИМ Є ВІКНО МОЖЛИВОСТЕЙ}

\section{АКТУАЛЬНІСТЬ}

Вентилятор-асоційовані інфекції респіраторного тракту, до яких відносяться вентилятор-асоційований трахеїт (BАT) та вентилятор-асоційована пневмонія (ВАП), є поширеними та тяжкими ускладненнями ШВЛ. Вважається, що до ВАП відноситься $80 \%$ всіх випадків госпітальних пневмоній, а ризик іiі розвитку при тривалій ШВЛ зростає у 21 раз. Летальність у хворих, які знаходяться на інвазивній респіраторній підтримці із ВАП, сягає 57-70\% і зростає вдвічі, порівняно з пацієнтами без ВАП. Головними чинниками збільшення летальності у хворих на ВАП $\epsilon$ поглиблення дихальної недостатності та висока частка антибіотикорезистентних збудників.

\section{META}

Представити огляд сучасних та перспективних можливостей емпіричної та цілеспрямованої антибактеріальної терапії ВАП та ВАТ, охарактеризувати основні обмеження для ії проведення

\section{МАТЕРІАЛИ ТА МЕТОДИ}

Огляд провідних джерел та рекомендацій авторитетних медичних спільнот виданих англійською мовою за останні 5 років щодо лікування ВАП та ВАТ.

\section{РЕЗУЛЬТАТИ}

Аналіз літератури свідчить про незупинне зростання резистентності грам-негативних збудників ВАП та ВАТ до найважливіших груп антибіотиків резерву. Найбільш проблемними $є$ неферментуючи бактерії та ентеробактерії, серед яких зустрічаються полідрагрезистентні та екстен- сівдрагрезистентні ізоляти. Найбільше значення для терапії зберігають захищені антисиньогнійні пеніциліни та цефалоспорини, карбапенеми, респіраторні фторхінолони, поліміксини, аміноглікозиди та тайгециклін. По відношенню до стійких грам-позитивних значно надійнішим $є$ використання доступних в Україні глікопептидів, оксазалідинонів, цефалоспоринів V генерації та тайгецикліну. Розвивається кілька напрямків модифікації шляхів та технологій введення антибактеріальних засобів, а саме інгаляційний шлях та пролонгована інфузія, які, ймовірно, певним чином здатні частково долати резистентність. Кілька перспективних представників тетрациклінів, карбапенемів та цефалоспоринів активно досліджуються у клінічних умовах, але допоки не зареєстровані в Україні.

ВИСНОВКИ

Інтенсивна терапія ВАП є складною проблемою сучасної медицини, яка потребує глибокого вивчення та розробки нових напрямків ії вирішення. Запорукою покращення результатів лікування $\epsilon$ локальний мікробіологічний моніторинг у ВIT.

\section{СПИСОК ЛІТЕРАТУРИ}

1. IDSA Guideline Management of Adults With Hospital-acquired and Ventilator-associated Pneumonia: 2016 Clinical Practice Guidelines by the Infectious Diseases Society of America and the American Thoracic Society / A. Kalil, M. Metersky, M. Klompas [et al.] // Clinical Infectiouse Diseases - 2016. - Vol. 63. - P. 61-111.

2. The use of inhaled antibiotic therapy in the treatment of ventilatorassociated pneumonia and tracheobronchitis: a systematic review C. Russell, M. Shiroishi, E. Siantz [et al.] // BMC Pulmonary Medicine. - 2016. - Vol. 16. - DOI 10.1186/s12890-016-0202-8.

Георгіяни М.А., Корсунов В.А., Кухар Д.І., Пороша Н.С., Столяров К.Є., Зубко В.О.

\section{КРИТИЧНА ІНТРАКРАНІАЛЬНА ГІПЕРТЕНЗІЯ У ДІТЕЙ. МОЖЛИВОСТІ НЕІНВАЗИВНОЇ ОЦІНКИ ТА АКТУАЛЬНІ ПРИНЦИПИ КОРЕКЦІЇ}

\section{АКТУАЛЬНІСТЬ}

Підвищення внутрішньочерепного тиску (ICP) або внутрішньочерепна гіпертензія (ВЧГ) є розповсюдженим неврологічним ускладненням у дітей 3 критичними станами. Провідними чинниками ВЧГ є черепно-мозкова травма, гіпоксичне ушкодження ЦНС, пухлини, розлади моз- кового кровообігу та нейроінфекції. Універсальними наслідками ВЧГ є зниження церебрального перфузійного тиску (СРР), цербральна ішемія, синдроми уклинення, які зумовлюють вторинне ушкодження мозку та $\epsilon$ визначними факторами формування несприятливих неврологічних 
виходів. Зростання ICP до 20-25 мм.рт.ст. вважається критичним та потребує проведення інтенсивної терапії (IT).

\section{META}

Покращити результати IT критичної інтракраніальної гіпертензії у дітей шляхом впровадження неінвазивної оцінки внутрішньочерепного та церебрального перфузійного тисків та цілеспрямованої їх корекції гіпертонічними розчинами у межах доктрини Рознера.

\section{МАТЕРІАЛИ ТА МЕТОДИ}

Під нашим спостереженням протягом 2007-2019 рр. знаходилося 60 дітей середнім віком 75,1土9,2 міс, які надходили до ВІТ КНП Харківська обласна дитяча інфекційна клінічна лікарня з нейроінфекціями (менінгіти, $\mathrm{n}=25$ та енцефаліти, $\mathrm{n}=35$ ) та наявністю ВЧГ. Середня оцінка за педіатричною шкалою ком Glasgow становила $9,1 \pm 0,4$ балів. Забезпечувалося моніторинг ЕКГ, ЧСС, САТ, пульсоксиметрії. Визначали гематокрит, загальний білок, креатинін, лактат, глюкозу та електроліти $\left(\mathrm{Na}^{+}, \mathrm{K}^{+}, \mathrm{Cl}^{-}, \mathrm{Ca}^{++}\right)$ сироватки. Всім пацієнтам проводилося ультразвукове дуплексне сканування кровоплину у середньомозкових артеріях із автоматичним розрахунком швидкостей кровоплину, пульсаційного та резистивного індексів та неінва- зивних показників ICP та CPP за Bellfort et al. Методом ехосоноскопії вимірювалися товщина зорових нервів. IT ВЧГ проводилася шляхом застосування седації, інтубації трахеї та респіраторної підтримки, протисудомної та антипіретичної терапії, інфузії гіпертонічних розчинів, використання симпатоміметиків для забезпечення цільових показників СРР та інфузії барбітуратів.

\section{РЕЗУЛЬТАТИ}

До початку терапії середній показник ICP становив $31,3 \pm 0,3$ мм рт.ст.

У більшості хворих використаний комплекс IT сприяв відновленню ефективної церебральної циркуляції, корекції ВЧГ та поступовому відновленню свідомості і редукції неврологічного дефіциту. Померло 5 (8,3\%) хворих. Значний неврологічний дефіцит у катамнезі виявився у 4 (7,3\%) хворих з числа одужавших.

\section{висновки}

Запропонований комплекс інтенсивної терапії критичної інтракраніальної гіпертензії сприяє покращенню результатів лікування хворих на нейроінфекції.

СПИСОК ЛІТЕРАТУРИ

1. Asiedua D. A Review of Non-Invasive Methods of Monitoring Intracranial Pressure / D. Asiedua, K. Leeb, G. Millsa [et al.] // J Intracranial Pressure D. Asiedua, $K$.

Голяніщев М.О., Лисенко В.Й., Лисиця В.Т. ${ }^{2}$

\section{ТЕХНІЧНІ ПЕРЕДУМОВИ УСПІШНОСТІ ВИКОНАННЯ СИМУЛЯЦІЙНОЇ СПРОБИ ДОСЯГНЕННЯ ЦІЛЬОВОЇ ТОЧКИ ЗА ДОПОМОГОЮ ПРИСТРОЮ-СИМУЛЯТОРА ДЛЯ PEґ'ОНАРНИХ АНЕСТЕЗІЙ}

'Харківська медична академія післядипломної освіти, Харків, Україна; anesthesiology@med.edu.uа ${ }^{2}$ Харківський національний університет імені В.Н.Каразіна

\section{АКУТАЛЬНІСТЬ}

Мануальні навички лікаря-анестезіолога залишаються головним дієвим впливом, що дозволяє відтворити знання лікаря, інноваційні переваги нових технічних засобів та лікарських препаратів. Тому, особливо в наступний час, компетентнісно-орієнтований принцип навчання лікаріванестезіологів залишається актуальним.

3 метою впровадження симуляційного етапу засвоєння компетенцій по виконанню регіонарних анестезій колективом винахідників (Голяніщев М.О., Лисиця В.Т., Крючков В.В.) розроблений та отриманий патент на корисну модель №134147 на пристрій-симулятор для відпрацювання регіонарних анестезій. Під час сеансу навчання слухачі відтворювали маніпуляцію пункційного досягнення цільової точки параневрального простору, що є наріжним етапом будь-яких регіонарних блокад та пункційних маніпуляцій.

\section{МЕТА ДОСЛІДЖЕННЯ}

Метою нашого дослідження було визначення технічних передумов успішності досягнення слухачами цільової точки 3 використанням розробленого пристрою-симулятора.

\section{МЕТОДИ ТА МАТЕРІАЛИ ДОСЛІДЖЕННЯ}

Дослідження проведено на групі з 42 слухачів (лікаріінтерни зі спеціальності «Анестезіологія» першого року навчання, лікарі циклу спеціалізація «Анестезіологія»), яким після стандартного інструктажу запропоновано за допомогою розробленого пристрою-симулятору та голки Stimuplex A (довжина 100мм) виконати спроби досягнення цільової точки «симуляційного» параневрального простору. Визначалися два варіанти результатів: попадання на $100 \%$ - кінець голки зупинявся на дистанції 2-0 мм від по- верхн1 макета нерва; помилка - кінець голки зупинявся на дистанції більше 2 мм від поверхні макета нерву, або голка проходила глибше верхнього краю поверхні макета нерва.

\section{РЕЗУЛЬТАТИ ТА ОБГОВОРЕННЯ}

Використання симуляційного навчання підвищило рівень мотивації до опанування технікою регіонарної анестезії. Цьому спонукали віддалені від хворого умови опанування мануальної навички, можливість тактильного та зорово-просторового запам'ятовування окремих етапів виконання головного етапу пункційної маніпуляції - досягнення цільової точки. За результатами дослідження визначено, що кількість спроб з помилкою суттєво підвищувалась при наступних умовах: глибина залягання макета цільового утвору (напр.: нерв, нервове сплетіння) більше 50мм, кут підведення голки відрізняється від 90 градусів відносно цільового утвору більше ніж на 15 градусів.

\section{висновки}

Кількість помилок при виконанні регіонарних методик анестезії новачками суттєво збільшується при маніпуляції голкою на глибинах більше 50мм та співвідношення вісі голки та умовної вісі цільового утвору більше ніж 15 градусів; помилка виконання спроби може бути обумовлена бажанням недопущення надлишкового пошкодження тканин уявного пацієнта; значення рівня компетентності та додаткової орієнтуючої інформації на точність виконання пункційної маніпуляції потребує подальшого дослідження.

\section{СПИСОК ЛІТЕРАТУРИ}

1. Lahham S. Procedural simulation: medical student preference and value of three task trainers for ultrasound guided regional anesthesia / S. Lahham, T. Smith, J. Baker, A. Purdy and coathors. / 
World J. Emerg. Med. - 2017. - Vol. 8(Suppl. 4). - P.287-291.; doi 10.5847/wjem.j.1920-8642.2017.04.007

2. Stone L. Low cost simulation training in anaesthesia / L. Stone, A. Hellewell // Update in Anaesthesia. - 2014. - Vol. (Suppl. 29). - P.44-46.
3. Loss of resistance: A randomised controlled trial assessing four lowfidelity epidural puncture simulators. Pedersen T.H., Meuli J. Plazikowski E. J., Buttenberg M., Kleine-Brueggeney $M$. and coauthor's // European Journal of Anaesthesiology. - 2017. - Vol. 34 (Suppl. 9) - P.602-608. doi: 10.1097/EJA.0000000000000640.

\section{Гриценко С.Н., Мизиненко И.В.}

\section{ТРОМБОЭМБОЛИИ ЛЕГОЧНОЙ АРТЕРИИ, ВАРИАНТЫ ИНТЕНСИВНОЙ ТЕРАПИИ}

\section{АКТУАЛЬНОСТЬ}

Тромбоэмболия легочных артерий (ТЭЛА) по праву считается одним из тяжелейших и катастрофически протекающих острых сосудистых заболеваний, сопровождающихся высокой летальностью. С легочной эмболией неизбежно сталкиваются представители как хирургических, так и терапевтических специальностей, поскольку она может возникнуть в самых различных клинических ситуациях. По данным Американской медицинской ассоциации, ежегодно в Соединенных Штатах отмечается до 650 тыс. случаев ТЭЛА, многие из которых заканчиваются смертью больного. Вместе с тем даже массивное эмболическое поражение легочных артерий прижизненно не диагностируется у $40-70 \%$ пациентов. Видимо, с этим связаны врачебные мифы, существование которых в наши дни не поддается рациональному объяснению. До сих пор бытует отношение к ТЭЛА как к фатальной неизбежности, предотвратить которую не представляется возможным. Полагают также, что она в большинстве случаев заканчивается молниеносной смертью больного. Подобное отношение ставит врача в позицию стороннего наблюдателя, от которого мало что зависит. Частота ТЭЛА в Украине около 50 тыс. в год, умирает более 10 тыс. больных $[1,2]$.

\section{ЦЕЛЬ ИССЛЕДОВАНИЯ}

Улучшить результаты интенсивной терапии ТЭЛА.

\section{МАТЕРИАЛ И МЕТОДЫ}

В исследование включены 276 больных с диагнозом ТЭЛА, которые получали лечение в отделении кардиореанимации Запорожской областной клинической больницы за период 2015-2018 годы.

Возраст от 23 до 90 лет, средний $-(60,7 \pm 13,6)$. Для верификации диагноза применяли ангиопульмографию (АПГ) и мультиспиральную компьютерную томографию с контрастным усилением (МСКТ). Степень нарушения проходимости ветвей легочной артерии оценивали ангиографическим индексом эмболии предложенный Miller G.A. при АПГ. При МСКТ использовали индекс эмболии, аналогичный индексу Miller с учетом количества, диаметра и степени нарушения проходимости сосудов. В соответствие с величиной индексов эмболии больные разделены на три группы: 1-15 баллов (немассивная ТЭЛА) - 35 больных, 16-21 балл (субмассивная ТЭЛА) - 80 больных, 22 и более (массивная ТЭЛА) - 161 больных.

\section{РЕЗУЛЬТАТЬ}

В зависимости от тяжести ТЭЛА дифференцированно подходили к выбору тромболитической терапии. При массивной и субмассивной ТЭЛА применяли альтеплазу или стрептокиназу, а при немассивной ТЭЛА - гепаринотерапию. В группе массивной ТЭЛА признаки острой легочной гипертензии (увеличение диаметра легочных артерий и смещение межжелудочковой перегородки влево) наблюдали у 56 больных (35\%), что требовало применения препаратов уменьшающих давление в легочном русле, в группе с субмассивной ТЭЛА легочную гипертензию наблюдали у $6 \%$ больных, в группе с немассивной ТЭЛА у $3 \%$. В связи с противопоказаниями к ТЛТ двум больным с массивной ТЭЛА выполняли открытую хирургическую легочную эмболэктомию. Позитивным считали снижение индексов эмболии до уровня менее 15 баллов или полный лизис тромбов, нормализацию артериального давления, показателя насыщение гемоглобина кислородом при дыхании воздухом, отсутствие одышки и снижение давления в легочной артерии до нормы или до уровня легочной гипертезии 1 ст.

Общая летальность при ТЭЛА составила $17.2 \%$, при тромболизисе менее $10 \%$.

\section{вЫвод}

Дифференцированный подход позволял выбрать метод лечения ТЭЛА в зависимости от тяжести заболевания: при массивной и субмассивной ТЭЛА обосновано применение ТЛТ, а при немассивной ТЭЛА - гепаринотерапия.

\section{ЛИТЕРАТУРА}

1. Тромбоэмболия легочной артерии / Ф.С. Глумчер, В.Г. Мишалов, А.С. Никоненко и др.; под ред. Ф.С. Глумчера, В.Г. Мишалова, А.С Никоненко, Б.М. Тодурова.- К.: Издатель Заславский А.Ю.,2016 524 c

2. Yazdani M., Lau C.T., Lempel J.K. [et al.]. Historical evolution of imaging techniques for the evaluation of pulmonary embolism: RSNA centennial article // RadioGraphics. 2015. Vol. 35. P. 1245-1262

УДК: 616-085.456-089.163-089.168-053.2

Давидова А.Г., Курочкін М.Ю., Капустін С.А.

\section{ПАРЕНТЕРАЛЬНЕ ХАРЧУВАННЯ У КОМПЛЕКСНІЙ ПЕРІОПЕРАТИВНІЙ ІНТЕНСИВНІЙ ТЕРАПІЇ У ДІТЕЙ}

\section{АКТУАЛЬНІСТЬ ПРОБЛЕМИ}

Метою парентерального харчування (ПХ) $є$ попередження або корекція нутритивного дефіциту у випадках, коли ентеральне харчування неможливе [1]. Відмінністю дитячого організму порівняно $з$ дорослими $є$ більша чутливість до недостатньої нутритивної підтримки у зв'язку з більш ви- сокою швидкістю метаболічних процесів, що робить більш актуальним забезпечення адекватного ПХ після великих хірургічних втручань, особливо у дітей раннього віку $[2,3]$. Однак, невірний розрахунок ПХ може призводити до ускладнень як при тривалому, так і при короткочасному його призначенні [4]. Тому призначення та динамічний моніторинг 
ПХ мають бути спрямовані на забезпечення ефективної та безпечної нутритивної підтримки [1].

\section{МАТЕРІАЛИ ТА МЕТОДИ}

Під спостереженням знаходились 100 дітей віком від 1,5 місяців до 17 років, що перенесли велике оперативне втручання на органах черевної порожнини. Групу спостереження склали пацієнти, що отримували парентеральне харчування у ранньому післяопераційному періоді (66 дітей), групу контроля - 34 дитини, що не отримували парентеральне харчування. Групи не відрізнялися за віком, статтю та тривалістю і об'ємом оперативного втручання. Усі діти отримували інфузійну, антибактеріальну терапію та адекватне знеболювання. Статистична обробка результатів проводилась за допомогою програми StatSoft 6.1.

\section{РЕЗУЛЬТАТИ}

При складанні індивідуальної схеми ПХ використовувалась розроблена нами програма розрахунку ПХ у Microsoft Excel. У групі дослідження був відмічений достовірний $(\mathrm{p}<0,05)$ приріст рівню білку плазми на 3-5 добу ПХ, на відміну від контрольної групи. При ПХ без інсуліну гіперглікемії вище 8 ммоль/л не відмічалося, в той час як при додаванні інсуліну у дітей до 1 року реєструвалась гіпоглікемія, що ліквідувалась після його відміни. Жодного випадку глюкозурії зареєстровано не було. Та- кож не відбувалося зростання рівню азотистих залишків у сироватці крові. У групі дослідження була відмічена більш рання поява перистальтики кишечнику у порівнянні з контрольною групою.

\section{висновки}

1. ПХ у ранньому післяопераційному періоді позитивно впливає на метаболічні та пластичні процеси в організмі та сприяє більш ранньому відновленню функції кишечнику.

2. Використання інсуліну при ПХ у дітей не показане.

3. Застосування ПХ після великих хірургічних втручань $\epsilon$ безпечним за умови дотримання коректного темпу інфузії, а також при правильному підборі виду ПХ та його складових.

СПИСОК ЛІТЕРАТУРИ.

1. Puntis J.W.L. ESPGHAN/ESPEN/ESPR/CSPEN guidelines on pediatric parenteral nutrition: Organisational aspects / J.W.L. Puntis, I. Hoisak, J. Ksiazyk // Clinical nutrition. - Vol. 37(6). - P. 2392-2400.

2. Mesotten D. ESPGHAN/ESPEN/ESPR/CSPEN guidelines on pediatric parenteral nutrition: Carbohydrates / D. Mesotten, $K$ Joosten, A. van Kempen et al. // Clinical nutrition. - 2018. - Vol. 37(6). - P. 2337-2343

3. Jimenez L. Timing of the initiation of parenteral nutrition in critically ill children / L. Jimenez, N.M. Mehta, C. Duggan // Cur Opin Clin Nutr Metab Care. - 2017. - Vol. 20(3). - P. 227-231.

4. Joosten K. ESPGHAN/ESPEN/ESPR/CSPEN guidelines on pediatric parenteral nutrition: Energy / K. Joosten, N. Embleton, W. Yan et al. // Clinical nutrition. - Vol 37(6) - P. 2309-2314.

\section{UDC. $616-089.5 .-032: 611.829-0.538$ \\ Zaletskyi B.V1. , Dmytriev D.V ${ }^{1}$., Clazov E.A ${ }^{2}$ \\ ULTRASOUND-GUIDED QUADRATUS LUMBORUM BLOCK IN CHILDREN AFTER URGENT ABDOMINAL SURGERY: TRANS-MUSCULAR VERSUS INTRA-MUSCULAR APPROACH}

National Pirogov Memorial Medical University, Vinnytsya, Ukraine ${ }^{1}$. Odessa regional children hospital, Odessa, Ukraine ${ }^{2}$.

\section{INTRODUCTION}

Quadratus lumborum (QL) block in pediatric patients has four approaches. However, there is difference between the four approaches regarding efficacy, safety and adverse effects. The primary objective of this study is to compare the analgesic effect between trans-muscular and intra-muscular approaches of the QL block in children after abdominal surgery.

\section{METHODS}

24 pediatric patients aged between 4 and 10 years $(5,4 \pm 1,3$ years $)$ were enrolled. The patients were randomly classified into two groups: Group TQL includes patients (14 patients) in whom bilateral QL block was performed using trans-muscular approach, and Group IQL (10 patients), which underwent bilateral QL block using an intra-muscular approach. The primary outcome measure was the number of patients who require rescue analgesia in the first $24 \mathrm{~h}$. The secondary outcome measures were VAS score (verbal analog scale), heart rate, non-invasive blood pressure at 2, 4, 6, 12, and $24 \mathrm{~h}$ postoperatively, and postoperative complications.

\section{RESULTS}

In the first $24 \mathrm{~h}$ after surgery, 8 patients in the IQL group $(57.1 \%)$ required rescue analgesia, whereas only 3 patients in the TQL group (30\%) required rescue analgesia. The VAS score was lower in the TQL group than the IQL group at all time intervals up to $24 \mathrm{~h}$ postoperatively. In the TQL group, 4 patients $(28.6 \%)$ developed quadriceps weakness; whereas, 2 patient $(20 \%)$ in the IQL group developed quadriceps weakness.

\section{CONCLUSION}

TQL is better than IQL in the analgesic efficacy following the urgent pediatric abdominal surgery.

Йовенко И.А., Балака И.В.

\section{СТРАТЕГИЯ УПРАВЛЕНИЯ ИНФУЗИОННОЙ ТЕРАПИЕЙ В АИТ: FLUID STEWARDSHIP}

ООО «Дом Медицины» Odrex, г. Одесса, Украина

Внутривенная инфузия жидкости остается наиболее распространенным методом лечения в АИТ. Существуют риски, связанные с недостаточным или избыточным ее использованием. Гиповолемия коррелирует со снижением перфузии органов, ишемией и ПОН. Гиперволемия и пе- регрузка объемом коррелируют с дисфункцией органов, более длительной потребностью в ИВЛ и повышенной смертностью. Побочными эффектами в/в инфузий являются расстройства ВЭБ и КЩС. Управление волемическим статусом у критических пациентов является динамич- 
ным процессом, требующим соответствующего мониторинга. В настоящее время для стратегии управления инфузионной терапией в АИТ предложен термин «Fluid Stewardship» (управление жидкостью) с соблюдением четырех правил безопасности: правильный пациент, правильный препарат, правильный путь введения и правильная доза.

Перегрузку жидкостью определяют как увеличение объема внеклеточной жидкости с положительным ВБ, который приводит к увеличению массы тела пациента > $10 \%$ от исходного уровня. Многочисленные исследования демонстрируют рост риска летальности до $19-70 \%$ в связи с перегрузкой жидкостью. Она увеличивает длительность необходимости лечения в ОИТ и в стационаре в целом, увеличивает необходимость заместительной почечной терапии.

Правило «правильный пациент». Назначение инфузионной терапии для первичной реанимации и неотложной терапии требует индивидуализированного подхода с многократной переоценкой реакции пациента на инфузию на основе динамических тестов (пассивное поднятие ног, сердечный выброс, пульсовое давление и их вариабельность, УЗИ-локация крупных сосудов). Это позволяет определить потребность пациента в инфузии. Ряд заболеваний требуют особых подходов к инфузионной терапии (рабдомиолиз, диснатриемия, чрезмерная потеря жидкости, ожоги, синдром лизиса опухоли, гипергликемические кризы, контрастиндуцированная нефропатия).

Правило «правильный препарат» требует оценки состава инфузионной среды на осмотическое давление, онкотическое давление и кислотно-основное состояние. ИТ массивной кровопотери подразумевает предпочтение продуктам крови перед другими инфузионными средами.

Правило «правильный путь введения» подразумевает оценку возможности использования энтерального пути во всех случаях, где нет противопоказаний или возможен переход от внутривенной к энтеральной жидкости. Рекомендуют тщательный контроль возможного «скрытого» увеличения поступления жидкостей (например, при питании).

Правило «правильная доза» требует постоянной переоценки реакции пациента на терапию и коррекции объема инфузии с тенденцией к его возможному ограничению.

Следует помнить о необходимости последовательного подхода к основным компонентам ИТ, чему способствует использование мнемонической конструкции FASTHUGS BID (feeding - питание, analgesia - анальгезия, sedation - седация, thromboembolic prophylaxis тромбоэмболическая профилактика, head of bed elevation - положение в кровати с приподнятым головным концом, ulcer prophylaxis - профилактика стрессязв жкт, glycemic control - гликемический контроль, spontaneous breathing trial - стремление к восстановлению спонтанного дыхания, bowel regimen - кишечный пассаж, indwelling catheter removal - удаление инвазивных устройств, de-escalation of antibiotics - де-эскалация антибиотикотерапии) с добавлением в качестве второго «F» управления жидкостью в качестве ежедневного компонента ИT - F ASTHUGS BID.

\section{ЛИТЕРАТУРА:}

1. Critically ill patients need "FAST HUGS BID"(an updated mnemonic). Vincent WR, Hatton KW. // Crit Care Med. 2009;37(7):2326-2327.

2. Fluid Stewardship During Critical Illness: A Call to Action. Hawkins WA, Smith SE, Newsome AS, Carr JR, Bland CM, Branan TN. // J Pharm Pract. 2019;30:897190019853979. doi: 10.1177/ 0897190019853979

УДК $616.75-092-07$

\section{ЙОВЕНКО И.А., ЙОВЕНКО А.И., ГАВРИЧЕНКО Д.Г., БАЛАКА И.В. НЕКРОТИЗИРУЮЩИЙ ФАСЦИИ: ДИАГНОСТИКА И ИНТЕНСИВНАЯ ТЕРАПИЯ \\ ООО «Дом Медицины» Odrex, г. Одесcа, Украина \\ КНП «Кировоградская областная больница», г. Кропивницкий, Украина}

Некротические инфекции мягких тканей (necrotizing soft tissue infections (NSTI) - это тяжелые и очень быстро прогрессирующие инфекции кожи, подкожной клетчатки, фасции и мышц. Летальность заболевания составляет около $25 \%$, а инвалидность, осложнения и потеря пораженной конечности встречается у $15 \%$ пациентов. Выживаемость при этой патологии ниже у пациентов с отсроченным началом соответствующей терапии после инфицирования. Некротический фасциит может развиваться после хирургических вмешательств, небольших травм, царапин, как на фоне хронического поражения кожи, так и у ранее здоровых лиц.

Исторически, заболевание известно с 1871 г. с момента описания Joseph Jones как «госпитальной гангрены». B 1952 г. B.Wilson был установлен ведущий патогномоничный признак - фасциальный некроз, поэтому общепризнанным стало определение - «некротизирующий фасциит».

Состав возбудителей инфекций мягких тканей включает высокопатогенные штаммы стрептококка, стафилококка, или комбинации грам-негативных и анаэробных бактерий.

В качестве предрасполагающих факторов описывают сахарный диабет, иммунодефицитные состояния, травмы мягких тканей, инъекционную наркоманию, длительное применение кортикостероидов, послеоперационные инфекционные осложнения, избыточную массу тела, пожилой возраст, заболевания периферических сосудов.

Заболевание начинается неспецифично: лихорадка, боли в пораженном участке тела и его отек, гиперемия, гипо- или гиперестезия, подкожная крепитация. Может обратить на себя внимание несоответствие между интенсивностью боли и минимальными местными проявлениями. Последующая клиническая симптоматика включает эритему, напряженный отек, изменение окраски кожи до серого с синюшным оттенком, наличие булл с геморрагическим содержимым, изъязвлений и некрозов кожи. На более поздних стадиях инфекционный процесс распространяется локально по фасциям, вызывая тромбозы и нарушая васкуляризацию кожи. Высокий риск развития бактериемии и сепсиса.

Для ранней диагностики фасциального некроза можно использовать УЗИ и МРТ мягких тканей, биопсию тканей. При наличии фасциального некроза и поражения мышц определяют повышение уровня активности креатинфосфокиназы.

Стандартная практика лечения заболевания включает раннюю радикальную хирургическую обработку и резек- 
цию некротических тканей на фоне полноценной антибактериальной терапии, раннюю эмпирическую антибиотикотерапию с последующей коррекцией по данным бакпосевов, поддерживающую интенсивную терапию и вспомогательную терапию (гипербарическая оксигенация, внутривенный иммуноглобулин и другие способы иммунокоррекции).

В рамках Конгресса планируется презентация собственных клинических наблюдений ИТ некротизирующего фасциита.

\section{СПИСОК ЛИТЕРАТУРЫ}

1. Multidrug resistant Proteus mirabilis and Escherichia coli causing fulminant necrotising fasciitis: a case report. Yeika EV, Foryoung
$J B$, Efie DT, Nkwetateba EA, Tolefac PN, Ngowe MN. // BMC Res Notes. 2018 - 11(1):322. doi: 10.1186/s13104-018-3413-7.

2. Multidrug-resistant Aeromonas hydrophila causing fatal bilateral necrotizing fasciitis in an immunocompromised patient: a case report. Ugarte-Torres A, Perry S, Franko A, Church DL. // J Med Case Rep. 2018 - 12(1):326. doi: 10.1186/s13256-018-1854-1.

3. Interventions for necrotizing soft tissue infections in adults. Hua C. Bosc R, Sbidian E, De Prost N, Hughes C, Jabre P, Chosidow O, Le Cleach L. // Cochrane Database Syst Rev. 2018 - 5:CD011680. doi: 10.1002/14651858.CD011680.pub2.

4. К ранней диагностике некротизирующего фасчиита. Шагиняи Г.Г., Ефремов А.В., Чеканов М.Н., Штофин С.Г. // Вестник эксперимент и клин хирургии. 2012 - том V, №1, С. 120-125.

5. Некротизирующий фасиичт - ургентное состояние в медицине. Николов В.В. // Острые и неотлогсые состояния в практике врача. - 2015. - № 2. - C. 27-31

УДК $616.75-092-07$

Карпенко Н.П., Ісаєва А.Ф., Головня О.М., Гунько С.Г.

\section{РЕЗИСТЕНТНІСТЬ ДО АНТИБІОТИКІВ ШТАМІВ KLEBSIELLA PNEUMONIA, ВИДІЛЕНИХ ВІД ДІТЕЙ У ВІДДІЛЕННЯХ РЕАНІМАЦІЇ TA IHTEНСИВНОÏ ТЕРАПIÏ}

НДСЛ «Охматдит» МОЗ України

META

Визначення антибіотикорезистентності штамів Klebsiella pneumonia, виділених від дітей у ВІT, для вибору другої лінії антибіотикотерапії.

\section{МАТЕРІАЛИ ТА МЕТОДИ}

Обєктом дослідження були штами Klebsiella pneumonia, виділені з крові, ліквору, виділень нижніх дихальних шляхів, гною і виділень області хірургічного втручання, сечі, тощо.

В період за 2016-2018 pр. ізольовано 141 штам К. pneumonia від дітей, що знаходились на лікуванні у BIT.

Видова ідентифікація мікроорганізмів та визначення чутливості проводилась на аналізаторі Vitek2Compact (bioMerieux), визначення чутливості до колістину методом серійних розведень в бульйоні (система Liofilchem) Iнтерпретація даних чутливості здійснювалась у відповідності до методології EUCAST. Підтвердження продукції карбапенемаз визначалась CIM тестом (CLSI), визначення фенотипу карбапенемаз методом виявлення синергії карбапенемів подвійними дисками $з$ фенілбороновою кислотою і ЕДТА та чутливості до темоциліну (EUCAST). Синергічна дія антибіотиків визначалась методом перехресного тестування 3 використанням МІК стрипів (Liofilchem).

\section{РЕЗУЛЬТАТИ}

Серед виділених 141 штаму К.pneumoniae 14,2\% були продуцентами БЛРС, стійкість до меропенему - 48,7\%, іміпенему - 49,6\%, ертапенему - 50,1 \% - штамів. Резистентність до карбапенемів була зумовлена карбапенемазою КРС у 72,2\%, метало-бета лактамазою у 16,7\%, карбапенемазою типу ОХА-48 у 2,7\%.

У штамів K. pneumonia, продуцентів карбапенемаз, виявлена множинна стійкість до інших груп антибіотиків: до аміноглікозидів (гентаміцину, амікоцину, тобраміцину) у $27,7 \%, 28,9 \%$ та 30,5\% штамів відповідно, до ципрофлоксацину - $82,3 \%$, до тігецикліну у $14,2 \%$, та до колістину $0,7 \%$ (1 штам). Триметоприм/сульфаметоксазол $33.3 \%$.
Для панрезистентних штамів за результами визначення синергічної дії для пар антибіотиків: карбапенем 3 карбапенемом, карбапенем з фторхінолоном, карбапенем 3 аміцноглікозидом, карбапенем з фосфоміцином, карбапенем 3 тігецикліном, карбапенем 3 колістином та колістин 3 фосфоміцином, колістин 3 тігецикліном розраховувався коефіцієнт - фракційна інгібуюча концентрація (FIC), що дозволяє вибирати антибіотики для комбінованої терапії.

КЛІНІЧНИЙ ВИПАДОК

Дитина 9 міс.,планове оперативне втручання. Ранній післяопераційний період без особливостей, на 9-ту добу різке погіршення стану переведена у ВІТ, ДНІІІ, ШВЛ, CCH III, діурез - олігурія (0.5 мл/кг/год). Лабораторно гіпоглікемія, лейкоцитоз до 28, тромбоцитопенія до 25 , високі трансамінази (10 норм), ДВ3 синдром. По КОС лактат ацидоз (лактат >20). ФВ=46 (на інфузії добутаміну), NTpro-BNP-26938.00 нг/мл, СРБ 146 нг/мл, РСТ 28 нг/мл.

Діагноз: Сепсис. ІТШ. РДС. ДН ІІІ, ССН ІІІ. Ентеральна недостатність. Розпочато антибактеріальну терапію: меронем, колістин. Відносна стабілізація (гемодинамічно стабільний, ШВЛ). Розпочате ентеральне харчування різке погіршення стану за рахунок транслокації кишкової флори (Refeeding синдром виключено). Посилена антибактеріальна терапія ертапенемом. Клінічне покращення, але залишаються тромбоцитопенія, трансфузійнозалежний, ентеральна недостатність. Результати бак посівів крові панрезистентна K.pneumoniae чутлива тільки до TMP/ CMК, тип карбапенемази КРС, ШКТ К.pneumoniae $10^{7}$. В терапію додано ТМР/CMK. Досягнене клінічне та лабораторне одужання, дитина на 3-тю добу переведена із ВIT, редукція а/б терапії.

\section{ВИСновкИ}

Частота виділення карбапенемрезистентних штамів K.pneumoniae BPIT - біля 50\%, домінуючий фенотип карбапенемаза КРС, комбінована антибіотикотерапія $є$ шляхом успішної терапії інфекцій, спричинених карбапенемрезистентними штамами. 


\author{
Клигуненко О.М., Площенко Ю.О., Новіков С.П., Кирилова Л.О., \\ Василишин О.В., Карась Р.К., Бородай Л.В., Фролов К.Б.
}

\title{
ДОСВІД ЗАСТОСУВАННЯ КРОВОЗБЕРІГАЮЧИХ ТЕХНОЛОГІЙ ПРИ ХІРУРГІЧНОМУ ЛІКУВАННІ ХВОРИХ НА КОЛОРЕКТАЛЬНИЙ РАК. КЛІНИКО-МОРФОЛОГІЧНІ ПАРАЛЕЛІ
}

\section{м. Дніпро}

\section{АКТУАЛЬНІСТЬ}

Проблема гемотрансфузії постала вкрай актуально, наразі простежується невпинний науковий прогрес в розумінні молекулярних механізмів газообміну між гемоглобіном еритроцитів та периферичними тканинами організму, транспорту кисню еритроцитами, компенсаторних реакцій при розвитку гіпоксії. Розроблені принципово нові підходи відновлення крововтрати при хірургічному втручанні дозволяють уникнути застосування донорської крові або значно зменшити гемо трансфузію, дотримуючись рестриктивного типу відновлення крововтрати [1]. Рандомізовані контрольовані дослідження, які оцінювали «пороги» гемоглобіну для гемотрансфузії встановили, що обмежуючі стратегії переливання є безпечнішими, ніж ліберальні [2-5].

На сьогодні важливим залишається питання можливості обмеження аллогенної трансфузії компонентів крові. В нашій практиці ми вже мали досвід лікування пацієнтів із релігійної групи Свідків Ієгови при проведені великих оперативних втручань, що супроводжувались значною крововтратою [5]. В таких випадках ми використовували препарати стимулятори еритропоезу із комбінацією з препаратами заліза (III) оксиду, і така тактика показала достатню клінічну ефективність. На основі цього досвіду ми прийшли до висновку, що дана методика може бути використана у пацієнтів онкопроктологічного профілю, яким планується «велике» оперативне втручання, і може замінити стандартний трансфузійний менеджмент із використанням препаратів крові [6].

\section{МЕТА ДОСЛІДЖЕННЯ}

Аналіз динаміки еритропоезу і змін тканинної і клітинної ультраструктури в інтраопераційних біоптатах товстої кишки після стимуляції еритропоезу в передопераційнії підготовці при хірургічному лікуванні хворих на колоректальний рак.

\section{МАТЕРІАЛИ ТА МЕТОДИ}

У дослідженні брали участь 50 пацієнтів, яким планувалося радикальне оперативне втручання 3 приводу колоректального раку з передбачуваною крововтратою від 0,6 до 1,0 л; вік пацієнта 60-75 років. Передопераційно у паціентів 1-ї групи $(\mathrm{n}=25)$ за 5 діб до планованого оперативного втручання був підшкірно введений препарат епоетину-альфа (еритропоетин) в дозі $10000 \mathrm{MO}$, з метою стимуляції еритропоезу перед крововтратою. Вихідний рівень показників гемоглобіну у пацієнтів даної групи

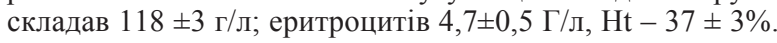
Як додатковий компонент посилення кровотворення використовувався препарат Заліза (III) оксид в дозі 1,5 мг/кг маси тіла хворого у вигляді внутрішньовенної інфузії розведеного розчину у 200 мл $\mathrm{NaCl} 0,9 \%$. Препарат вводився тричі: за 5-ть, 3-и доби перед оперативним втручанням, та інтраопераційно. В подальшому трансфузія еритроцитів в даній групі не планувалась. Періопераційно для пацієнтів обох груп була обрана тактика рестриктивної інфузійної терапії [7]. В обох групах інтраопераційно проведена стернальна пункція, відібраний пунктат підлягав ультраструктурному дослідженню на кількісний склад нормобластів. Для електронномікроскопічного дослідження, під час радикального оперативного втручання 3 ділянок макроскопічно незміненної товстої кишки, прилеглих до ураженої колоректальной зони, витягувались біоптати розміром 1 мм $^{3}$. Дослідження проводилися за допомогою трансмісійного електронного мікроскопа ПЕМ-100-01 (“SELMI”, Україна) при первинних збільшеннях від 2000 до 40000. В цілому, електронномікроскопічне дослідження проводили за стандартною схемою.

\section{РЕЗУЛЬТАТИ}

Стимуляція еритропоезу за допомогою епоетину призводить до підвищення функціональної активності центральних макрофагів еритропоетичних острівців червоного кісткового мозку і посилення їх міжклітинної асоціації.

Стимуляція еритропоезу епоетином в передопераційному періоді обумовлює стримування ендотеліальної дисфункції за рахунок обмеження дистрофічних і деструктивних змін органел ендотеліальних клітин, стабілізації їх мембран, запобігання спазму артеріол, явищ стазу і сладжа еритроцитів. Явища інфільтрації, периваскулярного інтерстиціального набряку в складі оболонок кишкової стінки виражені меншою мірою.

\section{ВИСНОВКИ}

«Безкровна» стратегія періопераційної інфузійнотрансфузійної терапії у пацієнтів при радикальних операція 3 приводу колоректального раку є досить ефективним методом в порівнянні з традиційною тактикою з використанням гемотрансфузій, що підтверджено ультрамікроструктурно.

\section{СПИСОК ЛІТЕРАТУРИ}

1. The European guideline on management of major bleeding and coagulopathy following trauma: fourth edition 2016.

2. Hebert PC, Wells G, Blajchman MA, Marshall J, Martin C, Pagliarello $G$, et al. A multicenter, randomized, controlled clinical trial of transfusion requirements in critical care. Transfusion Requirements in Critical Care Investigators, Canadian Critical Care Trials Group. N Engl J Med. 1999;340(6):409-17.

3. Hajjar LA, Vincent JL, Galas FR, Nakamura RE, Silva CM, Santos $M H$, et al. Transfusion requirements after cardiac surgery: the TRACS randomized controlled trial. JAMA. 2010;304(14):1559-67.

4. Villanueva C, Colomo A, Bosch A, Concepcion M, Hernandez-Gea V. Aracil $C$, et al. Transfusion strategies for acute upper gastrointestinal bleeding. N Engl J Med. 2013;368(1):11-21.

5. Клигуненко Е.Н., Плоченко Ю.А., Новиков С.П., Карась Р.К. Гавриш К.В., Кириллова Л.А., Бородина И.А., Лапкин И.В., Бородай Л.В. "Клинический случай успешного периоперачионного ведения пачи"Клиническии случай успешного периоперационного ведения пациента религиозной группы "Свидетели Иеговы" с интраоперацион-
ной кровопотерей II степени».// ЖУРНАЛ "МЕДИЦИНА НЕОной кровопотерей ІІ степени».). ЖЛОРА

6. Клигуненко О.М.(1), Площенко Ю.О., Новіков С.П., Фролов К.Б.(2), Кирилова Л.О.(2), Гавриш К.В., Карась Р.К. "Періоперачійне впровадження кровозберігаючих технологій в інтенсивній те рапії хворих онкопроктологічного профілю»// ЖУРНАЛ «МЕДИ

7. Глумчер Ф.С., Клигуненко О.М. «Инфузионно-трансфузионная терапія».// Киев, издательский дом «Заславский», 2018 г. 
Коваленко О.М., Коваленко А.О., Гриша А.С.

\section{ПОМИЛКИ ПРИ ТРАНСПОРТУВАННІ ВАЖКООБПЕЧЕНИХ ДО СПЕЦІАЛІЗОВАНОГО СТАЦІОНАРУ}

Національний медичний університет імені О.О. Богомольця, м. Київ

Київська міська клінічна лікарня №2, опіковий центр.

\section{ВСТУП}

Летальність в стадії опікового шоку (ОШ) в Україні становить $27 \%$ від усіх померлих внаслідок опіків у стаціонарі. Причиною летальності є рання поліорганна недостатність. Такий стан потребує своєчасного відновлення об'єму циркулюючої крові (ОЦК) і корекції розладів гомеостазу уже на етапах транспортування до спеціалізованого стаціонару.

\section{META РОБОТИ}

Вивчити вплив ранньої інфузійної терапії (IT) на перебіг і наслідки опікової хвороби при транспортуванні обпечених до спеціалізованого стаціонару.

\section{МАТЕРІАЛИ I МЕТОДИ}

Під спостереженням знаходилось 60 хворих віком від 18 до 67 років із тяжкими опіками загальною площею ураження 30-70\% поверхні тіла, госпіталізованих до відділення опікової реанімації центру термічних уражень і пластичної хірургії Київської МКЛ №2 через 1-72 год. після отримання травми протягом 2014-2018 pр. Основну групу склали 35 хворих, госпіталізованих протягом 1-3 год. після травми, яким проводилася базисна IT по протоколу МO3 із застосуванням протягом 3 днів інфузії реосорбілакту. Групу порівняння склали 25 хворих, які були переведені із інших лікувальних закладів 3 іншим обсягом інфузійної терапії на попередньому етапі та під час транспортування. Критеріями оцінки ефективності IT були строки виходу із шоку, термін початку оперативних втручань, кількість органних ускладнень, летальність та строки лікування.

\section{РЕЗУЛЬТАТИ ТА ЇХ ОБГОВОРЕННЯ}

В основу IT ОШ хворих було покладено клінічні протоколи надання медичної допомоги хворим з опіками та їх наслідками, введені в дію наказом МО3 України №691 від 07.11.07. Достатність IT оцінювалась за погодинним діурезом, САТ, ЦВТ, загальними аналізами крові, газів крові, які тестувалися кожні 8 год. При відсутності ефекту від IT протягом перших 6-8 год. обсяг і швидкість інфузії збільшувалися до відновлення гемодинаміки та діурезу. При збільшенні діурезу більше 1 мл/кг/год. наступної години зменшували обсяг інфузії. Колоїдні препарати вводилися тяжким і вкрай тяжким хворим через 12 год. після травми. При аналізі результатів лікування виявлено, що у хворих основної групи через добу після госпіталізації ЦВТ був вищим, ніж у хворих групи порівняння $(7,2 \pm 0,6$ i $2,6 \pm 0,2$ см.вод.ст.), через 8 год. після травми хворим основної групи перелито рідини $2,3 \pm 0,5$ мл/кг $/ \%$ опіку, а хворим групи порівняння- $0,9 \pm 0,4$ мл/кг/\% опіку. Отрима- но сечі: 0,6 0,2 мл/кг/год. у хворих основної групи i $0,3 \pm 0,1$ мл/кг/год. у хворих групи порівняння. Обсяг інфузії для корекції гемодинамічних порушень протягом першої доби у хворих основної групи склав 3,5 мл/кг/\% добу, а у хворих групи порівняння - 2,2 мл/кг/\%. Протягом лікування пневмонія розвинулася у 8 хворих $(23,8 \%)$ основної групи і у 9 постраждалих (36\%) групи порівняння, токсичний міокардит - у 6 хворих $(17,1 \%)$ основної групи і у 6 хворих (24\%) групи порівняння, шлунковокишкова кровотеча - у 5,7\% хворих основної групи і у $12 \%$ хворих групи порівняння. У хворих, переведених 3 етапів евакуації, спостерігалося погіршення мікроциркуляції в ранах, їх поглиблення, поява вторинних некрозів. Летальність становила 2,9\% у хворих основної групи і $8 \%$ в групі порівняння. Стабілізація гемодинаміки, вихід із шоку у хворих основної групи спостерігались на $3,5 \pm 0,5$ доби, а у хворих з етапів евакуації - на 7,5 1 ,2 доби, строки початку оперативних втручань - відповідно на $3,5 \pm 0,4$ доби і $8,5 \pm 1,3$ доби.

\section{вИСновки}

Інфузійна терапія по протоколу МО3 має починатися на догоспітальному етапі і тривати в умовах стаціонару. Набутий досвід лікування хворих з термічною травмою свідчить, що ускладнення у хворих з термічною травмою знаходиться в прямій залежності від строків початку і обсягів IT. Несвоєчасно розпочата IT при опіковому шоці збільшує летальність в 2,8 рази.

\section{СПИСОК ЛІТЕРАТУРИ}

1. Frederick $W$ Endorf, David J Dries. Burn Resuscitation//Scand J Trauma Resusc Emerg Med. 2011; 19: 69. Published online 2011 Nov 11. doi: 10.1186/1757-7241-19-69

2. Коваленко О.М. Питання інфузійної терапї опікового шоку О. М. Коваленко // Хірургія України. - №2. - 2014. - C. 11-17. http: /combustiology.at.ualfiles/KhU_2014_2_4.pdf

3. Козинечь Г.П. Діяльність комбустіологічної служби украӥни за 2014-2017 роки//Пластична, реконструктивна і естетична хірургія.-2018. - № 3-4.C. 6-10.

4. Hayek S. Burn resuscitation: is it straightforward or a challenge? S. Hayek, A. Ibrahim, Abu G.Sittah, B. Atiyeh // Ann Burns Fire S. Hayek, A. Tbrahim, Abu G.Sittah, B. Aliye

5. Alekseev A.A. Tyurnikov Yu.I. Analysis of activities of burns centersin Alekseev A.A., Tyurnikov Yu.I. Analysis of activities of burns centersin
the Russian Federation in 2016. (Epub.) Kombustiologiya, 2017, no the Russian Federation in 2016. (Epub.) Kombustiologiya, 2017, no.
$59-60$ (In Russ.) http://combustiolog.ru/journal/sbonik-nauchny$59-60$ (In Russ.) http://combustiolog.ru/journal/sbonik-nauchny-
hrabot-chast-pervayal

6. Pediatric burn resuscitation: past, present, and future. Kathleen $S$ Romanowski, Tina L. Palmieri //Burns Trauma. 2017; 5: 26 doi: 10.1186/s41038-017-0091-y

7. A primer on burn resuscitation Ferdinand $K$ Bacomo, Kevin $K$ Chung //J Emerg Trauma Shock. 2011 Jan-Mar; 4(1): 109-113 doi: 10.4103/0974-2700.76845

8. Pham TN, Cancio LC, Gibran NS; American Burn Association. American Burn Association practice guidelines burn shock resuscitation. J Burn Care Res. 2008 Jan-Feb;29(1):257-66. doi: 10.1097/BCR.0b013e31815f3876. 


\section{РЕКОМЕНДАЦІЇ ПО АНТИБАКТЕРІАЛЬНІЙ ТЕРАПІЇ ІНФЕКЦІЙНИХ УСКЛАДНЕНЬ СУЧАСНИХ БОЙОВИХ ПОРАНЕНЬ, ЯК ОСНОВА АНТИБАКТЕРІАЛЬНОГО СТЮАРДШИП}

\section{АКТУАЛЬНІСТЬ ПРОБЛЕМИ}

Проблема поширення мікроорганізмів, що характеризуються множинною стійкістю до антибіотиків визнана ВООЗ як одна з трьох найбільших загроз людству. Однією із запропонованих стратегічних ініціатив є поглиблення знань про стійкість до антибіотиків серед мікроорганізмів шляхом мікробіологічного нагляду [1]. Створенні на основі цих об'єктивних даних протоколи та рекомендації $\epsilon$ основою для формування грамотного стереотипу у лікарів та створення керівництва по контролю за антибактеріальною терапією у шпиталях - антибактеріального стюардшип [2].

\section{META РОБОТИ}

Робота була спрямована на створення керівництва 3 антибактеріальної терапії інфекційних ускладнень бойових поранень.

\section{МАТЕРІАЛИ ТА МЕТОДИ}

Мікробіологічний моніторинг (бактеріологічне дослідження поранень) охопив всі існуючі рівні хірургічної допомоги пораненим під час антитерористичної операції у 2014 - 2016 pp.

Встановлено, що в етіологічній структурі інфекційно запальних ускладнень бойових поранень переважають грамнегативні палички (85,7 \% позитивних висівів). У 78,6 \% випадків виділяються неферментуючі палички, чверть штамів 3 яких належать до роду - Pseudomonas, решта Acinetobacter. Частота виділення метицилінрезистентних штамів стафілококів встановлена понад 20\%. Лише антибіотики коломіцин та тігециклін активні до $75 \%$ штамів причинних мікроорганізмів. Частка карбапенемрезистентних штамів серед ентеробактерій, псевдомонад та акінетобактерій широко коливається від $25 \%$ до $100 \%$. Фторхінолони та актами втратили свою дієвість. Ефективні у відношенні коків - ванкоміцин, фосфоміцин, тігециклін та лінезолід. До гатіфлоксацину та моксіфлоксацину чутливі $70 \%-100 \%$ виділених культур.

\section{висновки}

На основі одержаних даних про чутливість до антибіотиків вперше розроблені організаційно-методичні рекомендації, щодо профілактики і лікування інфекційних ускладнень у поранених [3]. Даній документ є підгрунтям для побудови системи контролю якості за антибактеріальною терапією (стюардшип) та фундаментом для заходів управління антибактеріальною терапією в госпіталях.

\section{СПИСОК ЛІТЕРАТУРИ}

1. Pollack L. A., Srinivasan A. Core elements of hospital antibiotic stewardship programs from the Centers for Disease Control and stewardship programs from the Centers for Disease Control and
Prevention ClinInfect Dis. 2014. Oct 15 . Vol. 59 N3. P 97-100 doi: 10.1093/cid/ciu542. Dis. 2014. Oct, 15. Vol. 59 N3. P. 97-100. doi: 10.1093/cid/cius42.

Siegel J. D., Rhinehart E., Jackson M., Chiarello L., Healthcare Infection Control Practices Advisory Committee. Management of Multidrug-Resistant Organisms In Healthcare Settings. 2006. URL: https://www.cdc.gov/hicpac/pdf/MDRO/MDROGuideline2006.pdf.

3. Організачія надання медичної допомоги військовослужбовиям із бойовими пораненнями кінцівок та м'яких тканин: роль етіотропної терапї організачійно-методичні вказівки/ І. П. Хо менко, та ін.,. Київ. 2018. 31 с

\section{Корогод C.H.}

УДК 616.832.9-002-036.11-08

\section{ВОЗМОЖНОСТИ ИНТЕНСИВНОЙ ТЕРАПИИ БАКТЕРИАЛЬНЫХ МЕНИНГОЭНЦЕФАЛИТОВ}

Государственное заведение "Запорожская медицинская академия последипломного образования МЗ Украины"

\section{ВВЕДЕНИЕ}

При тяжелой, осложненной форме менингоэнцефалита летальность может достигать 40-60%.(В.И. Матяш и соавт., 2012)

\section{ЦЕЛЬ РАБОТЫ}

Проанализировать интенсивную терапию у больных с бактериальными менингоэнцефалитами, пролеченных в отделении интенсивной терапии Запорожской областной клинической инфекционной больницы в 2016 - 2018 году.

\section{МАТЕРИАЛЫ И МЕТОДЫ}

Пролечено 27 пациентов, мужчин было 18 в возрасте $54,3 \pm 13,3$ (30-79) года, женщин - в возрасте 51,616,1 (26$75)$ года. У 7 пациентов этиология заболевания не выяснена, у 2 - St. pyogenus, по одному - Enterococcus spp, H. Influenzae, Staph. aureus (MRSA), y 15 - St. pneumoniae. Диагноз выставлен на основании эпидемиологических данных, типичной клинической картины, клинико-лабораторных и бактериологических исследованиях крови и ликвора. Для проведения интенсивной терапии использовали:

- антибактериальную терапию внутривенно в максимальных суточных дозах: антибиотиками - цефалоспорины III-IV поколения в комбинации с аминогликозидами или меропенем с ванкомицином;
- дексаметазон - 0,15 мг/кг каждые 6 часов в течение 5 суток;

- ИВЛ аппаратом Hamilton C - 2 в режимах $\mathrm{PCV}(+)$, BiPAP, ASV;

- инфузионную терапию кристаллоидами и для устранения гиповолемии и достижения целевых цифр среднего артериального давления (Ср.АД $=80-90$ мм.рт.ст).

- суточный гемогидробаланс, после устранения изотонической дегидратации и достижения гемодилюции (Ht - 0,32-0,35) поддерживался на уровне ноля. Суточную потребность жидкости вводили энтерально в объеме 20-25 мл/кг;

- пентоксифиллин - 5 мг/кг сутки;

- гепарин нефракционированный 5 тыс Ед каждые 8 часов, или клексан - 0,4 мл/сутки;

- антиоксиданты: токоферол ацетат 300 мг/сутки, аскорбиновая кислота 10 мг/кг сутки;

- седация: тиопенталом или оксибутиратом натрия с лидокаином или пропофолом (уровень седации Ramsey II-III);

- энтеральное зондовое питание - 10 - 15 ккал/кг в сутки; 
- нейропротекцию: цитиколином 2 грамма в сутки и нейромедином.

РЕЗУЛЬТАТЫ ИССЛЕДОВАНИЙ И ОБСУЖДЕНИЕ

У больных при поступлении тяжесть состояния была обусловлена выраженным эндотоксикозом вплоть до септического шока у 4 (16\%) пациентов; гиповолемией вследствие изотонической дегидратации; тромбгеморрагическим синдромом (геморрагическая сыпь и петехии на коже); полиорганной недостаточностью (печеночно-почечной, дыхательной) и энцефалопатией с нарушением уровня сознания по шкале ком Глазго до 82,2 баллов у 15 (60\%) пациентов. У 5 (20\%) пациентов была диагностирована пневмония. Проведение искусственной вентиляции легких (ИВЛ) потребовалось у $16(59,3 \%)$ пациентов в течение 4-9 суток. Средний койко-день составил 11,7. Умерло 5 $(18,5 \%)$ пациентов.

\section{выводы}

1. Тяжелое течение бактериальных менингоэнцефалитов характеризуется церебральной и полиорганной недостаточностью.

2. Использование интенсивной терапии позволяет снизить летальностью до $18,5 \%$.

\section{Корогод С.Н., ${ }^{1}$ Поталов С.И. ${ }^{2}$ \\ УДК $616.24-002: 616.915]-036.882-082-053.8$ \\ ИНТЕНСИВНАЯ ТЕРАПИЯ КОРЕВОЙ ПНЕВМОНИИ У ВЗРОСЛЫХ \\ Государственное учреждение "Запорожская медицинская академия последипломного образования МОЗ Украины" \\ ${ }^{1}$ Кафредра анестезиологии та интенсивной терапии, ${ }^{2}$ Кафредра неотложной медицини}

\section{ВВЕДЕНИЕ}

По оперативным данным Центра общественного здоровья МОЗ Украины в 2018 - 2019 годах отмечается вспышка кори - заболело 10588 взрослых, умерло 30 пациентов.

\section{ЦЕЛЬ РАБОТЫ}

Проанализировать проведенную интенсивную терапию у больных корью, которые лечились в отделении интенсивной терапии Запорожской областной клинической инфекционной больницы в 2018 - 2019 году.

\section{МАТЕРИАЛЫ И МЕТОДЫ}

Пролечено 14 пациентов, мужчин было 4 в возрасте $44,9 \pm 13,1$ (37-55) года, женщин - 10 в возрасте $34,716,1$ $(25-52)$ года, из них 2 беременных в сроках 27 и 30 недель. Диагноз выставлен на основании эпидемиологических данных, типичной клинической картины, клинико-лабораторных и бактериологических исследованиях. Для проведения интенсивной терапии использовали:

- антибактериальную терапию внутривенно в среднетерапевтических суточных дозах: цефалоспорины III поколения в комбинации с левофлоксацином;

- иммуноглобулин внутривенный 0,4 гр/кг однократно;

- оксигенотерапию, ИВЛ аппаратом Hamilton C - 2 в режиме $\mathrm{PCV}(+)$ с ПДКВ. При проведении ИВЛ осуществлялся графический мониторинг по петлям давление/объем или поток/объем в зависимости от паттерна ИВЛ;

- инфузионную терапию рестрективную кристаллоидами для устранения гиповолемии и достижения целевых цифр среднего артериального давления (Ср.АД $=70$ мм. рт.ст).

- суточный гемогидробаланс, после устранения изотонической дегидратации и достижения гемодилюции (Ht - 0,35) поддерживался на уровне ноля. Суточ- ную потребность жидкости вводили энтерально в объеме 20-25 мл/кг;

- TIVOR-L® - 100 мл в сутки в виде инфузии за 4 часа;

- клексан - 0,4 мл/сутки;

- антиоксиданты: токоферол ацетат 300 мг/сутки, аскорбиновая кислота 10 мг/кг сутки;

- седация: пропофолом (уровень седации Ramsey II-III);

- энтеральное зондовое питание - $10-15$ ккал/кг в сутки;

РЕЗУЛЬТАТЫ ИССЛЕДОВАНИЙ И ОБСУЖДЕНИЕ

У больных при поступлении тяжесть состояния была обусловлена выраженным воспалением (лекоцитоз 14,32,4 109 л, палочкоядерных нейтрофилов $18,24,4)$; гипердинамией сердечнососудистой системы (тахикардией 113,512,3 в мин., артериальной гипертензией 158,7/85,612,7/8,7 мм рт. ст.); тромбгеморрагическим синдромом (геморрагическая сыпь и петехии на коже); полиорганной дисфункцией: почечной (креатинин плазмы 162,324,2 мкмоль/л), дыхательной (тахипноэ 30,44,6 в мин., $\mathrm{SpO} 2$ 90,32,3\% и энцефалопатией с нарушением уровня сознания по шкале ком Глазго до 12,52,2 баллов у 6 (50\%) пациентов. Рентгенологическая картина - двухсторонние очаговые изменения у $10(83,3 \%)$ пациентов. Проведение искусственной вентиляции легких (ИВЛ) потребовалось у 1 беременной пациентки в течение 3 суток. Умерших пациентов не было.

\section{ВЫВоды}

1. Тяжелое течение кори характеризуется воспалением, токсико-гипоксической энцефалопатией и полиорганной дисфукцией (дыхательной и почечной), вследствие вирусной пневмонии.

2. Использование в интенсивной терапии ИВЛ, эндотелиопротекторов, внутривенного иммуноглобулина позволило избежать летальности. 


\section{Котурбаш Р. Ю, Тхоревський О. В. ПОПЕРЕДЖЕННЯ КОГНІТИВНОЇ ДИСФУНКЦІЇ, ОБУМОВЛЕНОЇ ВПЛИВОМ ЗАГАЛЬНОЇ AHECTE3IÏ}

Українська військово-медична академія. м. Київ. Укр аїна

\section{АКТУАЛЬНІСТЬ}

Особливою медико-соціальною проблемою серед ускладнень загальної анестезії є післяопераційна когнітивна дисфункція (ПОКД), яка проявляється зниженням інтелектуальних функцій, зокрема пам’яті, уваги, процесів мислення. Це ускладнює перебіг раннього післяопераційного періоду, а в більш віддаленому терміні погіршує якість життя хворих з урахуванням їх професійної, соціальної та побутової дезадаптації.

\section{META}

Зменшення післяопераційних когнітивних розладів шляхом вибору оптимального анестезіологічного забезпечення.

\section{ЗАВДАННЯ}

1. Дослідити увагу, пам'ять та рівень інтелекту в групах хворих до та після проведення загальної анестезії.

2. Виявити найбільш оптимальне анестезіологічне забезпечення.

3. Дослідити ефективність застосування ноотропів інтраопераційно з метою профілактики когнітивних порушень.

На даний час в експериментальних дослідженнях і численних клінічних спостереженнях доведено, що на когнітивні і психомоторні функції несприятливо впливають практично всі анестетики і наркотичні аналгетики, що використовуються в практиці лікаря-анестезіолога.

ПОКД є багатофакторним ускладненням, обумовленим як шкідливою дією окремих анестетиків, так і недостатнім рівнем антиноцицептивного захисту мозкових структур під час операції і в ранньому післяопераційному періоді, а також ушкоджуючий впливом порушень газообміну, гемодинаміки, гомеостазу в інтра- і ранньому післяопераційному періоді.
Вищенаведені дані підкреслюють необхідність посилення уваги лікарів-анестезіологів до цієї важливої проблеми.

\section{MATEPIA Л}

На базі НВМКЦ «ГВКГ» буде проспективно обстежено 40 хворих, прооперованих на базі клініки хірургії.

Хворі будуть розділені на дві групи, в залежності від анестезіологічного забезпечення

1 група - комбінована інгаляційна анестезія з севофлюраном;

2 група - тотальна внутрішньовенна анестезія на основі пропофолу і фентанілу

У подальшому групи будуть розділені на дві підгрупи в залежності від використання ноотропних засобів. Хворі будуть рандомізовані за віком, статтю та видом оперативного втручання.

Згідно літературних даних на даний момент можна зробити наступний висновок.

\section{вИсновок}

Ранній початок проведення фармакологічної профілактики і корекції дозволяє не тільки попередити розвиток стійкої ПОКД, але і в ряді випадків підвищити рівень психофізіологічних функцій у віддаленому післяопераційному періоді, що покращує якість життя хворих.

\section{ЛІТЕРАТУРА}

1. Новицкая-Усенко Л.В. Послеоперационная когнитивная дисфункция в практике врача-анестезиолога // Медииина неотложных состояний журнал. - 2017. -№4. - С. 9-15.

2. Усенко Л.В., Криштафор А.А. Полынчук И.С., Тютюнник А.Г., Усенко $A$ А. Петрашенок Е В. Послеоперачиониые когнитивные расстройства каи ослолснение обией аиестезии. Зиачение ранией стройства как ослолснение обией анестезии. Значение ранией фармакологической нейропротекции // Медицина неотложны состояний журнал. - 2015. -№2. - С. 24-31.

Крутько Є.М, Середенко В.Г.

\section{СПОСОБИ КОРРЕКЦІЇ ХІРУРГІЧНОЇ СТРЕС-ВІДПОВІДІ ПРИ ОПЕРАТИВНИХ ВТРУЧАННЯХ У ОНКОХВОРИХ}

ДУ «Інститут медичної радіології ім. С.П. Григор'єва НАМН України », м. Харків.

\section{АКТУАЛЬНІСТЬ}

Хірургічна стрес-відповідь є найбільш важливим індуктором дисфункції різних органів і систем. Це визначає особливу вимогу до адекватності анестезіі. Метою нашої роботи була оцінка епідуральної анестезії та аналгезії при операціях на органах черевної порожнини у хворих онкологічного профілю.

\section{МАТЕРІАЛИ ТА МЕТОДИ}

Для оцінки ефективності епідуральної анестезії (ЕА) та аналгезії були сформовані 2 групи пацієнтів, при операціях на органах черевної порожнини у хворих онкологічного профілю. Основну групу склали 75 пацієнтів, яким була застосована поєднана анестезія: епідуральна анестезія в складі багатокомпонентної загальної анестезії (БЗА + ЕА) 3 використанням фентанілу. Вік пацієнтів становив $63 \pm 4$ років, ризик анестезії оцінювали як III-IV ст. за класифікацією ASA. Контрольна група - 31 пацієнт, оперований в умовах БЗА. Оцінка показників центральної і переферичної гемодинаміки проводилась методом реог- рафії, проводилась оцінка ряду предикторів операційного стресу, окисного метаболізму (ОМ) і перекисного окислення ліпідів (ПОЛ). Отримані дані оброблені методами статистики із застосуванням критерія Стьюдента.

\section{РЕЗУЛЬТАТИ}

Зміни показників гемодинаміки виявили, що до початку операції при проведенні епідуральної анестезії у пацієнтів основної групи достовірно $(\mathrm{p}<0,09)$ підвищувався ударний об'єм на $13 \%$ на тлі зниження загального периферичного опору судин на $20 \%$, при цьому хвилинний об'єм кровообігу мав тенденцію до збільшення. Дані зміни можна трактувати, як компенсаторно-пристосувальну реакцію з боку серцево-судинної системи. Підвищення концентрації в плазмі крові кортизолу на $81 \%(\mathrm{p}<0,05)$ i глюкози на $64 \%(p<0,05)$ на етапі травматизації було відзначено тільки у пацієнтів контрольної групи. Екскреція норадреналіну з сечею після закінчення операції в порівнянні з доопераційним рівнем збільшилася в основній групі на $22,2 \%(\mathrm{p}<0,05)$, в контрольній групі на 
$137 \%$ ( $<0,05)$. Така динаміка показників екскреції норадреналіну з сечею і концентрації в крові кортизолу з глюкозою вказує на велику ефективність антиноцицептивного захисту при комбінованому застосуванні БЗА + EA в порівнянні з використанням тільки методики БЗА. Аналіз динаміки ПОЛ і ОМ виявив, що після закінчення операції в контрольній групі, відбулося зменшення рівня вмісту ферментів антиоксидантного захисту на тлі збільшення кінцевого продукту метаболізму, в основній групі не відбувалося настільки виражених змін. Використанням ЕА в якості компонента анестезії попереджає активацію ПОЛ, та пошкодження клітинних мембран. Аналіз післяопераційних ускладнень виявив, що в основній групі частота гострого коронарного синдрому та пневмоній зменшилася відповідно в 1,7 і 1,8 рази, перистальтика кишківника відновлювалась в 1,5 рази швидше в порівнянні 3 контрольною групою. Результати свідчать, що включення ЕА до складу БЗА підвищує рівень антиноцицептивного захисту і попереджає виражену активацію гіпоталамо-гіпофізарно-адренокортикальної сістеми.

\section{ВИСНОВКИ}

EA і продовжену епідуральну аналгезію необхідно розглядати як ефективний метод знеболення та найважливіший лікувальний компонент інтенсивної терапії післяопераційного періоду, який істотно впливає на результати хірургічного лікування в цілому .

\section{Крутько Є.М. ${ }^{1}$, Проценко О.С. ${ }^{2}$, Черкаско Л.В. ${ }^{1}$, Шульга Є.В. ${ }^{2}$, Шульга М.В. ${ }^{1}$ \\ ПОРІВНЯННЯ ПРОВЕДЕННЯ ІНТРАОПЕРАЦІЙНОЇ АУТОГЕМОТРАНСФУЗІЇ ПО ВІДНОШЕННЮ ДО АЛОТРАНСФУЗІІ НА ПІДСТАВІ ІМУНОЛОГІЧНОГО СТАТУСУ

\author{
1 ДУ «Інститут медичної радіології ім. С.П. Григор'єва НАМН України», м. Харків \\ ${ }^{2}$ Харківський національний університет імені В.Н. Каразіна, м. Харків
}

\section{Вступ}

Кількість переливань крові пов'язано 3 довгостроковими небажаними явищами у вигляді алоімунізації, яка за літературними даними відзначається в $50-90 \%$ випадків (це пов'язано з наявністю лейкоцитів в трансфузованих компонентах крові, зокрема вплив Human Leukocyte Antigens-HLA). Величезний вплив гемотрансфузій на імунну систему, оскільки в даний час відкрито понад 400 групових антигенів еритроцитів, що веде до розвитку та поглиблення імунодефіциту. Аутологічні переливання мають багато побічних ефектів, в тому числі анафілактичний шок, можуть призводити до розвитку гострого пошкодження легень, інфекції, розладів згортання крові з подальшим гемолізом еритроцитів, розвитком гострої ниркової недостатності. Тому аутотрансфузія вважається більш безпечною, ніж алогенна трансфузія крові.

\section{МЕТА ДОСЛІДЖЕННЯ}

Оцінити, наскільки покращує інтраопераційна аутотрансфузія в порівнянні з алотрансфузією імунологічний статус під час оперативних втручань у онкохворих з мультиорганними оперативними втручаннями.

\section{МАТЕРІАЛИ ТА МЕТОДИ ДОСЛІДЖЕННЯ}

Пацієнти 3 мультиорганними оперативними втручаннями (32 (64\%) чоловіків і 18 (36\%) жінок) при прове- денні операцій на легенях і органах черевної порожнини; вік $42(35 ; 51)$ роки; тяжкість травми $32(28 ; 39)$ балів ISS) були рандомізовані на дві групи таким чином: ті, хто отримав аутологічну кров під час операції (група $\mathrm{A}, \mathrm{n}=22$ ) та ті, хто отримував аутотрансфузії (группа В, $\mathrm{n}=28$ ). Також вивчалася функція нирок шляхом дослідження клубочкової фільтрації. Статистична обробка результатів проводилась 3 використанням пакета програм Statistika 10. Як пороговий рівень статистичної значущості прийнято значення ймовірності $\mathrm{p}=0,05$.

РЕЗУЛЬТАТИ ДОСЛІДЖЕНЬ ТА ЇХ ОБГОВОРЕННЯ

У групі А, де пацієнти отримали аутологічну кров під час операції отримали зміст більш високих концентрацій интерлейкінов IL-8, IL-6 $(269,8 \mathrm{pg} / \mathrm{ml}, \mathrm{p}=0,020)$ в порівнянні з групою В (IL-6 131,78pg/ml, p=0,020).

\section{вИсновки}

У представленому дослідженні підтверджується, що періоперативні переливання алогенної крові можуть індукувати надмірний викид цитокінів і можуть завдавати шкоди. Інтраопераційна аутотрансфузія значно поліпшила імунологічний статус. Крім того, зменшення алогенного переливання крові може зменшити несприятливий вплив на функцію нирок.

\section{ДОСВІД ЗАСТОСУВАННЯ УЛЬТРАЗВУК-АСИСТОВАНИХ МЕТОДИК В АНЕСТЕЗІОЛОГІЧНІЙ ПРАКТИЦІ У ОНКОХВОРИХ}

Комунальний заклад "Клінічний онкологічний диспансер» ДОР», м. Дніпро, Україна

Актуальність

Сучасна анестезіологія та інтенсивна терапія базується на принципах мультимодальної аналгезії, безпеки та ефективності. Злоякісні новоутворення основних локалізацій розвиваються переважно у людей зрілого та похилого віку, які часто мають супутню патологію, переважно кардіальну, що є головною причиною розвитку фатальних ускладнень в періопераційному періоді. Онкологічні пацієнти також мають потребу в тривалому, комбінованому та комплексному лікуванні.

META РОБОТИ

Пошук нових методик з метою запобігання ускладнень та покращення результатів лікування онкохворих. 


\section{МАТЕРІАЛИ ТА МЕТОДІ}

32018 року нами впроваджені в практику BAIT№1 КЗ«КОД»ДОР» ультразвук-асистовані методики, які дали змогу безпечно та ефективно виконувати наступні лікувально-діагностичні процедури: ЕхоКГ, доплер вен нижніх кінцівок, пункції та катетеризації центральних та периферічних вен, блокади як компонент мультимодальної анестезії під контролем УЗ, оглядові УЗД органів черевної та грудної порожнин. Застосовували УЗ-апарат General Electric Logiq E.

\section{РЕЗУЛЬТАТИ}

Для покращення результатів хірургічного лікування онкологічних хворих було введено скринінгове ЕхоКГдослідження в передопераційному періоді з метою виявлення кардіальної патології. За 2019 рік проведено 500 скринінгових ЕхоКГ досліджень в передопераційному періоді, що допомогло нам обрати правильну тактику інфузійної та інтенсивної терапії. У 15,6\% хворих при скринінговому обстеженні була виявлена кардіальна патологія, що потребувало корекції передопераційного лікування.

Проведення доплер дослідження вен в передопераційному періоді дозволило нам своєчасно виявляти тромбози та попередити розвиток тромбоемболічних ускладнень.
Побічні дії хіміотерапії та гормонотерапії, наявність кахексії у онкохворих часто ускладнюють венозний доступ у наших пацієнтів. За 2019 рік у BAIT №1 проведено 150 пункцій та катетеризацій внутрішньої яремної вени під ультразвуковим контролем, що в $100 \%$ випадків дало позитивний результат, дозволило скоротити час процедури, зменшити кількість спроб пункцій та безпечно виконувати пункції хворим з тромбоцитопенією.

Мультимодальний підхід до знеболення є одною 3 ключових ланок ERAS-протоколу, що базується виключно на даних доказової медицини. У своїй практиці ми використовували пекторальну блокаду PECS blok, як компонент мультимодальної анестезії в онкохірургії молочної залози та TAP blok в онкогінекології. Застосування блоків під УЗ-контролем зменшує інтраопераційну потребу в наркотичних анальгетиках та потребу в анальгетиках після операції, дозволяє забезпечити ранню активізацію хворих, знижує частоту післяопераційної нудоти та блювання.

\section{ВИСНОВКИ}

Використання ультразвук-асистованих методик дозволило нам створити зручні умови передопераційного обстеження, візуалізувати сліпі методи катетеризації центральних вен та периферичних блокад, знизити рівень та вчасно діагностувати фатальні ускладнення, підвищити рівень безпеки пацієнта.

\title{
Лісун Ю.Б., Савченко С.О., Зуб Ю.М., Кішенко Ю.І.
}

\section{ПІДТРИМКА ВІТАМІННО-МІНЕРАЛЬНОГО СТАТУСУ ПІСЛЯ БАРІАТРИЧНИХ ВТРУЧАНЬ}

\author{
ДНУ «Центр інноваційних медичних технологій НАН України», м. Київ, Україна
}

В даний час розвинуті країни світу охопила справжня «епідемія» ожиріння. Згідно з даними ВООЗ близько двох мільярдів дорослого населення планети має надлишкову вагу, з них близько 650 мільйонів страждають на морбідне ожиріння.

Результати тривалого спостереження за цими пацієнтами показують, що незважаючи на застосування різних програм зниження ваги, що включали дієтотерапію, фармакотерапію та фізичні навантаження не призвели до зниження маси тіла, а навпаки було відмічено її збільшення. Баріатрична хірургія в даний час $\epsilon$ найефективнішим способом у боротьбі з ожирінням, що істотно зменшує частоту розвитку супутніх захворювань та смертність. Після баріатричних операцій спостерігається виникнення дефіциту вітамінів, мікроелементів та інших нутриєнтів різного ступеня тяжкості. Недостатність обумовлена післяопераційними анатомічними змінами кишківника (певні частини виключаються 3 процесу поглинання поживних речовин). Більш виражений дефіцит характерний для операцій комбінованого типу.
В ранньому післяопераційному періоді зниження рівня вітамінів в сироватці крові не супроводжуються характерними клінічними симптомами гіповітамінозу, що ускладнює діагностику та надання адекватної замісної терапії. В схемах лікування ми враховували, що мікроелементи та вітаміни конкурентно всмоктуються в певних відділах травної системи. Це є важливим фактором при корекції дефіцитних станів. Чергування введення цих препаратів, зменшує конкурентність поглинання, що призводить до покращення результату лікування. Щоб покращити всмоктування та мінімізувати побічні дії. в амбулаторних умовах доцільно рекомендувати прийом вітамінів та мікроелементів в різні дні тижня. При проведенні корекції дефіциту стаціонарного пацієнта доцільно частину препаратів вводити внутрішньовенно та внутрішньом'язово.

Виявлення ускладнень на їх початковому етапі дозволяє внести зміни в лікування, що в свою чергу знизить ризик виникнення декомпенсації стану та подальшої госпіталізації, зменшити фінансові затрати на лікування. 
Мазур А. П., Винниченко О. В.

\section{ВПЛИВ ВНУТРІШНЬОЧЕРЕВНОГО ТИСКУ НА ГАЗООБМІН І МЕХАНІКУ ДИХАННЯ У ПАЦІЄНТІВ 3 МОРБІДНИМ ОЖИРІННЯМ ПІД ЧАС ПРОВЕДЕННЯ ШТУЧНОӤ ВЕНТИЛЯЦІї ЛЕГЕНІВ}

Національний інститут хірургї і трансплантології ім. О. О. Шалімова НАМН України

\section{АКТУАЛЬНІСТЬ}

За даними ВОЗ у 2016 році понад 1,9 мільярда дорослих старше 18 років мали надлишкову вагу. У 2016 році близько $13 \%$ дорослого населення планети (11\% чоловіків і $15 \%$ жінок) страждали ожирінням.

Дихальні розлади- одна з головних проблем. Припускають, що причиною зниження залишкової ємності легенів під час операції у пацієнтів з МО є ВЧТ, за рахунок чого відбувається елевація купола діафрагми $[1,2,3]$. Пацієнти з МО мають хронічну внутрішньочеревну гіпертензію [4]. Відомо, що зниження еластичності грудної клітки призводить до зниження транспульмонального тиску і як наслідок до колапсу легенів [2]. Притік крові з черевної порожнини в грудну під час операції [5], підняття купола діафрагми при розкритті черевної стінки і фіксації ії на ребрах теж призводять до зменшення ДО $[6,7]$. Найголовнішим фактором $є$ підвищення ВЧТ, оскільки найчастіше після відкриття черевної порожнини зростають легеневий комплайнс і об'єми $[5,8]$.

\section{META}

Покращити результати штучної вентиляції легенів у пацієнтів з морбідним ожирінням.

\section{МАТЕРІАЛИ I МЕТОДИ}

В дане дослідження увійшло 81 хворих, яким було проведено лапаротомні баріатричні операції в Національному інституті хірургії і трансплантології ім. О. О. Шалімова в період з 2015 по 2018 роки: рукавна резекція шлунку - 55, гастрошунтування - 21 і біліопанкреатичне шунтування $з$ виключенням дванадцятипалої кишки за Hess- Marceo - 5 пацієнтів.

Серед хворих було 30 чоловіків (24,3\%) і 51 жінка (75,7\%). Середня вага становила $149,29 \pm 20,81$ кг. Середній вік пацієнтів становив $45,27 \pm 8,44$ роки. В структурі супутньої патології переважали артеріальна гіпертензія-81 пацієнт (100\%), ЦД 2 типу - 34 хворих (42\%), синдром обструктивного сонного апное -21 пацієнт (26\%).

Для проведення дослідження операція була поділена на три умовні етапи:

1. етап після інтубації і до виконання лапаротомії;

2. після розкриття черевної порожнини;

3. після ушивання лапаротомної рани.

На кожному з етапів проводилося вимірювання ВЧТ, $\mathrm{CAT}, \mathrm{PaO}_{2}$. Статистичний аналіз виконували з використанням SPSS версії 23. 0. Перемінні, які мали ненормальний розподіл, порівнювали з використанням U-тесту Мана-Уітні

\section{РЕЗУЛЬТАТИ}

Так у пацієнтів після інтубації рівень $\mathrm{PaO}_{2}$ складав в середньому $86,9 \pm \pm 24,1$ мм. рт. ст (мін. 67,8 мм рт. ст., макс. 146 мм рт. ст.,). Після лапаротомії показники $\mathrm{PaO}_{2}$ становили в середньому $121,3 \pm 25,2$ мм. рт. ст.( мін. 81 мм рт. ст.-макс. 183 мм. рт. ст.). Після ушивання черевної порожнини показники $\mathrm{PaO}_{2}$ варіювали від 60,7 до 92 мм рт. ст., в середньому $69,8 \pm 9,7$ мм рт. ст. У пацієнтів $\mathrm{PaO}_{2}$ були достовірно нижчими на етапі після ушивання черевної порожнини. ВЧГ в день операції діагностовано у 81 пацієнта.
Згідно класифікації WSACS на етапах операції 1 і 3 рівень ВЧТ відповідав першому ступеню ВЧГ, на етапі 2 ступінь ВЧГ знилися 3 другого до першого. На етапі 3 рівень ВЧТ був достовірно вищій, ніж на першому і другму етапі. $(\mathrm{P}=0,022)$. До розрізу черевної порожнини рівень ВЧТ склав в середньому $18,3 \pm 1,8$ мм рт. ст.( мін 15,9 м. рт. ст., макс.-19, 3 мм рт. ст.). після лапаротомії даний показник знизився в середньому до $15,1 \pm 2,5$ мм рт. ст.(мін. 11,5 мм рт. ст., макс.-17 мм рт. ст.). після ушивання черевної спостерігалося збільшення ВЧТ відносно вихідного рівня 21,3 $\pm 2,4$ мм рт. ст. (мін. 16,5 мм рт. ст., макс.25 мм рт. ст.). Після ушивання черевної порожнини рівні ВЧТ підвищилися у пацієнтів всіх трьох груп. Для оцінки рівня вісцеральної перфузії у всіх пацієнтів під час операції розраховувався АПТ. Для розрахунку АПТ використовували формулу АПТ=САТ-ВЧТ.

Між рівнем АПТ та рівнем $\mathrm{PaO}_{2}$ існує прямо пропорційний взаємозв'язок - при зростанні рівня АПТ спостерігається пропорційне збільшення рівня $\mathrm{PaO} 2-\mathrm{c}=0,01$ $(\mathrm{P}<0,05)$. Тобто, при підвищенні ВЧТ буде спостерігатися зниження $\mathrm{PaO}_{2}$, за умови стабільності показника CAT.

Показник САТ підтримувався протягом усієї операції.

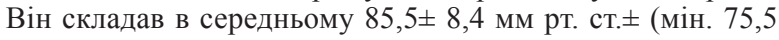
мм рт. ст., макс. 96,5 мм рт. ст.).

\section{вИСновки}

1.Хворі морбідним ожирінням мають хронічну внутрішньочеревну гіпертензію.

2. Рівень внутрішньочеревного тиску змінюється на різних етапах оперативного втручання.

3. Парціальна напруга кисню в артеріальній крові обернено-пропорційно залежить від рівня внутрішньочеревного тиску і прямо-пропорційно від рівня абдомінального перфузійного тиску.

\section{СПИСОК ЛІТЕРАТУРИ}

1. Buchwald H, Oien DM. Metabolic/bariatric surgery worldwide. Obes Surg. 2011 Apr; 23 (4):427-36.Doi: 10.1007/s11695-012-0864-0.

2. Malbrain ML, Chiumello D, Cesana BM, Reintam Blaser A, Starkopf $J$, Sugrue M, et al. A systematic review and individual patient data meta-analysis on intra-abdominal hypertension in critically ill patients: the wake-up project. World initiative on Abdominal Hypertension Epidemiology, a Unifying Project (WAKE-Up!). Minerva Anestesiol. 2014;80:293-306. PMID:24603146

3. Waele JJ, Malbrain MLNG, Kirkpatrick $A W$. The abdominal compartment syndrome: evolving concepts and future directions. Crit Care. $2015 ; 19: 211$. doi: 10.1186/s13054-015-0879-8.

4. Lambert DM, Marceau S, Forse RA. Intra-abdominal pressure in the morbidly obese. Obes Surg. 2005;15:1225-32. DOI:10.1381 096089205774512546

5. Jensen MD, Ryan DH, Apovian CM, Ard JD, Comuzzie AG, Donato $K A$, et al. AHA/ACC/TOS guideline for the management of overweight and obesity in adults: a report of the American College of Cardiology/American Heart Association Task Force on Practice Guidelines and The Obesity Society. J Am Coll Cardiol.

6. Kaw R, Pasupuleti V, Walker E, Ramaswamy A, Foldvary-Schafer $N$ Postoperative complications in patients with obstructive sleep oi:10.1378/chest.11-0283 Katyal N,Bollu PC.Ventilation, Obesity-Hypoventilation Syndrome.TreasureIsland (FL): StatPearls Publishing.-2018 Jan. PMID: 29493925

8. Singh M, Liao P, Kobah S, Wijeysundera DN, Shapiro C, Chung F. Proportion of surgical patients with undiagnosed obstructive sleep apnea. Br J Anaesth. 2013 Apr;110(4):629-636. doi: 10.1093/bja/ aes 465 
Мазур А. П., Гурін П. В., Бабіч М. М.

\title{
ПОРУШЕННЯ СИСТЕМИ КОАГУЛЯЦІЙНОГО ГЕМОСТАЗУ ПІД ЧАС КОРОНАРНОГО ШУНТУВАННЯ НА ПРАЦЮЮЧОМУ СЕРЦІ
}

\author{
ДУ «Національний інститут хірургії та трансплантології ім. О. О. Шалімова» НАМН України, м. Київ
}

\section{АКТУАЛЬНІСТЬ}

Внутрішньовенна інфузійна терапія кристалоїдними чи колоїдними розчинами під час оперативного втручання застосовується в основному під час крововтрати 3 метою відновлення гемодинамічної стабільності та адекватного внутрішньосудинного об' $є$ му для підвищення доставки кисню до тканин [1]. При введенні інфузійних розчинів у великих обєємах ініціюється розведення факторів згортання, що призводить до порушення коагуляції та коагулопатії $[2,3]$. Таким чином періопераційна крововтрата залежить не тільки від хірургічної техніки, а й від стану коагуляційного потенціалу крові. Тому існує зв'язок між періопераційною крововтратою та зниженням коагуляційного потенціалу, що може реєструватися в показниках тромбоеластограми при використанні колоїдних розчинів у порівнянні з кристалоїдними розчинами $[2,4]$. Вибір оптимального інфузійного розчину під час коронарного шунтування (КШ) на працюючому серці вважається досі не вирішеним питанням.

Мета. Дослідити зв€язок між застосуванням інфузійних розчинів та параметрами системи коагуляційного гемостазу під час планових операцій КШ на працюючому серці.

\section{МАТЕРІАЛИ I МЕТОДИ}

Проаналізовано результати обстеження та хірургічного лікування 80 пацієнтів, яким було виконано коронарне шунтування (КШ) на працюючому серці. Пацієнти були розділені на 2 групи: 1-шу (група дослідження) - 40 пацієнтів,які додатково були розділені на 2 рівні підгрупи по 20 пацієнтів (А та Б) - в інтраопераційному періоді застосовували колоїдні розчини (гідроксиетилкрохмалю (ГЕК) 130/0,4- підгрупа А, чи 4\% желатину - підгрупа Б); 2-гу (група порівняння) - 40 пацієнтів- в програму інфузійної терапії були включені лише кристалоїдні розчини. Проводили порівняння показників коагуляційного гемостазу, крововтрати, потребі у гемотрансфузії.

\section{РЕЗУЛЬТАТИ}

У пацієнтів підгрупи А у порівнянні з пацієнтами 2-і групи показники коагуляційного гемостазу на етапі закінчення операції виглядали наступним чином: протромбіно- вий час (ПЧ) - 20,6 $\pm 3,8$ сек. проти $18,5 \pm 2$ сек. ( $\mathrm{p}=0,04)$; протромбіновий індекс (ПІ) - 65,1 $\pm 12,1 \%$ проти $78,4 \pm 7,7 \%$ $(\mathrm{p}=0,0002) ;$ міжнародне нормалізоване відношення (МНB) - 1,76 $\pm 0,32$ проти $1,55 \pm 0,24(\mathrm{p}=0,02)$; clothing time $(\mathrm{CT})$ тромбоеластограми - 102,1 $\pm 15,4$ сек. проти $66,3 \pm 5$ сек. ( $\mathrm{p}=0,0001)$. Періопераційна крововтрата була вища у пацієнтів підгрупи А ніж у пацієнтів групи $2(615 \pm 191$ мл. та $438 \pm 62$ мл., $\mathrm{p}=0,0003) .3(15 \%)$ пацієнтів підгрупи А потребували трансфузії еритроцитарної маси. Пацієнти підгрупи Б у порівнянні 3 пацієнтами 2-ї групи мали наступні показники коагуляційного гемостазу: ПЧ - 20,2 $\pm 1,8$ сек. проти $18,5 \pm 2$ сек. $(\mathrm{p}=0,04)$; ПІ - 68,3 $\pm 6,9 \%$ проти

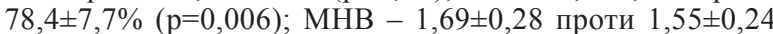
$(\mathrm{p}=0,006) ; \mathrm{CT}-132,8 \pm 38$ сек. проти $66,3 \pm 5$ сек. $(\mathrm{p}=0,0001)$. Інтраопераційна крововтрата у пацієнтів підгрупи Б склала $560 \pm 164$ мл. проти $438 \pm 62$ мл. у пацієнтів групи $2(\mathrm{p}=0,02)$. Гемотрансфузії в періопераційному періоді не потребував жоден пацієнт підгрупи Б.

\section{вИСновкИ}

Застосування колоїдних розчинів при планових операціях КШ на працюючому серці призводить до порушень коагуляційного гемостазу, збільшення періопераційної крововтрати та потребі у гемотрансфузії.

\section{кЛючОВІ СЛОВА}

Коагуляційний гемостаз, колоїдні розчини, крововтрата, гемотрансфузія.

\section{СПИСОК ЛІТЕРАТУРИ}

1. YanalaUR, Johanning JM, Pipinos II, High RR, Larsen G, Velander WH, Carlson MA.Fluid administration rate for uncontrolled
intraabdominal hemorrhage in swine. PLoS One. 2018 Nov intraabdominal hemorrhage in swine. PLoS One. 2018 29;13(11):e0207708. doi: 10.1371/journal.pone.0207708.

2. Rasmussen K, Johansson P, Hoejskov M, Kridina I, Kistorp T, ThindP,e al. Hydroxyethyl starch reduces coagulation competence and increase blood loss during major surgery. Results from a randomized controlled trial. Ann Surg 2014; 2:249-254. doi:10.1097/SLA.0000000000000267 3. Hung MH, Zou C, Lin FS, Lin CJ, Chan KC, Chen Y. New 6\% hydroxyethyl starch 130/0.4 does not increase blood loss during major abdominal surgery - a randomized, controlled trial. J Formos Med Assoc 2014; 113:429-435. doi:10.1016/j.jfma.2012.08.002

4. Rasmussen K, Secher N, Pedersen T.Effect of perioperative colloid and crystalloid fluid therapy on coagulation competence, haemorrhage and outcome: A systematic review and stratified metaanalysis. Medicine (Baltimore). 2016 Aug;95(31):1-10. doi: 10.1097 MD.0000000000004498.

\section{Матолінець Н.В.}

\section{ДИНАМІКА РІВНІВ ГАЗОТРАНСМІТЕРІВ У ЛІЗАТІ ЛІМФОЦИТІВ В ГОСТРОМУ ПЕРІОДІ ПОЛІТРАВМИ}

Львівський національний медичний університет імені Данила Галицького

\section{АКТУАЛЬНІСТЬ ПРОБЛЕМИ}

Тяжка механічна травма викликає стрімку активацію і швидке виснаження всіх регуляторних функцій організму з розладами гомеостазу, метаболізму та енергозабезпечення клітин. Пошкодження тканин призводить до активації системного запальної відповіді та формування ендотеліальної дисфункції з наслідками патологічного процесу для різних органів і систем $[1,2]$. Провідну роль у цьому механізмі відіграють лімфоцити, макрофаги, нейтрофіли та ендотеліоцити, які у відповідь на травматичне пошкодження, змінюють продукцію регулюючих газоподібних месенджерів [3]. Оксид азоту (NO) вважається вирішальною сигнальною і ефекторною молекулою в ряді біологічних процесів, які відіграють важливу роль у формуванні ендотеліальної дисфункції. NO, який утворюється у великих кількостях під час травматичного пошкодження тка- 
нин, пов'язаний з підвищеною експресією індукованої ізоформи NO-синтази (iNOS) [4]. Другим важливим газотрансмітером є сірководень (H2S), який має протизапальну, антиапоптозну і проангіогенну дію і регулює модулюючу активність ендотеліальної NO-синтази (eNOS). H2S відіграє ключову роль у захисті тканин від травм, оскільки сприяє їх репарації, одночасно знижуючи запальну відповідь [5].

\section{META РОБОТИ}

Оцінити динаміку рівнів NO, NO-синтази (NOS), iNOS, eNOS, H2S в лізаті лімфоцитів у пацієнтів на момент госпіталізації та через 24 години після отриманої травми.

\section{МАТЕРІАЛИ ТА МЕТОДИ}

Проведений аналіз даних клінічного обстеження і лікування 30 хворих 3 політравмою, доставлених у відділення анестезіології та інтенсивної терапії (BАIT) КНП «Клінічної лікарні швидкої допомоги м. Львова» в середньому через 0,5 години після травми. Середній вік постраждалих складав $48,4 \pm 5,2$ років. Пацієнтам проводили лабораторні дослідження вмісту $\mathrm{NO}, \mathrm{NO}-$ синтази, індукованої NO-синтази, ендотеліальної NO-синтази, $\mathrm{H} 2 \mathrm{~S}$ в лізат лімфоцитів у пацієнтів на момент госпіталізації та через 24 години після травми.

\section{РЕЗУЛЬТАТИ}

Встановлені статистично достовірні відмінності в рівнях NO, NOS, iNOS i eNOS, H2S в лізаті лімфоцитів на момент госпіталізації та через 24 години після політравми. 3 перших годин після політравми реєструвалось статистично значуще зниження рівня $\mathrm{NO}$ в лізаті лімфоцитів в 1,4 рази від норми за рахунок підвищення деградації, пригнічення експресії та інактивації ендотеліальної NOсинтази, а також зниження його синтезу. Рівень оксиду азоту в лізаті лімфоцитів підвищувався після 24-годинної інтенсивної терапії з $0,38 \pm 0,01$ до $0,47 \pm 0,02$ мкмоль /л, $(\mathrm{p}<0,01)$.

Результати дослідження продемонстрували значне підвищення рівня NO-синтази з $0,311 \pm 0,016$ до $0,489 \pm$ 0,021 нмоль / хв Ч мл $(\mathrm{p}<0,01)$, за рахунок збільшення рівня, як iNOS, так i eNOS. При цьому, звертає на себе увагу зміна відношення iNOS до eNOS, а саме, збільшення iNOS у пропорції від 14,2 $\pm 1,1 \%$ на початку лікування до $21,9 \pm 1,0 \%$ через 24 години після травми (рівень eNOS збільшився в 1,36 рази з $0,268 \pm 0,015$ до $0,371 \pm$ 0,016 нмоль / хв Ч мл $(\mathrm{p}<0,01)$, а рівень $\mathrm{NNOS}$ показав найбільший приріст - у 2,63 рази з $0,043 \pm 0,004$ до $0,111 \pm$ 0,008 нмоль / хв Ч мл $(\mathrm{p}<0,01)$. Встановлена позитивна кореляція між NOS i iNOS $(r=0,45)$ i між NOS i eNOS $(\mathrm{r}=0,97)$, які залишалися високими протягом першого дня після політравми.

На цьому тлі рівні $\mathrm{H} 2 \mathrm{~S}$ знизилися з $80,75 \pm 1,87$ до $70,57 \pm 1,98$ мкмоль/л $(\mathrm{p}<0,01)$. Встановлена негативна кореляція вмісту $\mathrm{H} 2 \mathrm{~S}$ і активності $\mathrm{NO}$-синтази, що вказує на регуляторний вплив даного газотрансмітера на активність фермента.

\section{висновки}

У гострому періоді політравми відбувається зростання рівнів індукованої та ендотеліальної NO-синтази в лізаті лімфоцитів, проте відмічається значне відсоткове переважання збільшення iNOS над eNOS.

Протягом першого дня політравми спостерігається достовірне зниження вмісту $\mathrm{H} 2 \mathrm{~S}$, що може свідчити про дисбаланс між прозапальними ефектами iNOS і протизапальною дією $\mathrm{H} 2 \mathrm{~S}$.

\section{ключовІ слОвА} $\mathrm{H} 2 \mathrm{~S}$.

Політравма, лімфоцити крові, NO, NOS, iNOS, eNOS,

\section{СПИСОК ЛІТЕРАТУРИ}

1. Lausevic Z, Lausevic M, Trbojevic-Stankovic J, Krstic S, Stojimirovic $B$. Predicting multiple organ failure in patients with severe trauma. Can J Surg. 2008;51:97-102.

2. Trance SD, Petrieor CL, Hagzu N. Biomarkers in polytrauma induced systemic inflammatory response syndrome and sepsis - a narrative review. Romanian journal of anaesthesia and intensive care. $2014 ; 21(2): 118-122$

3. Матолінець Н.В. Роль газотрансмітерів у патогенезі органноі дисфункиії при політравмі / Медицина невідкладних станів. 2018. - №3(90). - C.33-39.

4. Matolinets $N$, Sklyarova $H$, Sklyarov A. Nitric oxide and hydrogen sulfide - markers of acute period of polytrauma. Wiadomosci sulfide - markers of acute peri

5. Lo Faro ML, Fox B, Whatmore JL, Winyard $P G$ and Whiteman M. Hydrogen sulfide and nitric oxide interactions in inflammation. Nitric Oxide. 2014; 41:38-47.

УДК: 616.131-005.7-085

Муризіна О.Ю.

\section{ВИЗНАЧЕННЯ ГЕМОДИНАМІЧНОÏ НЕСТАБІЛЬНОСТІ У ПАЦІЄНТІВ 3 ГОСТРОЮ ТЕЛА ВИСОКОГО ПРОМІЖНОГО РИЗИКУ}

\section{ДЗ «Дніпропетровська медична академія МОз України», кафедра анестезіології, інтенсивної терапії} та медицини невідкладних станів ФПО

\section{АКТУАЛЬНІСТЬ ПРОБЛЕМИ}

Гостра ТЕЛА здатна спричинити дисфункцію правого шлуночка (ПШ) - самостійного ключового прогностичного чинника несприятливого госпітального результату і в загальній популяції, і у пацієнтів зі стабільними гемодинамічними показниками [1]. За Рекомендаціями ESC 2014 у пацієнтів, що не мають шоку чи гіпотензії, в гостру фазу ТЕЛА не рекомендовано (IIIB) рутинне застосування первинного системного тромболізису (ТЛТ). Сучасні принципи узгоджують стратегію ефективної антикоагуляції і початкового гемодинамічного моніторингу («пильного очікування»), особливо протягом перших 48-72 годин, у пацієнтів 3 проміжним ризиком, із зазначенням на «рятівний» ТЛТ, якщо з'являються ознаки гемодинамічної декомпенсації $[1,2]$.

\section{META РОБОТИ}

Виявити ранні прояви гемодинамічної декомпенсації і обгрунтувати доцільність системної ТЛТ у нормотензивних пацієнтів з гострою ТЕЛА високого проміжного ризику для своєчасного започаткування екстреної реперфузійної терапії (IB).

\section{МАТЕРІАЛИ ТА МЕТОДИ}

Представлені результати контрольованого проспективного нерандомізованого дослідження, заснованого на даних лікування 45 пацієнтів 3 первинним епізодом гострої ТЕЛА і проведеним ТЛТ у ВІТ №1 КЗ «КОШМД». Досліджувана вибірка: 29 (64\%) чоловіків і 16 (36\%) жінок, віком - 55, $6 \pm 13,6$ років. «Терапевтичне вікно» від 1 до 4 діб. Критерії включення: пацієнти високого і високого-проміжного ризику з гострою ТЕЛА, підтвердже- 
ною КТ-ангіографією, результати якої вказували на наявність тромбу щонайменше сегментарного, навіть більш проксимального рівня. Діагностичну і лікувальну програму здійснено відповідно до европейських (ESC 2014) і вітчизняних (2016) рекомендацій з ведення гострої ТЕЛА. Обробку результатів проведено у середовищі аналізу даних «Statistica» (StatSoft, 6.1).

Групи розподілені методом визначення ризику ранньої смерті: 1-а група $(\mathrm{n}=28)$ - пацієнти 3 гострою ТЕЛА високого ризику, з гіпотонією або епізодом syncope. 2-а група $(\mathrm{n}=17)$ - нормотензивні пацієнти 3 гострою ТЕЛА високого-проміжного ризику. Тяжкість TEЛА за PESI: 1-й групі - $152 \pm 19$ балів, у 2-й - 138 $\pm 9,7$ в межах об'єднаних IV i V класів $\left(\mathrm{U}_{1,}=1,4, \mathrm{p}<0,01\right)$. Пацієнтів 3 перебігом шоку, зумовленого ТЕЛА, не включено до представленого аналізу.

\section{РЕЗУЛЬТАТИ}

За даними первісної діагностичної МДКТ розміри ПШ були більшими $(\mathrm{U}=3,0, \mathrm{p} € 0,05)$ у 1 групі - 44,3 (42-55) проти $41,5,(38,551)$ мм у 2 групі, а ширина стовбура ЛА була напроти гіранично меншою $(\mathrm{U}=3,8, \mathrm{p}<0,05)-28,5$ (23 28) та $32,5(30,534,7)$ мм. В обох групах були подібними: ширина лівогं шлуночка (ЛШ) - 31 (28-47) мм $(\mathrm{U}=31,5, \mathrm{p}=0,89)$, лівої ЛА - 24,8, (23ч28) мм (U=14,5, $\mathrm{p}=0,85$ ).

За даними ЕхоКГ визначено первісне патологічне збільшення правих відділів серця, систолічного тиску у ЛА (СТЛА) і кінцево-діастолічного об'єму ЛШ (КДО) зі збереженням фракції викиду - ФВ ЛШ. СТЛА збільшений до 50-55 мм рт.ст. (31 80; $\mathrm{U}=11,5, \mathrm{p}=0,76)$ при референтних значеннях меншихх, ніж 20 мм рт.ст., КДО - до 93,5 мл (62 122, $\left.\mathrm{U}_{1-2}=26, \mathrm{p}=0,44\right)$ при належних5575 мл. Внххідна ФВ дорівнювала $61 \%$ [ 5965$] \%$ за Тейхольцем $\left(\mathrm{U}_{1-2}=33,5, \mathrm{p}=0,34\right)$; ударний індеке (УI) незначно перевищував нижню референтну межу (25 50)34,1 мл/м² (32 36; $\left.\mathrm{U}_{1-2}=18,5, \mathrm{p}=0,45\right)$. Діастолічнийрозмір
ПШ збільшеннай до 2,85-3 см (2,85 3,2, $\left.\mathrm{U}_{1-2}=35,5, \mathrm{p}=0,96\right)$ і достовірно перевищував верхін референтну межу $(0,52$ см). Площа правого передсердя (ПП) $-17,5-18,8$ $\mathrm{cm}^{2}\left(-15,219,8, \mathrm{U}_{1-2}=46, \mathrm{p}=0,44\right)$, а індекс площі ПП (ІПП) $-8,30-9,05$ (7,5 9,9, $\left.\mathrm{U}_{1-2}=34, \mathrm{p}=0,28\right)$, що співвідносилося 3 верхніми реंферентними значеннями. Ознакою щодо збільшення перенавантаження на серце було підвищення КДО до 94 мл (62 110; $\left.\mathrm{U}_{1-2}=26, \mathrm{p}=0,44\right)$.

Повторна ЕхоКҒ проведена через 8-10 діб, відобразила сприятливі зміни у параметрах ЦГ: СТЛА зменшився майже у два рази $(Z=2,48, p<0,01)$ до 26,4-27 [23 32] мм рт.ст., $\left(\mathrm{U}_{1-2}=10,2, \mathrm{p}=0,81\right)$, при певному (у $11 \%$; $)$ зменшенні $(\mathrm{Z}=2,58, \mathrm{p}<0,01)$ розміру ПШ до $2,8[2,63,0] \mathrm{cm}$ $\left(\mathrm{U}_{1-2}=45,2, \mathrm{p}=0,77\right)$, при цьому ФВ збільшилася $\div(\mathrm{Z}=2,31$, $\mathrm{p}=0,018)$ до $64[55,7 \quad 68] \%\left(\mathrm{U}_{1-2}=34,5, \mathrm{p}=0,15\right)$, У I $(\mathrm{Z}=2,81, \mathrm{p}<0,001)-$ до $\div 34,5\left[\begin{array}{ll}32 & 39\end{array}\right]$ мл $/ \mathrm{M}^{2}\left(\mathrm{U}_{1}=16,5\right.$, $\mathrm{p}=0,53)$. КДО сприятливо знизивс匇 $(\mathrm{Z}=2,14, \mathrm{p}=0,02)$ - до $80\left(\begin{array}{ll}60 & 89\end{array}\right) \mathrm{mL} / \mathrm{m}^{2}\left(\mathrm{U}_{1-2}=29, \mathrm{p}=0,27\right)$, проте ще перевищуючи вёрхню референтну межу $-78 \pm 7 \mathrm{~mL} / \mathrm{m}^{2}$.

\section{ВИСНОВКИ}

Прихована гемодинамічна нестабільність у нормотензивних пацієнтів 3 гострою ТЕЛА високого проміжного ризику проявляться у первісному патологічному збільшенні правих відділів серця, систолічного тиску у ЛА (СТЛА) і кінцево-діастолічного об'єму ЛШ (КДО) зі збереженням фракції викиду, що визначає дисфункцію правого шлуночка і засвідчує ризик ранньої гемодинамічної декомпенсації, подібну до цензурованої групи високого ризику, зумовлюючи доцільність проведення «рятівної» ТЛТ.

\section{СПИСОК ЛІТЕРАТУРИ}

1. Konstantinides SV, Barco S. Systemic thrombolytic therapy for acute pulmonary embolism: who is a candidate? // Semin Respir Crit Care pulmonary embolism: who is a candidate? 2. Igneri LA, Hammer JM. Systemic thrombolytic therapy for massive and submassive pulmonary embolism // J Pharm Pract. - 2018 - Vol. 1:897190018767769. doi: 10.1177/0897190018767769.

Науменко В.О., Волкова Ю.В., Майсурадзе А.О.

\title{
ЗАСТОСУВАННЯ МЕГЛЮМІНУ НАТРІЮ СУКЦИНАТУ У ХВОРИХ 3 МЕТАБОЛІЧНИМ СИНДРОМОМ У ПІСЛЯОПЕРАЦІЙНОМУ ПЕРІОДІ
}

\author{
Харківський національний медичний університет
}

\section{АКТУАЛЬНІСТЬ}

Проблема підготовки пацієнтів з супутнім ожирінням та метаболічним синдромом до оперативних втручань та їх періопераційне забезпечення набуває все більшої актуальності у зв'язку з значним зростанням кількості пацієнтів з цим видом патології та збільшенням питомої ваги пацієнтів досить молодого віку серед цієї групи [2]. Одним 3 шляхів впливу на перебіг періопераційного процесу є включення до схеми післяопераційної інтенсивної терапії меглюміну натрію сукцинату, що завдяки посиленню компенсаторної активації анаеробного гліколізу та зниженню ступеня пригнічення окислювальних процесів в циклі Кребса у дихальному ланцюгу мітохондрій клітин підвищує внутрішньоклітинний фонд макроергічних сполук аденозинтрифосфатаз креатинфосфата, що значно стабілізує стан гепатоцитів, кардіоміоцитів та багатьох інших клітин організму [3].

\section{META}

Оптимізація періопераційної інтенсивної терапії у хворих $з$ ожирінням в ургентній хірургії.

\section{МАТЕРІАЛИ ТА МЕТОДИ}

Обстежено 38 хворих, оперованих в ургентному порядку віком від 24 до 66 років 3 приводу абдомінальної хірургічної патології, що мали надлишкову вагу (IMT > $\left.28 \mathrm{\kappa r} / \mathrm{M}^{2}\right)$ та ознаки метаболічного синдрому. Контрольна група та група пацієнтів, у яких застосовувався в післяопераційному періоді меглюмін натрію сукцинат 600-800 мл/добу. Проводилися клініко-лабораторне обстеження визначення реакцій на стрес за допомогою оцінки змін електронегативності ядер клітин буккального епітелію [4, 5], визначення когнітивних функцій за шкалою MMSE та таблиці Шульте, оцінка балансу вегетативної нервової системи за допомогою інтервалокардіографії [1]. Досліджувався вихідний стан когнітивних функцій та показників 
вегетативної нервової системи, стан на третю добу після операції та при переводі з відділення інтенсивної терапії. Результати оцінювалися з використанням параметричних методів статистики 3 використанням t-критерію Стьюдента.

\section{РЕЗУЛЬТАТИ}

Хворі за вихідним соматичним станом та характером хірургічної патології і типом хірургічного втручання у групах статистично не відрізнялися. У пацієнтів контрольної групи на третю добу післяопераційного періоду відзначалося зниження когнітивних функцій в середньому на 14,2-14,8 \%, зменшувалася кількість клітин буккального епітелію, ядра яких мали електронегативний заряд на 22-28 \% та відзначалося зростання відхилень при аналізі кардіоінтервалограми у бік напруження вегетативної нервової системи 18,2-18,8 \%. Ці зміни спостерігалися протягом усього періоду знаходження у BPIT. У групі, яка отримувала меглюмін натрію сукцинат, зниження когнітивних функцій на третю добу післяопераційного періоду не перевищувало 9,2-9,9 \%, відхилення електронегативності ядер клітин буккального епітелію 16,5-17,0 \% зростання напруження балансу вегетативної нервової системи 13,4-14,2 \% при переводі з ВРІТ нормалізація досліджуваних показників втричі перевищувала таку у контрольній групі.

\section{висновки}

Використання меглюміну натрію сукцинату у комплексній інтенсивній терапії післяопераційного періоду у хворих з метаболічним синдромом доцільно та якісно впливає на покращення лікування цієї групи хворих.

\section{СПИСОК ЛІТЕРАТУРИ}

1. Баевский Р.М., Кирилов О.И. Математический анализ изменений сердечного ритма при стрессе. - М., 1984

2. Грии Е.С., Сидоренко В.Н. Особенности ведения паииентов хирургического профиля с сопутствующим метаболическим синдромом в гинекологической практике / Е.С. Гриц В.Н. Сидоренко ромом в гинекологической практике / Е.С. Грии, В.Н. Сидоренко

3. Мосенцев ГФ и соавт. Альтернативные компоненты - 139-143 мосенцев Г.Ф. и соавт. Альтернативные компоненты коррекции микрочиркулятор

4. Шахбазов В.Г., Григорьева Н.Н., Колупаева Т.В. Новый иитобиоШахбазов В.Г., Грикорьева Н.н., Колупаева Т.в. Новый цитобиологический показатель физиологического состояния органили

менко В.А. Электроотрицательный заряд клеи критерий напряженности стрессорных реакиий в амбулаторной анестезиологии / Біль, знеболювання і інтенсивна терапія. 2003. - № 4. - C. 64-69

\title{
Науменко В.О., Волкова Ю.В.
}

\section{МЕТОД ОЦІНКИ СТУПЕНЮ ВИРАЖЕНОСТІ СТРЕСОВИХ РЕАКЦІЙ ПРИ АНЕСТЕЗІОЛОГІЧНОМУ СУПРОВОДІ СТОМАТОЛОГІЧНИХ ОПЕРАЦІЙ В АМБУЛАТОРНІЙ ПРАКТИЦІ}

\author{
Харківський національний медичний університет
}

\section{АКТУАЛЬНІСТЬ}

Рішення задачі зниження кількості побічних ефектів та ускладнень тотальної внутрішньовенної анестезії напряму залежить не тільки від вибору анестетика, але й від його введеної кількості [4]. Традиційний розрахунок дози в масово-кількісному співвідношенні (мг/кг) може бути скориговано з урахуванням рівня передопераційного стресу, ступеню розвитку, який $є$ індивідуальним для кожного пацієнта [2]. В якості метода об’єктивного контролю рівня стресу був апробований мікроелектрофорез на клітинах буккального епітелію. Буккальный епітелій $\epsilon$ одним 3 найбільш мобільних й активних видів тканин цілісного організму, який реагує на зовнішній вплив $[1$, 5]. Кількість клітин $з$ електрично активними ядрами залежить від віку та фізіологічного стану організму, до якого в повній мірі можна віднести й передопераційний стрес [3].

\section{МЕТАРОБОТИ}

Пошук та апробація нових об'єктивних методик контролю рівня стресорності впливу, який впливає в ході стоматологічних операцій по встановленню зубних імплантатів, які виконуються в стаціонарі «одного дня», в умовах тотальної внутрішньовенної анестезії пропофолом (TBA).

\section{МАТЕРІАЛИ ТА МЕТОДИ}

Дослідження проведені у 82 хворих у віці від 42 до 65 років. Мазок з внутрішньої поверхні щоки поміщали в камеру с буферним розчином $(\mathrm{pH}=7,0)$, подальший підрахунок електронегативних ядер (ЕОЯ) проводили за методикою Шахбазова В.Г. та Колупаєвой Т.В. 3 допомогою прибору «Біотест-2». Розраховували ЕОЯ нормовану віковій нормі:

$$
\text { ЕОЯ }_{\mathrm{N}}=\frac{\text { ЕОЯ фактичне }}{\text { вікова норма ЕОЯ }} \text {. }
$$

Дослідження проводилось доопераційно при огляді пацієнта анестезіологом виявлялись рівні кортизолу та глюкози у сироватці крові.

\section{РЕЗУЛЬТАТИ}

Після обробки результатів пацієнти розподілялися на 3 групи напруженості стресорних реакцій (НСР): низька $\mathrm{EO}_{\mathrm{N}}=100,33 \pm 6,91 \%$; помірна $\mathrm{EO}_{\mathrm{N}}=111,00 \pm 7,31 \%$ i висока $\mathrm{EOЯ}_{\mathrm{N}}=122,27 \pm 10,62 \%$, що додатково підтверджено дослідженнями рівней кортизолу та глюкози в сироватці крові. Це відображає мобілізацію стресорних систем, покликаних захищати організм від агресивних впливів.

\section{вИСновки}

Значні зміни ЕОЯ на етапі очікування операції у ряду пацієнтів корелює з високим рівнем стресорності в передопераційний період. Виявлена кореляція між змінами ЕОЯ та іншими показниками напруження стресорних систем (рівень кортизолу та глюкози в сироватці крові). Метод $\epsilon$ неінвазивним, малотравматичним і достатньо швидким за часом виконування (результат можна отримати вже через 10 хвилин, після взяття мазка).

\section{ПЕРСПЕКТИВИ ПОДАЛЬШИХ ДОСЛІДЖЕНЬ}

Передбачається провести порівняльний аналіз впливу різноманітних дозувань анестетика в залежності від передопераційного показника ЕОЯ з метою індивідуалізації підбору дози анестетика та зниження кількості ускладнень ТВА в амбулаторній стоматологічній практиці.

\section{ЛITEPATУPA}

1. А.с. №1169614 СССР, Способ определения биологического возра ста человека / Шахбазов В.Г., Колупаева Т.В.; Бюллетень изобреста человека Шахбазов

2. Ганина К.П., Полищук Л.З., Бородай Н.В. Цитологическая реактивность онкологического больного. - Киев: Наукова думка. тивность онко 
К.А. Колганова, В.А. Пайкуи, І.В. Васильєва // Київ: Медицина не відкладних станів. - 2018. - №8(95). - С.19-30

5. Шахбазов В.Г., Григорьева Н.Н., Колупаева Т.В. Новый иитобиологический показатель физиологического состояния организма человека / Физиология человека. - 1996. - T.22, - С.71-75

\section{УДК 616.98.06:578.89:615.33-089-08 \\ Нестеренко А.Н., Прокопенко Б.Б., Климик Н.А., Нестеренко Е.А. \\ ПОСТОЯННЫЙ ЛОКАЛЬНЫЙ МИКРОБИОЛОГИЧЕСКИЙ МОНИТОРИНГ (ЛММ) ВОЗБУДИТЕЛЕЙ ГОСПИТАЛЬНОЙ ХИРУРГИЧЕСКОЙ ИНФЕКЦИИ (ГХИ) КОНКРЕТНЫХ ОТДЕЛЕНИЙ - КЛЮЧЕВОЙ ФАКТОР ВЫБОРА АДЕКВАТНОЙ СТАРТОВОЙ ЭМПИРИЧЕСКОЙ АНТИБИОТИКОТЕРАПИИ (АБТ)}

Донецкий национальный медицинский университет МЗ Украины, Краматорск

ЦЕЛЬ

Обосновать выбор препаратов стартовой эмпирической АБТ ГХИ в отделениях хирургического профиля (ОХП) областных и городских клинических больниц (КБ) Краматорска.

\section{МАТЕРИАЛЫ И МЕТОДЫ}

Выполнен ретроспективный (VII.2015-VI.2018) анализ результатов ЛММ - высевов 2402 изолятов патогенов $(Г р+1769 / 73,6 \% ;$ Гр€ 633/26,4\%) в т.ч. 571 изолятов ESKAPE - Staphylococcus aureus (MRSA), Klebsiella pneumoniae, Acinetobacter baumannii, Pseudomonas aeruginosa, Enterobacter spр при исследовании крови на стерильность, отделяемого ран, дренажей пациентов 1-2 хирургических отделений ГКБ №1; травматологического, ожогового отделений ГКБ №3; хирургического отделения онкодиспансера; урологического отделения ГКБ №2; областных: перинатального центра, центра кардио- и рентген-эндоваскулярной хирургии, отделения гемодиализа, взятых спустя 48 часов после госпитализации с выделением изолятов в количестве не менее $10^{5} \mathrm{KOЕ/мл.} \mathrm{Использо-}$ вали диско-диффузионный и метод серийных разведений (VITEK ${ }^{\circledR} 2$ compact, bioMerieux Inc) с обработкой данных (WHONET,v.5.6). Чувствительность патогенов к АБ-препаратам учитывали, если данные были представлены в е" $75 \%$ наблюдений.

\section{РЕЗУЛЬТАТЫ}

Среди патогенов ГХИ за периоды VII.2015-VI.2018 доминировал род Staphylococcus (S.aureus; S.epidermidis; S.coagulase negative; S.haemolyticus). Среди ESKAPE патогенов - MRSA -216 высевов, чувствительных к тобрамицину (Тоб) 84,6/100\%/-; амикацину (Амк) -/93,8\%/-; гентамицину (Ген) -/83,3/92,9\%; клиндамицину (Кли) 72/83,3/ -\%; ванкомицину (Ван) 69,2/75,8/ 14,3\%; левофлоксацину (Лвф) -/41,2/77,8\%; меропенему (Мер) - /15,8\%/-; имипенему (Ипм) -/11,8\%/-. На II месте A.baumannii - 155 высевов, чувствительных: к Ген 100/66,7\%/-; Тоб 79,4/ 84,6/60\%; Амк 55,6/83,3\%; Лвф 56,8/51,7/60\%; Мер 41,7/ $88,9 / 33,3 \%$; Ипм 33,3/56\%/-; цефтриаксону (Цтр) 23,8/ 45,9\%/-. На III - K.pneumoniae - 70 высевов, чувствительных: к Ген 100/75/100\%; Амк 64,3/55,6/66,7\%; Тоб 60/ 75\%/-; Мер 60/62,5/66,7\%; Лвф 41,2/42,9/57,1\%; Цтр 50/ 41,7/85,7\%; Ha IV - Enterobacter spp 66 высевов, чувствительных: к Ген 90/83,3/66,7\%; Амк 38,5/80\%/; Мер 50/ $88,9 \% /-$; Цтр $35,3 / 44,4 / 60 \%$; Имп $20 / 50 \% /-$; на V Ps.aeruginosa $€ 64$ высева, чувствительных: к Тоб 83,3/-/ 71,4\%; Ген 75/-/50\%; Цтр 56,2/50/20\%; Мер 42,9/57,1/ 66,7\%; Лвф 42,1/75\%/-; Ипм 40/12,5\% - E.faecium высеян не был.

За VII.2015-VI.2018 динамика доли ESKAPE в пуле госпитальных патогенов составила: 27,2-27,9-13,9\%. Отмечена тенденция к росту доли патогенов рода Staphylococcus: $67,8-71,2-78,3 \%$, a 25.05.2019 в Краматорске впервые выделен линезолид-резистентный штамм MRSA.

\section{выводы}

Выбор препарата или их комбинации для стартовой эмпирической и целенаправленной АБ-терапии ГХИ обеспечивает постоянный ЛММ ОХП, позволяющий выявить клинически значимые возбудители госпитальной хирургической инфекции и степень их АБ-резистентности.

\section{СПИСОК ЛИТЕРАТУРЫ}

1. Эпиднадзор за устойчивостью $к$ противомикробным препара там в Центральной Азии и Восточной Европе. Ежегодный доктам в Центральной Азии и Восточной Европе. Ежегодный доклад 2018. Женева: ВО3; 2019. - 167 с. [Электронный ресурс]. - Режим docmyna: http://apps. who.int/medicinedocs/documents s22246ru/s22246ru.pdf

2. No Time to Wait: Securing the future from drug-resistant infections. 2019 Report to the Secretary-General of the United Nations. Antimicrobial resistance UN Interagency Coordination Group on Antimicrobial Resistance. 25 р. [Электронный ресурс]. - Режим docmyna: https://www.who.int/antimicrobial-resistance/interagencycoordination-group/IACG final report EN.pdf? ua $=1$.

УДК: 616.6-089.819-089.5]-042.2

Овсієнко Т.В., Лоскутов О.А., Бондар М.В.

\section{ВИКОРИСТАННЯ МУЛЬТИМОДАЛЬНОЇ МАЛООПІОЇДНОЇ АНЕСТЕЗІЇ ПРИ ПРОВЕДЕННІ ЛАПАРОСКОПІЧНИХ ОПЕРАТИВНИХ ВТРУЧАНЬ HA НИРКАХ}

\section{АКТУАЛЬНІСТЬ}

Використання рутинних доз опіоїдів при проведенні оперативних втручань має ряд небажаних побічних ефектів таких як п/о гіпералгезія, центральна депресія дихання, парез кишківника, і т.д. [1]. Це дуже актуально для пацієнтів 3 уже скомпрометованою функцією нирок, у зв'язку з уповільненою елімінацією лікарських препаратів [2, 3].

\section{META РОБОТИ}

Визначення ефективності мультимодальної малоопіоїдної анестезії, як методики анестезіологічного забезпечен- 
ня при проведенні лапароскопічних (ЛПС) оперативних втручань на нирках.

\section{МАТЕРІАЛИ ТА МЕТОДИ}

У дослідження увійшло 10 пацієнтів середнім віком $55 \pm 10,34$ р., яким було виконано ЛПС операції на нирках. Середня маса тіла становила $79 \pm 12,28$ кг. Середня тривалість оперативного втручання - $116 \pm 38,26$ хв., середня тривалість анестезії - 144 $\pm 39,2$ хв.

Всі пацієнти оперувалися в умовах ендотрахеального наркозу. Індукція: в/в пропофол 2 мг/кг, фентаніл 1,52 мкг/кг, атракуріум 0,1 мг/кг. Підтримка анестезії: севофлуран (1,5-2 МАК), кетамін (0,5 мг/кг) та лідокаїн 1 мг/кг болюсно з одночасним налагодженням безперервної в/в інфузії 1,5 мг/кг/год. Середня доза фентанілу, що була використана упродовж всього часу анестезії становила $260 \pm 28,1$ мкг (1,8 мкг/кг/год.). За 30 хв. до закінчення операції в/м вводився нефопам 20 мг. Після закінчення операції хворі отримували в/м ін'єкцію декскетопрофену 50 мг та в/в парацетамол 1000 мг.

\section{РЕЗУЛЬТАТИ}

Під час індукції спостерігалось зниження частоти серцевих скорочень (ЧСС) на $20 \pm 1,8 \%$ щодо вихідних значень. На етапі інтубації трахеї відмічалось збільшення ЧСС щодо попередніх значень на $25 \pm 2,1 \%$. Показники середнього артеріального тиску (АТср) на етапі індукції зменшувалися на $34,3 \pm 3,6 \%$ порівняно $з$ вихідними даними.

Під час підтримки анестезії, після в/в введення субнаркотичних доз кетаміну і вищевказаних доз лідокаїну, ЧСС дорівнювало $67 \pm 4,5$ уд/хв. Показники АТср. були на $11 \pm 2,7 \%$ вищими щодо значень, зареєстрованих на попередньому етапі.

При ЛПС резекціях нирки з пухлиною, на етапі вилучення пухлини додавався фентаніл 50-100 мкг, при цьому реєструвалось збільшення АТср. на $15 \pm 1,4 \%$, та ЧСС на $12 \pm 1,8 \%$ щодо попередніх значень.

Позитивний вербальний контакт був зафіксований в середньому через $13 \pm 1,9$ хв. після закінчення анестезії. Всі хворі були екстубовані в умовах операційної в серед-

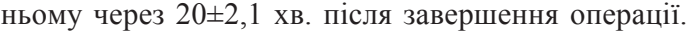

В п/о періоді жоден з пацієнтів не потребував знеболення морфіном. Рівень болю за візуально аналоговою шкалою не перевищував 4 бали.

\section{ВИСНОВоК}

Використання мультимодальної малоопіоїдної анестезії при проведенні ЛПС втручань на нирках має адекватний аналгезуючий ефект, дозволяє відмовитись від використання рутинних доз наркотичних анальгетиків.

\section{СПИСОК ЛІТЕРАТУРИ}

1. Benefit versus Severe Side Effects of Opioid Analgesia: Novel Utility Functions of Probability of Analgesia and Respiratory Depression M. Roozekrans, R. van der Schrier, L. Aarts, [et al] // Anesthesiology.2018.-Vol.128(5).- P. 932-942.

2. Nayak-Rao S. Achieving effective pain relief in patients with chronic kidney disease: $A$ review of analgesics in renal failure. $J$ Nephrol. 2011;24:35-40.

3. Tawfic QA, Bellingham G. Postoperative pain management in patients with chronic kidney disease. J Anaesthesiol Clin Pharmacol. 2015;31(1):6-13. doi:10.4103/0970-9185.150518

Осипенко Д.В., Силанов А.А., Скороходов А.А.

\section{ЛАБОРАТОРНАЯ ОЦЕНКА ЭФФЕКТИВНОСТИ РАЗЛИЧНЫХ СХЕМ ДОЗИРОВАНИЯ ТРАНЕКСАМОВОЙ КИСЛОТЫ У КАРДИОХИРУРГИЧЕСКИХ ПАЦИЕНТОВ}

\section{АКТУАЛЬНОСТЬ ПРОБЛЕМЫ}

Интраоперационое применение транексамовой кислоты (ТК) снижает кровопотерю и частоту трансфузий компонентов крови после операций с искусственным кровообращением (ИК) за счет подавления фибринолиза. Однако дозы ТК представленные в научной литературе значительно различаются между собой и все ещё не определены [1]. Одним из лабораторных методов, используемых для оценки интенсивности фибринолиза, является определение динамики уровня D-димеров [2].

\section{ЦЕЛЬ ИССЛЕДОВАНИЯ}

Провести сравнительную оценку эффективности различных схем дозирования ТК при проведении кардиохирургических операций по их влиянию на динамику уровня D-димеров.

\section{МАТЕРИАЛ И МЕТОДЫ}

В проспективное исследование включено 30 пациентов, которым выполняли операции на сердце через срединный стернотомический доступ в условиях общей анестезии и нормотермического ИК. Сформированы три группы: 1-я группа $(\mathrm{n}=10)$ - во время ИК внутривенно вводили болюс ТК - 10 мг/кг с дальнейшим титрованием 1 мг/кг/час; 2 -я группа $(\mathrm{n}=10)$ - во время ИК внутривенно вводили болюс ТК - 12,5 мг/кг с дальнейшим титрованием 6,5 мг/ кг/час, затем 1 мг/кг/час первые 6 часов после операции; 3 -я группа $(\mathrm{n}=10)$ - контрольная группа.
Значения D-димеров определяли до операции и через 6 часов после, иммунотурбидиметрическим методом коагулометром ACL TOP 500 CTS.

Вычисляли: медиана (Me), первый $(\mathrm{Q} 1)$ и третий квартиль (Q3); для сравнения трех групп использовали критерий Краскела-Уоллиса, двух групп - критерий Манна-Уитни; долей - критерий ч². Различия считались достоверными при $\mathrm{p}<0,05$.

\section{РЕЗУЛЬТАТЫ}

Группы пациентов до операции не различались (табл 1).

Кратность прироста значений D-димеров через 6 часов после операции для 1-й, 2-й и 3-й групп составили соответственно в $1,5(1,1 ; 2,1), 1,6(1,1 ; 2,3)$ и $2,6(1,1 ; 3,5)$ раза, данные различия были статистически значимы $(\mathrm{p}=0,047)$. Рост уровня D-димеров в 1-й и 2-й группах был достоверно меньшим по сравнению с 3-й группой (соответственно $\mathrm{p}=0,042$ и $\mathrm{p}=0,044) ;$ различий между 1 -й и 2-й группами не обнаружено $(\mathrm{p}=0,623)$.

\section{выводы}

Сравнительная оценка двух схем дозирования ТК у кардиохирургических пациентов показала одинаковую эффективность в снижении интенсивности фибринолиза, оцененного по изменению уровня D-димеров. 
Таблица 1. Характеристика групп пациентов.

\begin{tabular}{|c|c|c|c|c|}
\hline Параметр & 1-я группа, n=10 & 2-я группа, n=10 & 3-я группа, n=10 & $\mathrm{p}$ \\
\hline Возраст, лет & $65(59 ; 68)$ & $62(58 ; 68)$ & $62(55 ; 68)$ & 0,794 \\
\hline Масса, кг & $80(76 ; 84)$ & $76(73 ; 90)$ & $78(70 ; 89)$ & 0,906 \\
\hline Рост, см & $169(164 ; 176)$ & $169(158 ; 170)$ & $167(164 ; 170)$ & 0,756 \\
\hline Соотношение по полу (муж/жен) & $6 / 4$ & $4 / 6$ & $5 / 5$ & 0,670 \\
\hline Тип операции (реваскуляризация / протезирование клапанов) & $5 / 5$ & $6 / 4$ & $4 / 6$ & 0,670 \\
\hline Длительность операции, мин. & $300(260 ; 350)$ & $270(250 ; 320)$ & $270(255 ; 315)$ & 0,740 \\
\hline Длительность ИК, мин & $105(87 ; 125)$ & $91(61 ; 102)$ & $86(71 ; 103)$ & 0,169 \\
\hline D-димеры до операции, нг/мл & $153(115 ; 195)$ & $147(123 ; 276)$ & $184(140 ; 309)$ & 0,301 \\
\hline
\end{tabular}

\section{СПИСОК ЛИТЕРАТУРЫ}

1. Анестезия Рональда Миллера В 4-х томах / Под ред. Р. Миллера; Пер. с англ.; Под общ. ред. К.М. Лебединского. - СПб.: Человек. $-2015 .-1666$
2. Greilich P.E. Antibrinolytic therapy during cardiopulmonary bypass reduces proinammatory cytokine levels: A randomized, double-blind, placebo-controlled study of aminocaproic acid and aprotinin $P . E$. Greilich C. F Brouse, C.W. Whitten [et al.] /I J Thorac Cardiovasc Surg.-2003-126/-P.1498-1503

\section{УДК: $616.381-002-053.2-089.5-07-092$ \\ Перова-Шаронова В.M. \\ ІНТРААБДОМІНАЛЬНИЙ ТИСК, РІДИННИЙ БАЛАНС ТА ТОВЩИНА КИШКОВОЇ СТІНКИ У ДІТЕЙ 3 АПЕНДИКУЛЯРНИМ ПЕРИТОНІТОМ ПРИ РІЗНИХ МЕТОДАХ ПІСЛЯОПЕРАЦІЙНОГО ЗНЕБОЛЮВАННЯ}

КЗ ЛОР ЛОДКЛ «ОХМАТДИТ», ЛЬвів, Україна

\section{АКТУАЛЬНІСТЬ}

Ускладнені інтраабдомінальні інфекції є ризиком розвитку сепсису, синдрому поліорганної неспроможності та інтраабдомінальної гіпертензії (ІАГ). Одним 3 патофізіологічних механізмів розвитку ІАГ у важко хворих $€$ набряк кишечної стінки (КС), який може розвинутись внаслідок об'ємної інфузійної терапії, позитивного рідинного балансу та синдрому «капілярної втрати». Підвищений інтраабдомінальний тиск (IAT) призводить до порушення спланхнічного кровоплину та лімфатичного відтоку та ще більшого набряку КС. Пацієнтам з ІАГ показана ефективна післяопераційна (ПО) аналгезія. Оптимальної аналгетичної методики для даної групи пацієнтів не описано.

\section{META}

Дослідити залежність між методами ПО знеболювання, IAT, рідинним балансом та товщиною КС у дітей $з$ апендикулярним перитонітом.

\section{МАТЕРІАЛИ ТА МЕТОДИ}

Обстежено 72 дитини після оперативних втручань 3 приводу апендикулярного перитоніту. Дітей рандомізовано на 3 групи в залежності від методу ПО знеболення: група «Опіоїди» (внутрішньовенна інфузія морфіну, $\mathrm{n}=25$ ), група «Лідокаїн» (внутрішньовенна інфузія лідокаїну, $\mathrm{n}=22$ ), група «ЕА» (епідуральна анестезія, $\mathrm{n}=26$ ). Групи не відрізнялись за антропометричними показниками, віком, статтю, діагнозом та методом оперативного втручання. В ПО періоді дітям вимірювались IAT (непрямим методом), товщина КС (за допомогою УзД) та обчислювався рідинний баланс. В залежності від рівня IAT дітей поділено на підгрупи: «Без ІАГ» та «ІАГ».

\section{РЕЗУЛЬТАТИ ТА ОБГОВОРЕННЯ}

У дітей з ІАГ спостерігались більш позитивний рідинний баланс та більша товщина КС ніж у дітей без IАГ. (Табл. 1). Це, можливо, обумовлено важкістю стану пацієнтів 3 IАГ та пов'язаною 3 цим потребою у додат- ковій інфузії, а також порушенням спланхнічного кровоплину та лімфатичного відтоку внаслідок ІАГ, що призводило до набряку КС. При аналізі по підгрупам товщина КС була більшою в групі «Опіоїди» порівняно з групами «Лідокаїн» та «ЕА» у дітей з ІАГ (Табл. 2). Це може бути обумовлено менш позитивним рідинним балансом при знеболенні лідокаїном та властивостями ЕА покращувати мезентеріальний кровоплин. Окрім того внутрішньовенна інфузія лідокаїну та ЕА стимулюють відновлення перистальтики, що покращує лімфатичний відтік, в той час як опіоїди пригнічують моторну функцію ШКТ. Також описані протизапальні властивості лідокаїну при внутрішньовенній інфузії, що призводить до зниження вивільнення про- і протизапальних цитокінів та може запобігати набряку КС.

Таблиця 1. Середні показники у пацієнтів з IAГ та без IAГ.

\begin{tabular}{|c|c|c|}
\hline Показник/Група & $\begin{array}{c}\text { Без ІАГ } \\
n=35\end{array}$ & $\begin{array}{c}\mathrm{IA \Gamma} \\
\mathrm{n}=38\end{array}$ \\
\hline 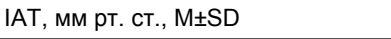 & $7,53 \pm 1,62$ & $12,51 \pm 2,15^{\star}$ \\
\hline 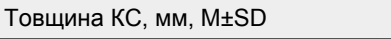 & $2,15 \pm 0,83$ & $2,90 \pm 0,79^{*}$ \\
\hline Рідинний баланс, мл, Ме (Q1; Q3) & $\begin{array}{c}400 \\
(12,5 ; 717)\end{array}$ & $\begin{array}{c}815^{\star} \\
(391,25 ; 1410)\end{array}$ \\
\hline
\end{tabular}

$* \mathrm{p}<0,05$

Висновки. ПО знеболення шляхом в/в інфузії лідокаїну та епідуральної аналгезії дозволяє запобігти набряку кишкової стінки. Рідинний баланс був найбільш оптимальним на тлі післяопераційного знеболення лідокаїном.

\section{СПИСОК ЛІТЕРАТУРИ}

1. Cordemans C, De Laet I, Van Regenmortel N, Schoonheydt K, Dits H, Huber W, Malbrain ML. Fluid management in critically ill patients: the role of extravascular lung water, abdominal hypertension. 
Таблиця 2. Середні показники у пацієнтів по підгрупам знеболювання.

\begin{tabular}{|c|c|c|c|c|c|c|}
\hline \multirow[b]{2}{*}{ Показник/Група } & \multicolumn{2}{|c|}{ Опіоїди } & \multicolumn{2}{|c|}{ Лідокаїн } & \multicolumn{2}{|c|}{ EA } \\
\hline & $\begin{array}{c}\text { Без ІАГ } \\
n=7\end{array}$ & $\begin{array}{l}\text { IAГ } \\
n=18\end{array}$ & $\begin{array}{c}\text { Без ІАГ } \\
n=12\end{array}$ & $\underset{n=10}{\mathrm{IA \Gamma}}$ & $\begin{array}{c}\text { Без ІАГ } \\
n=16\end{array}$ & $\begin{array}{l}\mathrm{IA \Gamma} \\
\mathrm{n}=10\end{array}$ \\
\hline IAT, мм рт. ст., M $\pm S D$ & $7,96 \pm 1,86$ & $12,69 \pm 2,15^{*}$ & $7,16 \pm 1,68$ & $11,56 \pm 2,37^{*}$ & $7,55 \pm 1,5$ & $11,65 \pm 2,16^{*}$ \\
\hline 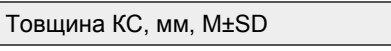 & $2,26 \pm 0,76$ & $3,27 \pm 0,88^{*}$ & $2 \pm 0,58$ & $2,61 \pm 0,64^{*}$ & $2,19 \pm 0,95$ & $2,82 \pm 0,71^{*}$ \\
\hline Рідинний баланс, мл, Мe (Q1; Q3) & $\begin{array}{c}480 \\
(160 ; 940)\end{array}$ & $\begin{array}{c}1030^{*} \\
(549,5 ; 1410)\end{array}$ & $\begin{array}{c}280 \\
(147,5 ; 590)\end{array}$ & $\begin{array}{c}520^{*} \\
(0 ; 950)\end{array}$ & $\begin{array}{c}420 \\
(0 ; 717)\end{array}$ & $\begin{array}{c}705^{\star} \\
(425 ; 1657,5)\end{array}$ \\
\hline
\end{tabular}

$* \mathrm{p}<0,05$

capillary leak, and fluid balance. Ann Intensive Care. 2012;2(Suppl 1): S1.

2. Guay J, Nishimori M, Kopp SL. Epidural Local Anesthetics Versus Opioid-Based Analgesic Regimens for Postoperative Gastrointestinal Paralysis, Vomiting, and Pain After Abdominal Surgery: A Cochrane Review. Anesth Analg. 2016;123(6):1591-1602.

3. Lauder GR (2017) A Review of Intravenous Lidocaine Infusion Therapy for Paediatric Acute and Chronic Pain Management. In
Maldonado $C$ (ed) Pain relief. From analgesics to alternative therapies. InTech. Chapter 9. https://doi.org/10.5772/66771

4. Leppdniemi A, Kimball EJ, De Laet I, Malbrain ML, Balogh ZJ, De Waele JJ. Management of abdominal sepsis-a paradigm shift? Anaesthesiol Intensive Ther. 2015;47(4):400-8.

5. Reintam Blaser A, Malbrain MLNG, Regli A. Abdominal pressure and gastrointestinal function: an inseparable couple? Anaesthesiol Intensive Ther. 2017:49(2):146-158.

УДК: 617-001-031.14-083.98

Підгірний Я.М., Матолінець Н.В., Іванюшко О.В., Ільчишин О.Я.

\section{МЕТОД ОПТИМІЗАЦІї ГЕМОДИНАМІЧНОГО СТАТУСУ У ПАЦІЕНТІВ В ГОСТРОМУ ПЕРІОДІ ПОЛІТРАВМИ}

Львівський національний медичний університет імені Данила Галицького

\section{АКТУАЛЬНІСТЬ}

При політравмі у 80\% постраждалих пацієнтів смерть настає у перші 6 годин від некомпенсованого шоку [1]. Вирішення питання кількості інфузійної терапії, яка необхідна для забезпечення адекватної перфузії органів і систем у критичного хворого до цього часу є вкрай актуальним. Золотим стандартом вирішення даного питання $є$ вимірювання серцевого викиду (CB) за допомогою методу термодилюції з використанням катетера Сван-Ганца [5]. Проте, враховуючи інвазивність даної технології, вона не знайшла широкого застосування не тільки в клініці анестезіології та інтенсивної терапії загального профілю, але й в клініці анестезіології та інтенсивної терапії кардіохірургічного профілю. Тому, до цього часу іде пошук неінвазивних технологій, які б дозволяли моніторувати показники центральної гемодинаміки та реакцію на волемічне навантаження. Однією з перспективних технологій, яка дає можливість моніторувати реакцію серцево-судинної системи на волемічне навантаження у критичного хворого $\epsilon$ технологія esCCO (Estimated Continuous Cardiac Output). Вона дає можливість неінвазивно розрахунково безперервно (пролонговано) вимірювати серцевий викид в on-line режимі і може забезпечувати покращений моніторинг гемодинамічного статусу пацієнта та подальшу тактику лікування і ранньої ресусцитації $[2,3,4]$. За даними літератури показники еsCCO, отримані на основі часу передачі пульсової хвилі (РWTT), корелюють з СВ, виміряним за допомогою методу термодилюції з використанням катетера Сван-Ганца [5].

\section{МЕТА ДОСЛІДЖЕННЯ}

Оцінити можливості технології еsCCO та доцільності його застосування у пацієнтів в гострому періоді політравми.

\section{МАТЕРІАЛИ I МЕТОДИ}

У дослідженні брало участь 40 пацієнтів, які лікувались 3 приводу політравми у відділенні анестезіології та інтенсивної терапії (ВАIT) КНП «КЛШМД м. Львова». Середній вік - 48,4t5,2 роки. Термін госпіталізації в се- редньому - 30 хвилин. На дошпитальному етапі хворим проводилась транспортна іммобілізація, введення знеболювальних препаратів, інфузійна терапія (ІфT).

В основній (1) групі (n=20) крім загально доступних показників гемодинаміки (АТ, ЧСС, сатурації крові) моніторували показники центральної гемодинаміки за допомогою модуля еsCCO, інтегрованого в монітор Life Scope (Nihon Kohden, Японія) для оцінки сприйнятливості до інфузійної терапії та необхідності волемічної і інотропної підтримки у пацієнтів в гострому періоді політравми. У контрольній (2) групі $(\mathrm{n}=20)$ для порівняльного аналізу реєстрували тільки традиційні показники - АТ, ЕКГ, сатурацію крові $\left(\mathrm{SpO}_{2}\right)$ за допомогою багатофункціональних моніторів Philips IntelliVue (MP20).

\section{РЕЗУЛЬТАТИ}

При поступленні у постраждалих обох груп середній рівень АТ та ЧСС достовірно не відрізнялись: АТсист (1гр.) - 86,5 $\pm 2,5$ мм рт. ст., АТсист ( 2 гр.) - 85,5 $\pm 2,5$ мм рт. ст.; АТдіаст (1гр.) - 46,0 $\pm 1,7$ мм рт. ст., АТдіаст ( 2 гр.) - 48,5 $\pm 1,5$ мм рт. ст., ЧСС ( 1 гр. ) - $129 \pm 8$ уд/ хв, ЧСС (2 гр.) - $122 \pm 5$ уд/хв. СВ у хворих першої групи при поступленні в стаціонар становив $3,2 \pm 0,5$ л/хв На тлі проведеної інтенсивної терапії впродовж першої доби в пацієнтів обох груп стабілізувались показники АТ та ЧСС (у хворих першої групи АТсист 122,9 $\pm 6,2$ мм рт. ст., АТдіаст 69,7 $\pm 2,3$ мм рт. ст. ЧСС $88 \pm 8$ уд/хв, у хворих другої групи АТсист 112,2 \pm 5,9 мм рт. ст., АТдіаст $67,5 \pm 2,1$ мм рт. ст., ЧСС $92 \pm 4$ уд/хв.) У хворих першої групи наприкінці першої доби інтенсивної терапії СВ становив 5,5 $\pm 0,3$ л/хв. Дози інотропних препаратів у хворих обох груп були співставимими. Якісний склад інфузійної терапії у хворих обидвох груп також був однаковим. Слід зауважити, що стабілізацію гемодинаміки у хворих першої групи було досягнено за рахунок зменшення об'єму інфузійної терапії на 13,5\% в порівнянні з пацієнтами контрольної групи. 


\section{вИСновки}

У пацієнтів в гострому періоді політравми застосування неінвазивного моніторингу центральної гемодинаміки за допомогою модуля еsСCO є простим та інфор-мативним методом для виявлення швидких змін серцевого викиду та ефективної корекції гемодинамічного статусу; дає більш повну та достовірну інформацію, аніж традиційні показники.

\section{КЛЮчОВІ СЛОВА}

Політравма, серцевий викид, гемодинаміка.

\section{СПИСОК ЛІТЕРАТУРИ}

1. Устінов О.В. Травматизм - головна причина смерті серед молодi та людей віком до 40 років? [Електронний ресурс] 2017.

https://www.umj.com.ua/article prichina-smerti-sered-molodi-ta-lyudej-vikom-do-40-rokiv Demetrios Sirounis Assessment of adequacy of volume resuscitation J.H. Boyd // Current Opinion in Critical Care: Post Author Corrections. - July 29, 2016.

3. Multicenter study verifying a method of noninvasive continuous cardiac output measurement using pulse wave transit time: a comparison with intermittent bolus thermodilution cardiac output Yamada T., Tsutsui M., Sugo Y., Sato T., Akazawa T., Sato N., Yamashita K., Ishihara H., Takeda J. // Anesthesia and analgesia. 2012. - 115(1). - P.82-7.

DOI: $10.1213 / A N E .0 b 013 e 31824 e 2 b 6 c$

4. Comparison of esCCO and transthoracic echocardiography for noninvasive measurement of cardiac output intensive care / Bataille $B$. M. Bertuit, M. Mora [et al.] // Br. J. Anaesth. 2012 - No 109(6). M. Bertuit,

5. Vincent J L. Clinical review: Update on hemodynamic monitoring a consensus of 16/ J.L.Vincent, A Rhodes, A. Perel, G.S. Martin Cet

УДК: $616-089.5-031.81 / 037$

Полінчук І.С., Малахов П.С., Полінчук І.М., Сидорко Ю.В., Арбузова В.О., Туряниця С.В., Цимбал Ю.Ф., Степаненко П.П.

\section{ПСИХОФІЗІОЛОГІЧНІ В ЕЛЕКТРОФІЗІОЛОГІЧНІ КРИТЕРІЇ БЕЗПЕКИ ЗАГАЛЬНОЇ AHECTE3IÏ}

Херсонська міська клінічна лікарня ім. Є.Є. Карабелеша

\section{АТУАЛЬНІСТЬ ПРОБЛЕМИ}

Анестезіологічна безпека - поняття багатогранне. Препарати для загальної анестезії негативно впливають на вищі психічні функції, викликають післяопераційну когнітивну дисфункцію (ПОКД). Залишається відкритим питання про “ідеальний” анестетик з позиції ПОКД.

\section{META РОБОТИ}

Підвищення анестезіологічної безпеки шляхом вибору найбільш оптимальних схем загальної анестезії в контексті відновлення психофізіологічних функцій (ПФФ) та біоелектричної активності головного мозку у післяопераційному періоді. Для досягнення цієї мети поставлені завдання: а) вивчити швидкість відновлення ПФФ пацієнтів при різних схемах загальної анестезії з використанням пропофолу, тіопенталу натрію, кетаміну, а також низькопотокової (low-flow) інгаляційної анестезії севофлураном; б) дослідити рівень біоелектричної активності головного мозку в періопераційному періоді методом електроенцефалографії (ЕЕГ) при різних схемах загальної анестезії.

\section{МАТЕРІАЛИ ТА МЕТОДИ}

Дослідження виконане на базі ВАІТ «ХМКЛ ім. С.С. Карабелеша». Вивчено вплив різних схем загальної анестезії з використанням пропофолу - гр. I $(\mathrm{n}=22)$, тіопенталу натрію - гр. II $(\mathrm{n}=22)$, кетаміну - гр. III $(\mathrm{n}=23)$, низькопотокової (low-flow) інгаляційної анестезії севофлураном - гр. IV $(\mathrm{n}=37)$ на швидкість відновлення ПФФ у післяопераційному періоді. За віком та ін. критеріями досліджувані групи пацієнтів були однорідними ( $p>0,40$ при усіх порівняннях за результатами дисперсійного аналізу ANOVA і критерію с2). Рівень ПФФ вивчався за допомогою психометричного тесту “Виключення зайвого”, рівень біоелектричної активності головного мозку методом ЕЕГ (система DX-3000). Статобробка матеріалів досліджень проводилась за допомогою ліцензійного пакету програм STATISTICA v.6.1.

\section{РЕЗУЛЬТАТИ ТА ОБГОВОРЕННЯ}

Результати дослідження ПФФ за тестом «Виключення зайвого», умови якого передбачають виконання завдань на $100 \%$ (10 із 10 можливих), виявились наступними. Найшвидше відновлення ПФФ у післяопераційному періоді відбувалось у гр. IV (севофлуран), далі - в гр. I (пропофол), потім - в гр. II (тіопентал натрію), а найповільніше - в гр. III (кетамін). Результати досліджень біоелектричної активності головного мозку в періопераційному періоді методом ЕЕГ показали, що найшвидше відновлення цього показника відбувалось при проведенні загальної анестезії з використанням низькопотокової (lowflow) інгаляційної анестезії севофлураном, а далі, відповідно, розмістились гр. I, гр. II і гр. III.

\section{вИсновки}

1. Рівень ПФФ та біоелектрична активність мозку у післяопераційному періоді найшвидше відновлювалась при використання низькопотокової інгаляційної анестезії севофлураном.

2. Вказану методику можна вважати «золотим» стандартом безпеки пацієнта при виконанні планових оперативних втручань.

\section{СПИСОК ЛІТЕРАТУРИ}

1. Steinmerz J. Long-term consequences of postoperative cognitive dysfunction / J. Steinmerz, K. B. Christensen, T. Lund [et al.] Anaesthesiology - 2009 - Vol 110 No 3 - P 548-555.

2. Rasmussen L.S. Postoperative cognitive dysfunction: incidence and prevention I. S Rasmussen // Best Practice \& Research Clinical Anesthesiology. - 2006. - Vol. 20, № 2. - P. 315-330. 


\title{
Правдіна Н.С.
}

\section{РЕСПІРАТОРНА ПІДТРИМКА В ІНТЕНСИВНІЙ ТЕРАПІЇ ПАЦІЄНТІВ 3 ДИХАЛЬНОЮ НЕДОСТАТНІСТЮ}

Українська військово-медична академія, м. Київ, Україна.

Неінвазивна штучна вентиляція легень (НIB) один із ефективних новітніх методів корекції гострої дихальної недостатності, який у певних випадках може бути альтернативою традиційній штучній вентиляції легень (ШВЛ). НІВ характеризується меншою частотою ускладнень і має низку переваг перед традиційною ШВЛ (Susan R.,Wilcox, 2019).

На даний час відсутні загальні дані про епідеміологічну картину гострої дихальної недостатності. Існують показники по окремих нозологічних формах:

- 16-18 \% пацієнтам з ГРДС показана подовжена киснева підтримка методом штучної вентиляції легень (ШВЛ);

- 3-10 \% від загальної кількості пневмоній складають випадки, які потребують госпіталізації до відділення інтенсивної терапії з ознаками ГДН.

\section{META РОБОТИ}

Покращити якість надання медичної допомоги пораненим та хворим з дихальною недостатністю, уникнути ускладнень пов'язаних з інтубацією трахеї.

Дослідження проводились на базі Національного військово-медичного клінічного центру. В дослідженні приймає участь 40 осіб (20 осіб дослідна група, 20 - контрольна, яким проводилася інсуфляція зволоженого кисню через носові канюлі зі швидкістю 6-8 літрів за хвилину) ознаками дихальної недостатності. Пацієнтів поділено на 3 групи, залежно від ступеню дихальної недостатності - легкого, середнього та важкого ступеню - 6 осіб (30\%), 8 осіб (40\%) і 6 осіб (30\%) відповідно. Для усунення ознак дихальної недостатності у першої групи пацієнтів достатньо було інсуфляції зволоженого кисню через носові канюлі або лицеву маску, за швидкістю $6-12$ літрів за годину. У інтенсивній терапії пацієнтів другої та третьої групи інсуфляція зволоженого кисню була не ефективною, у зв'язку з цим їм застосовували неінвазивну вентиляцію легень через щільну лицеву маску, апаратом «UVENT» в режимі CPAP, з РЕEP $4-8$ см. водного стовпчика. У 4 пацієнтів (20\%) через 2 години після початку проведення $\mathrm{HIB}$ показники $\mathrm{SpO}_{2}$ не перевищували 85$90 \%$, наростали клінічні прояви дихальної недостатності, у зв'язку з цим було прийнято рішення про переведення пацієнтів на ШВЛ через ендотрахеальну інтубаційну трубку. У 10 пацієнтів (50\%) відмічається позитивний ефект від застосування НIB, про що свідчили клінічний стан хворих та нормалізація показника $\mathrm{SpO}_{2}$.

\section{висновок}

Як свідчить наш клінічний досвід і результати клінічних та інструментальних досліджень, у військових з різноманітним ступенем поранення, у яких виникла дихальна недостатність, застосування неінвазивної вентиляції легень на ранніх стадіях виникнення дихальної недостатності дає можливість уникнути ускладнень, пов'язаних з інтубацією трахеї та сприяти покращенню результатів лікування.

Рожко В. И., Слинченков В.В.,

УДК 616.37-002:615.874

\section{МЕСТО НУТРИТИВНОЙ ПОДДЕРЖКИ ПРИ ЛЕЧЕНИИ ОСТРОГО БИЛИАРНОГО ПАНКРЕАТИТА, РАЗВИВШЕГОСЯ В ПОСТОПЕРАЦИОННЫЙ ПЕРИОД ПОСЛЕ ЛАПАРОСКОПИЧЕСКИХ ОПЕРАЦИЙ НА ЖЕЛЧЕВЫВОДЯЩИХ ПУТЯХ}

\author{
КЗ «Дніпровська міська клінічна лікарня № 11» ДМР.
}

Дніпровський міський центр ендоскопічної хірургії. Відділення анестезіології та інтенсивної терапії.

В общей структуре заболеваемости панкреатитом на долю билиарного панкреатита развившегося после операций на желчевыводящих путях приходится 9,1\%.При этом летальность при нераспознанном и не леченном билиарном панкреатите, по данным разных авторов, остается на уровне $25-75 \%$. В раннем периоде заболевания переход от легкой формы к тяжелой может произойти очень быстро. Поэтому очень важно провести своевременную диагностику и начать адекватную терапию до развития тяжелой полиорганной недостаточности.

\section{ЦЕЛЬ РАБОТЬ}

Изучить влияние раннего смешанного питания на течение острого билиарного панкреатита развившегося после лапароскопических операций на желчевыводящих путях

\section{МАТЕРИАЛЫ И МЕТОДЫ}

Проведен ретроспективный анализ результатов обследования и лечения 11 пациентов, у которых в ранний послеоперационный период, развился острый билиарный панкреатит. Больные разделены на 2 группы. 1 группа

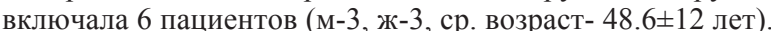
2 группа включала 5 пациентов (м-3, ж-2, ср. возраст$52 \pm 11$ лет). Всем пациентам проводилась стандартная те-

рапия согласно протокола. Больным 1 группы через 4 часа после проведения обьемной инфузионной терапии начинали круглосуточное парентеральное питание. С этой целью использовали оликлиномель, который вводили внутривенно в дозе 750 мл круглосуточно. К концу первых суток к парентеральному питанию, дополнительно, через установленный назогастральный зонд начинали вводить питательную смесь Nutricomp со скоростью 20 мл/час, круглосуточно. Больным 2 группы на 2-3 сутки начинали парентеральное питание, используя кабивен в дозе 1000 мл в течение суток. Проведен анализ показателей гемодинамики (АДср, ЧСС, СИ, ОПСС) и биохимических показателей (глюкоза крови, амилаза крови, АЛТ, АСТ, ЩФ, общий белок крови) на 1,3 и 5 сутки течения болезни.

\section{РЕЗУЛЬТАТЫ И ОБСУЖДЕНИЕ}

Биохимические показатели пациентов обеих групп при поступлении в ОАРИТ характеризовались резким повышением исследуемых показателей на фоне снижения обще- 
го белка. В тоже время к 5 суткам проведенного лечения амилаза крови у пациентов 1 группы практически достигла нормы, в то время как амилаза крови пациентов 2 группы осталась выше нормы на $50.4 \%$. Снижение АЛТ и АCT у больных обеих групп не достигло нормальных значений, но у пациентов, получивших раннюю нутритивную поддержу путем смешанного питания, эти показатели значительно больше приблизились к нормальным показателям, чем у пациентов 2 группы. Такая же динамика наблюдалась и в изменении общего белка крови. Показатели гемодинамики у пациентов обеих групп существенно друг от друга не отличались. Глюкоза крови у пациентов обеих групп в течение всего времени наблюдения держалась на уровне 5-7ммоль/л. Средний койко-день пребывания в ОАРИТ пациентов 1 группы составил 5.1 к/д, пациентов 2 группы 7.2 к/д. Срок пребывания в хирургическом стационаре больных 1 группы (14,8 к/д), в сравнении со сроком нахождения в стационаре пациентов 2 группы (19.4 к/д) уменьшился на $31,08 \%$. Осложнений, связанных с проведением нутритивной поддержки в обеих группах не было. Летальности не было.

\section{ВЫвод}

Раннее смешанное питание современными питательными смесями для парентерального питания (оликлиномель) и энтерального питания (нутрикомп), на фоне базовой интенсивной терапии позволяет при билиарном панкреатите предупредить развитие тяжелой полиорганной недостаточности, снизить потери белка, уменьшить срок пребывания пациента в стационаре.

\section{СПИСОК ЛИТЕРАТУРЬ}

1. Зварічук O. А., Говенко А. В. Сучасна тактика нутритивно підтримки при гострому панкреатиті//Медицина неотложны состояний.-2019.- №2 (97).С 30-38.

2. Теоретические предпосылки и практические основы нутриционной поддержки в клинике критических состояний: [Моногр.] / Подоб

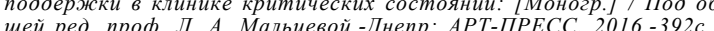

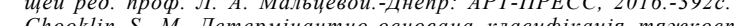
. Chooklin S. М. Детермінантно-основана класифікаиія тяжкості сострого панкреатиту: Мімнародній мультидисииллінарний mark et al. //Шnumarbua xipypгis. - 2015. № 1 - c. 10-18.

\section{Руденко В.Л., Тарасенко С.О., Товкай О.А., Єфрімова О.О.}

\section{МУЛЬТИМОДАЛЬНА АНАЛГЕЗІЯ ПРИ ОПЕРАТИВНИХ ВТРУЧАННЯХ НА ПРИЩИТОПОДІБНИХ ЗАЛОЗАХ ПРИ ПЕРВИННОМУ ГІПЕРПАРАТИРЕОЗІ}

Український науково-практичний центр ендокринної хірургії, трансплантації ендокринних органів і тканин

\section{Вступ}

Виникнення больового синдрому різної інтенсивності є невід'ємною складовою та наслідком переважної більшості оперативних втручань. За даними реєстру, проведеного у США, більше $80 \%$ пацієнтів відчувають гострий біль в післяопераційному періоді, $75 \% 3$ яких розцінюють його інтенсивність від помірно вираженого до нестерпного. Встановлено, що однією з основних причин, що перешкоджають ранній активізації пацієнтів, більш швидкому та повноцінному функціональному відновленню після оперативного втручання $є$ недостатнє післяопераційне знеболення. Поряд з усуненням фізичного страждання пацієнтів, що зумовлене больовими відчуттями, метою застосування мультимодального підходу до знеболення $є$ створення психологічного комфорту та покращення якості життя пацієнтів, що прискорює функціональну реабілітацію в післяопераційному періоді, зменшує терміни госпіталізації, частоту ускладнень та одночасно $є$ засобом профілактики формування хронічного больового синдрому. Анальгезія без опіоїдів або суттєве зменшення їх застосування - один із ключових факторів швидкого відновлення після операції згідно ERAS протоколу.

\section{META РОБОТИ}

Оцінити ефективність мультимодальної аналгезії при паратиреоїдектоміях у пацієнтів з первинним гіперпаратиpеозом.

\section{МАТЕРІАЛИ ТА МЕТОДИ}

118 пацієнтів було включено в дослідження. Оперативні втручання виконували на тлі загальної анестезії з ШВЛ у вигляді низько/мінімально потокової інгаляційної анестезії (ІНПА/ІМПА) севофлураном 3 інтубацією трахеї або тотальною внутрішньовенною анестезією (ТВВА) пропофолом з використанням ларингеальної маски. Всім пацієнтам за 30-40 хвилин до початку операції проводилаcя pre-emptive аналгезія (в/в введення декскетопрофену 50 мг, парацетамолу - 1000 мг, дексаметазону - 4 мг), застосовували ондасетрон - 4-8 мг в/в. Пацієнтам I і III груп виконувалась білатеральна блокада поверхневого шийного сплетення (ББПШС) $0,5 \%$ розчином бупівакаїну (Лонгокаїн) 75-100 мг з додаванням 4 мг дексаметазону в якості ад'юванта. Залежно від способу ведення анестезії пацієнти були розділені на три групи. Пацієнтам I групи “ББПШС-севофлуран" (ББПШС С) n=25 (21,2\%) та II групи “севофлуран” (Без_ББПШС_С) n=77 (65,2\%), проводилася загальна анестезія, інтубація трахеї з введенням міорелаксатів та базовою анестезією у вигляді IНПА/ IMПА севофлураном при FGF 700-400 мл/хв 3 підтримкої end-tidal anaesthetic concentration (ETAC) на рівні 1,3$1,5 \%$ (H”1,9-2,0 MACawake). Аналгетичний компонент забезпечувався дробним введенням фентанілу $0,005 \%$ по 50-100 мкг кожні 15-30 хвилин

Пацієнтам III групи”ББПШС пропофол-ларингеальна маска" (ББПШС_П-ЛМ) n=16 (13,6\%) проводилась поєднана анестезія з використанням ларингеальної маски, без введення міорелаксантів, FGF $=2000$ мл/хв. з FiO2 - 0.5\%. Підтримку анестезії проводили за допомогою безперервної інфузії $1 \%$ розчину пропофолу з додаванням $2 \%$ розчину лідокаїну $80-120$ мг на кожні 500 мг розчину зі швидкістю 10-4 мл/кг/год за схемою «stepdown regime», аналгетичний компонент забезпечувався інфузією фентанілу $0,005 \%$ по $1-2$ мкг/кг/год.

В післяопераційному періоді використовувалось знеболення за принципом preventive analgesia: внутрішньовенно вводився декскетопрофен кожні 8 годин протягом 2 діб. Парацетамол в дозуванні 1000 мг вводилися внутрішньовенно перші 6 годин післяопераційно з подальшим переходом на пероральне застосування по 500-1000 мг кожні 6-8 годин.

Оцінка рівня післяопераційного болю проводилась за 100 мм шкалою ВАШ. Частота виникнення післяопераційної нудоти і блювання (ПОНБ) оцінювалась за шкалою, де 0 = відсутні нудота i/aбо блювання, 1 = нудота, 2 = позиви до блювання, 3 = блювання. Важка ПОНБ оцінювалась як сумарна частота показників 2 і 3. Статистична 
обробка даних проводилась із застосуванням пакета прикладних програм Statistica 10.0 (StatSoft) з використанням параметричних і непараметричних методів.

\section{РЕЗУЛЬТАТИ}

За віковими та антропометричними показниками пацієнти всіх груп були однорідні. Вік хворих складав (M \pm y) $57,3 \pm 12,4 ; 55,1 \pm 12,9$ та $57,8 \pm 5,01$ років. IMT (M \pm y) складав $29,7 \pm 4,81 ; 27,8 \pm 5,29$ та $30,0 \pm 3,57$ кг/м² відповідно в групах ББПШС С, Без ББПШС С та ББПШС П-ЛМ. Інтраопераційне споживаня фентанілу склало $261,5 \pm 87,6$ мкг, 334,1 $\pm 73,1$ мкг, 209,0 \pm 44,7 мкг відповідно в групах ББПШС_С, Без_ББПШС_С та ББПШС_П-ЛМ $з$ достовірною різницею між групами за критерієм Уілкоксона $(\mathrm{p}<0,01)$. Таким чином, нами прослідковано, що поєднана анестезія із виконанням ББПШС сприяє достовірно меншому споживанню фентанілу. Також достовірно менша доза фентанілу була використана в групі ББПШС П-ЛМ, де не проводилась інтубація трахеї. Рівень болю за ВАШ через 3 години після операції був нижчим у групах поєднаної анестезії - ББПШС_С та ББПШС_П-ЛМ - і складав відповідно $23,2 \pm 3,4$ мм і $22,42 \pm 3,7$ мм (p=0,873), мав достовірну різницю 3 групою Без ББПШС С, де ВАШ був 43,2 $\pm 3,6$ мм. Така достовірна різниця спостерігалася протягом перших 12 годин післяоперційного періоду.
Жодних проявів ПОНБ не було у $87 \%$ хворих групи ББПШС_П_ЛМ, у $77 \%$ гурпи ББШПС_С та тільки у 61 \% хворих в групі БЕ3_ББПШС_С. Важка ПОНБ відмічена відповідно у $6 \%, 12 \%$ та $20 \%$ пацієнтів (різниця між групами достовірна для обох показників, $\mathrm{p}<0,05$, критерій $\mathrm{ч}^{2}$ Пірсона).

\section{висновки}

Застосування мультимодальної аналгезії з імплетентацією рекомендацій протоколу ERAS в паратиреоїдній хірургії достовірно зменшує споживання інтраопераційно опіоїдів, знижує частому ПОНБ. Виконання регіональної анестезії (ББПСШ з додаванням дексаметазону) забезпечує менший рівень болю в післяопераційному періоді.

\section{СПИСОК ЛІТЕРАТУРИ}

1. Бабенко В.В. Післяопераційний біль: можливості медикаментозної корекції. / В.В Бабенко., О.А. Спанчінщева, В.О. Ярош В.О. // Біль, знеболення та інтенсивна терапія. - 2019. - №2 - С. 31-36 DOI: https://doi.org/10.25284/2519-2078.2(87).2019.171005

2. Pedziwiatr M. Early implementation of Enhanced Recovery after Surgery (ERAS®) protocol - Compliance improves outcomes: A prospective cohort study. [text] / M. Pedziwiatr, M. Kisialeuski, M. Wierdak, M. Stanek, M. Natkaniec, M. Matlok, P. Major, A. Budzynski. // International Journal of Surgery. - 2015. -№ 21.- C. 75-81.

3. Руденко В.Л. Анестезіологічне забезпечення під час оперативного втручання при первинному гіперпаратиреозі.[текст] / В.Л. Руденко, М.В. Кунатовський, С.О. Тарасенко // Клінічна ендокриноDOI: https://doi.org/10.24026/1818-1384.4(64).2018.150224

\section{Семененко C.I., Семененко А.I.}

\section{ЦЕРЕБРОПРОТЕКТОРНІ ДОЗИ АДЕМОЛУ В УМОВАХ ЧМТ У ЩУРІВ}

\section{АКТУАЛЬНІСТЬ ПРОБЛЕМИ}

На сьогодні основною складовою інтенсивної терапії при черепно-мозковій травмі (ЧМТ) є терапія, яка включає в себе ряд заходів, що направлені на спроможність попереджати розвиток та корегувати ускладнення від травми. Вибір лікарських засобів при травматичних ушкодженнях головного $є$ однією 3 найбільш складних проблем в комплексі лікування таких хворих. Деяким адамантанвмісним лікарським засобам, зокрема амантадину сульфату або гідрохлориду, мемантину, Адемолу притаманна антагоністична дія на NMDA-рецептори, що проявляється у збереженні морфо-функціонального стану нейронів на різних за генезом розвитку моделях ураження мозку. На сьогодні постало питання щодо ефективності препарату “Адемол” при черепно-мозковій травмі (ЧМТ) як церебропротектора для збереження структури цілісності нейронів головного мозку.

\section{META РОБОТИ}

Оцінити величину церебропротекторної дії різних доз Адемолу за показником летальності щурів на фоні експериментальної ЧМТ.

\section{МАТЕРІАЛИ ТА МЕТОДИ}

Оцінку церебропротекторних властивостей Адемолу проведено на 120 щурах-самцях масою 160-180 г. Експериментальна модель ЧМТ була викликана дією потоку вуглекислого газу. Терапевтичну дію Адемолу на модельній ЧМТ оцінювали при його застосуванні окремими дозами 1, 2 та 4 мг/кг двічі на добу з інтервалом 12 год впродовж 8-ми діб шляхом внутрішньовенної інфузії. Результати обробляли за допомогою статистичної програми StatPlus 2009. Використовували кутове перетворення Фішера при обліку результатів в альтернативній формі (летальність, виживаність). Відмінності вважали статистично значущими при $\mathrm{p}<0,05$.

\section{РЕЗУЛЬТАТИ}

У щурів груп контрольної патології, де в якості перманентної терапії вводили $0,9 \%$ розчин $\mathrm{NaCl}$ в дозах 1,2 та 4 мл/кг, показник смертності залишався стабільним $(\mathrm{p}>0,05)$ протягом 8 діб спостереження, з тенденцією до поступового збільшення. У групі щурів з ЧМТ $+0,9 \%$ $\mathrm{NaCl}(2$ мл/кг) більше половини тварин $(60 \%)$ загинуло упродовж перших 6 год від початку моделювання ЧМТ $(\mathrm{p}<0,05)$, що можна вважати за критичний рубіж для даної патології. При застосуванні Адемолу в дозах 1, 2 та 4 мг/ кг упродовж 8 діб модельної ЧМТ показник летальності на кінець періоду спостереження склав 35,30 та 50\% відповідно для трьох досліджуваних груп.

\section{висновки}

1. Скринінг найбільш ефективної церебропротективної дози Адемолу за показником летальності вказує на те, що максимальна терапевтична дія досліджуваного препарату проявилась при його застосуванні у дозі 2 мг/кг двічі на добу з інтервалом 12 год, яку можна вважати умовноефективною для модельної ЧМТ.

2. Терапія експериментальної ЧМТ Адемолом є ефективнішою за інфузію $0,9 \% \mathrm{NaCl}$ та достовірно сприяє зменшенню летальності у тварин на 8-му добу спостереження.

\section{СПИСОК ЛІТЕРАТУРИ}

1. Ходаківський О.А. Патогенетичне обтрунтування дочільност використання нових похідних адамантану при експериментальній терапії гострої ішемії головного мозку та міокарда (експериментальне дослідження): автореф, дис. д.медн. спеи. 14.03.05 “Фармакологія" / О.А. Ходаківський. - Одеса, 2014. - 24 c.

2. Черешнюк I.Л. Вилив блокаторів НМДА-речепторів на динаміку внутрішньоочного тиску у кролів. [текст]/I.Л. Черешнюк, О.І. Альвнутрішньоочного тиску у кролів. [текст]/I.Л. Черешнюк, О.І. Аль-
чук, Л.І. Маринич [та ін.]// Фізіол. журн. - 2017. - №1(63). - С. 69-76. 3. Ходакі. Маринич [та ін.] Фізіол. журн. - 2017. - №1(63). - С. 69-76. Ходаківський О.А. Скринінг иеребропротекторного ефекту серед нових похідних адамантану в умовах експериментальної ішемі головного мозку. [текст] П.А. Ходаківський, Г.І. Степанюк, Ю.В. Короткий, М.О. Лозинський// Фармакологія та лікар. токсиколо2is - 2010 - No3(16) - C. $8-11$. 


\title{
Середенко В.Г.
}

\section{АНЕСТЕЗІОЛОГІЧНЕ ЗАБЕЗПЕЧЕННЯ АМБУЛАТОРНИХ МАЛОІНВАЗИВНИХ ЕНДОСКОПІЧНИХ ОПЕРАТИВНИХ ВТРУЧАНЬ}

\author{
ДУ «Інститут медичної радіології ім. С.П. Григор'єва НАМН України » м. Харків
}

\section{АКТУАЛЬНІСТЬ}

Впровадження малоінвазивних ендоскопічних операцій та проведення діагностичних маніпуляцій обумовлює необхідність розробки сучасних методів їх анестезіологічного забезпечення.

\section{МАТЕРІАЛИ I МЕТОДИ}

Дослідження проведені у 227 пацієнтів, середній вік 54 $+8,2$ років. Чоловіків $120(52,9 \%)$, жінок $107(47,1 \%)$. Вибір методу анестезії був обумовлений такими особливостями: тривалість операцій чи діагностичної маніпуляції, положення хворого на лівому боці, відсутність вираженої больової стимуляції, труднощі з забезпеченням адекватного газообміну при маніпуляціях на шлунку і стравоході. Пацієнти були розділені на дві групи: I $(\mathrm{n}=101)$ - маніпуляції на товстій кишці, внутрішньовенна анестезія зі збереженням самостійного дихання: індукція пропофолом 2,5-3,5 мг / кг і фентанілом 0,1 мг, основний наркоз - пропофол 4-8 мг / кг / год. II (n = 126) маніпуляції на шлунку і стравоході, внутрішньовенна анестезія зі збереженням самостійного дихання пропофолом без знеболюючого препарата. Проводився стандартний неінвазивний моніторинг гемодинаміки, оксигенації, капнографії, визначались рівень глікемії, рівень кортизола.
В обох групах пацієнтів спостерігався гладкий перебіг анестезії. Гемодинаміка залишалася стабільною. Рівень седації під час маніпуляцій достатній. Вираженою глікемії не було. Вміст кортизолу залишився в межах функціональної норми (результат $-451,03+23,81$ та через 2 години $347,42+35,15$ нмоль / л). Рівень оксигенації у всіх хворих, на всіх етапах маніпуляцій був достатнім ( $\mathrm{SaO} 2$ 95$100 \%$ ). Була тенденція до помірної гіпокапніi.

\section{виводи}

Малоінвазивні ендоскопічні оперативні втручання та діагностичні маніпуляції на органах ШКТ, супроводжуються низьким рівнем ноцицептивної імпульсації, що дає можливість значно зменшити аналгетичний компонент анестезіологічного забезпечення.

\section{ЛITEPATУPA}

1. Green S.M. Unscheduled Procedural Sedation: A Multidisciplinary Consensus Practice Guideline. [text] \& Steven M. Green Mark G. Roback, Baruch S. Krauss, James R. Miner, Robert E. O'Connor: Robals of Emergency Medicine - 2019. - Vol 73 (5) - p. Connor.

Spruce L Back to Basics. Procedural Sedation [text] / Lisa Spruce / AORN Journal - 2015 - Vol. 101(3) - p.345-353.

\section{Середенко В.Г.}

\section{СПІНАЛЬНА АНЕСТЕЗІЯ ПРИ ПРОВЕДЕННІ ВИСОКОДОЗНОЇ БРАХІТЕРАПІЇ У ХВОРИХ НА РАК ПЕРЕДМІХУРОВОЇ ЗАЛОЗИ}

Центр медичної радіології "Гамма плюс»

\author{
ДУ «Інститут медичної радіології ім. С.П. Григор'єва НАМН України » м. Харків
}

\section{АКТУАЛЬНІСТЬ}

Розвиток апаратної бази і методів променевої терапії сприяло стрімкому зростанню використання радіотерапії в якості методу радикального і паліативного лікування у хворих на рак передміхурової залози,але питання вибору анестезіологічного забезпечення при брахітерапії висвітлені недостатньо.

\section{МАТЕРІАЛИ ТА МЕТОДИ}

Спінальна анестезія (СА) була застосована у 57 пацієнта у віці від 58 до 83 років. Ризик анестезії склав II-III ст. по ASA. Супутня патологія: ХОЗЛ відзначався у $61 \%$; у $65 \%$ - гіпертонічна хвороба, $16 \%$ хворих мали в анамнезі ГПМК і 14\% гострий інфаркт міокарда. Для проведення аналізу ускладнень СА була створена база персоніфікованих даних, статистичну значущість визначали за допомогою критерія Стьюдента, для наочності результатів дослідження розраховували показники відносного ризику RR (relative risk, risk ratio) .

\section{РЕЗУЛЬТАТИ}

Доопераційна інфузійна терапія в обсязі 6-10 мл / кг маси тіла кристалоїдними розчинами. Пункція в положенні сидячи на рівні L III-IV або L IV-V голкою Quinke $25 \mathrm{G}$, маркаїн в дозі 17,5-20 мг. Аналіз перебігу СА виявив що через 15 хвилин, рівень сенсорної блокади досягав в се- редньому ThX дерматома, а рівень симпатичної - ThVIII. 3 побічних ефектів артеріальна гіпотонія була у 12 хворих (21\%), факторами ризику іiі розвитку з'явився симпатичний блок вище рівня $\mathrm{ThV}-\mathrm{RR}=6,2$; іншим значущим фактором з'явився ризик анестезії III класу по ASA $-\mathrm{RR}=3,1$. Брадикардія виникла у 5 хворих $(9,6 \%)$, фактором ризику їі розвитку з'явилися вихідна ЧСС $<60$ уд/ $\mathrm{xB}-\mathrm{RR}=7,0$ і симпатичний блок вище рівня $\mathrm{ThV} \mathrm{RR}=$ 6,1. Синдром післяопераційної нудоти і блювоти був відзначений у 2 хворих $(3,5 \%)$. Корекція артеріальної гіпотонії проводилася тільки інфузійної терапією колоїдними розчинами, для корекції брадикардії 5 хворим застосовували атропін. Слід зазначити, що нами не було виявлено випадків виникнення постпункційного головного болю, що може бути пов'язано з використанням тонких спінальних голок у осіб, як правило, похилого та старечого віку. Невисокий відсоток виникнення артеріальної гіпотонії можна пояснити обмеженим рівнем симпатичної блокади знаходженням пацієнта в літотомічному положенні. Перебіг анестезії відзначався стабільною гемодинамікою, високим ступенем комфорту і збереженням контакту 3 пацієнтом, що має важливе значення, так як він знаходиться в спеціальній ізольованій операційній, яка відокремлена від анестезіолога. 


\section{виводи}

Таким чином CA можна розглядати в якості анестезії вибору при проведенні високодозової брахітерапії у хворих на рак передміхурової залози.

\section{ЛITEPATУPA}

1. Weiner A. B. Prostate Cancer. A Contemporary Approach to Treatment and Outcomes. [text] |/ A. B. Weiner, S. D. Kundu // Medical
Clinics of North America. - 2018. - vol.102, issue 2. - p. 215-229 https://doi.org/10.1016/j.mcna.2017.10.001

2. Frankart A J. Comparison of Spinal and General Anesthesia Approaches for MRI-guided Brachytherapy for Cervical Cancer. [text] / Andrew J. Frankart, Teresa Meier, Thomas L. Minges, Jordan Kharofa // Brachytherapy. - 2018. - Vol. 17, Issue 5. - p. 761-767. doi: 10.1016/j.brachy.2018.05.002.

УДК 618.4-089.5:617-089

\section{Середенко Н. П.}

\section{ДОСЛІДЖЕННЯ СТРЕС-ПРОТЕКТИВНИХ ЕФЕКТІВ РІЗНИХ МЕТОДІВ АНЕСТЕЗІЇ ПРИ АБДОМІНАЛЬНОМУ РОЗРОДЖЕННІ}

\section{АКТУАЛЬНІСТЬ}

Вибір методу анестезії (МА) при кесаревому розтині (КР) спрямований на забезпечення адекватного захисту організму матері і плоду від стрес-реакцій, викликаних хірургічною травмою. Динаміка рівня плазмової концентрації кортизолу (К), інсуліну (I), пролактину(П) та співвідношення кортизол/інсулін (К/I) $є$ адекватним відображенням реакції організму на стрес.

META РОБОТИ

Оцінка стрес-протективних ефектів різних МА при операції КР.

\section{МАТЕРІАЛИ І МЕТОДИ}

93 вагітних, які були розродженні КР, розподілені на 3 групи в залежності від МА: I (n=31) - загальна анестезія (ЗА) з використанням кетаміна, II $(\mathrm{n}=31)-3 \mathrm{~A}$ з використанням тіопентала натрію, III $(\mathrm{n}=31)$ - спінальна анестезія (CA) з інтратекальним введенням $0,5 \%$ розчину бупівакаїну. Досліджували рівень глікемії, К, I, П імуноферментним методом, розраховували К/І. Інтенсивність больового синдрому (БС) оцінювалась за допомогою візуальної аналогової шкали (ВАШ). Оцінка проводилася на 5 етапах: 1 - вихідний; 2 - початок операції; 3 - етап вилучення плода; 4 - через 6 годин; 5 - через 12 годин після закінчення операції.

\section{РЕЗУЛЬТАТИ}

При дослідженні гормональної ланки не було виявлено статистично значущих міжгрупових відмінностей у вихідному рівні (ВР) К, П, І. Достовірно вищим був ВР глюкози в I і ІІгрупах $(\mathrm{p}<0,001)$. Рівень I на 3 -му етапі в I групі знизився на 20\% $(\mathrm{p}<0,05)$, в II групі на $25 \%$ $(\mathrm{p}<0,05)$ від ВР, в III групі рівень I наближався до ВР та залишався без істотних коливань до 4-го етапу.

Рівень К на 3-му етапі збільшився до $826,3 \pm 50,8$ нмоль/л $(\mathrm{p}<0,001)$ в I групі та до $922,5 \pm 52,5$ нмоль/л в II групі $(\mathrm{p}<0,001)$. На 4-му етапі в групах I і II рівень K на $34 \%$ був вище ніж в III групі $(p<0,05)$. На 3 -му етапі встановлено високий K/I в I та II групах $(1,47 \pm 0,1$ та $1,85 \pm$ $0,2)$, в III групі - статистично незначне підвищення K/I 3 нормалізацією к 4-му і 5-му етапам.

Виявлено збільшення рівня П в І групі на $51 \%$ $(\mathrm{p}<0,001)$ та на $47 \%$ в II групі $(\mathrm{p}<0,001)$, приріст П у пацієнток III групи залишився статистично незначущим.

Інтенсивність БС за ВАШ наростала к 4-му етапу у пацієнток усіх груп. Найвищою вона була в I і II групах: $5,2 \pm 0,2$ см $(\mathrm{p}<0,001)$ та 5,4 $\pm 0,2$ см $(\mathrm{p}<0,001)$, відповідно, що достовірно відрізнялось від рівня БС в ІІІ групі $3,5 \pm 0,2$ см. На 5-му етапі БС зменшувався у пацієнток усіх груп, достовірно вищим він був у пацієнток I і II групи $(3,6 \pm 0,1 \mathrm{~cm} \mathrm{i} \mathrm{4,0 \pm 0,1см,} \mathrm{відповідно)} \mathrm{в} \mathrm{порівнянні}$ 3 III групою $-2,5 \pm 0,1$ см $(\mathrm{p}<0,001)$.

\section{висновки}

Динаміка вмісту стрес-гормонів, рівня БС у пацієнток, розроджених КР в умовах СА дає підстави вважати даний МА оптимальним і адекватним в якості захисту від хірургічного стресу.

СПИСОК ЛІТЕРАТУРИ

1. N. Kiriakopoulos et al., Investigating Stress Response during Vaginal Delivery and Elective Cesarean Section through Assessmen of Levels of Cortisol, Interleukin 6, Growth Hormone and Insulin-Like Growth Factor 1, J. Clin. Med. 2019, 8, 1112

\section{Середенко В.Г.}

\section{ПІСЛЯОПЕРАЦІЙНИЙ БІЛЬ В СТОМАТОЛОГІЇ, ВАРІАНТИ ЗНЕБОЛЮВАННЯ,ЩО КРАЩЕ ДЛЯ ПАЦІЄНТА?}

Стоматологічна клініка Шелеста м. Харків

\section{АКТУАЛЬНІСТЬ}

Кожного року зростає кількість проведених загальних знеболювань та седацій в приватних стоматологічних клініках. Але після проведеного оперативного втручання виникає питання адекватної аналгезії так як пацієнт буде знаходитись поза межами клініки.

\section{META}

Виявити ефективні і безпечні методики післяопераційного знеболювання після проведених оперативних втручань в амбулаторній стоматології.

\section{МАТЕРІАЛИ І МЕТОДИ}

Залежно від схеми післяопераційного знеболювання виділені 3 групи (по 50 чол. В кожній) з ризиком ASA 1-2 ст. Всім виконувалися амбулаторні операції: екстракція одного або декількох зубів, імплантація зубів, видалення кісти і т.д. У всіх хворих застосовувалась регіонарна анестезія з використанням місцевих анестетиків 3 проведенням седації пропофолом. Після закінчення необхідного періоду спостереження, пацієнти виписувалися додому. Рівень болю визначали за шкалою ВАШ при його появі та через 1 годи- 
ну після прийому анальгетиків. У пацєнтів 1-ї групі застосовували декскетопрофен (Дексалгін) по 50 мг в/м при виникненні болю $з$ подальшим застосуванням в дозуванні 25 мг per os кожні 8 годин. У пацієнтів 2-ої групи застосовували еторикоксиб (Аркоксія) в дозуванні 90 мг per os 1 раз на добу протягом 3 діб. У пацієнтів 3-ої групі був використаний німесулід (Німесил) в дозуванні 100 мг per os при виникненні болю, далі по 100 мг кожні 12 годин.

\section{РЕЗУЛЬТАТИ ДОСЛІДЖЕННЯ}

У всіх групах якість знеболювання була оцінена як задовільна. Рівень болю за шкалою ВАШ був 1-2 бали (клінічно незначний). Важливим є висока якість аналгезії в групах 2 та 3, де застосовувалися пероральні форми анальгетиків, що давало можливість пацієнтам використовувати іï в домашніх умовах.

\section{вИСновки}

Методики аналгезії з використанням парентерального введення НПЗП з переходом на оральні форми є ефективні i безпечні для амбулаторної стоматологічної практики, а використання тільки оральних форм надає переваги та додаткові зручності для хворим.

\section{ЛITEPATУРA}

1. Talavбn-Serna J. Implication of general anaesthetic and sedation techniques in temporomandibular joint disorders - a systematic review.[text] /J. Talavбn-Serna, J. M. Montiel-Company, C. BellotArchs, J. M. Almerich-Silla // Journal of Stomatology, Oral and Maxillofacial Surgery. - 2017. - Vol. 118, Issue 1. - p. 40-44.

2. Sigaux $N$. Efficacy of the postoperative management after microsurgical free tissue transfer [text] /N. Sigaux, P. Philouze, $F$ Boucher, M. Jacquemart, P. Breton// Journal of Stomatology, Oral and Maxillofacial Surgery. - 2017. -Vol.118, Issue 3. - p. 173-177

УДК 616.329-006.6-089.5-089.168

\section{Сидюк О. Є.}

\section{ЗНЕБОЛЕННЯ ПІСЛЯ ТОРАКАЛЬНИХ ОПЕРАТИВНИХ ВТРУЧАНЬ}

Національний інститут хірургії і трансплантології ім. О.О. Шалімова.

\section{АКТУАЛЬНІСТЬ ПРОБЛЕМИ}

Торако-абдомінальний доступ - одна з найбільш болючих хірургічних маніпуляцій, яка асоціюється з значною післяопераційною дисфункцією діафрагми і респіраторними порушеннями. Торакальна епідуральна анестезія (TEA) - найбільш широко використовувана методика для менеджменту післяопераційного болю у пацієнтів після торакотомії, яка була прийнята в світі в якості «золотого стандарту». Однак, ТЕА іноді може асоціюватися зі значними клінічними ускладненнями, такими як гіпотензія, затримка сечовипускання і навіть респіраторними ускладненнями через ослаблення дихальних м'язів, і може також бути пов'язана 3 гіршими прогнозами після пневмонектомії. Торакальний паравертебральний блок (ПВБ) може бути альтернативою для пацієнтів після торакотомії, у яких бажано вживати лише односторонній сенсорний блок.

\section{META РОБОТИ}

Покращити результати анестезіологічного забезпечення торакальних операцій шляхом розробки і застосування методу раціонального післяопераційного знеболення.

\section{МАТЕРІАЛИ I МЕТОДИ}

У дослідження включені 90 хворих, оперованих в HIXT ім. О.О. Шалімова 3 приводу злоякісних пухлин грудної порожнини, яким були виконані радикальні оперативні втручання комбінованим торако-абдомінальним доступом (Льюїса або Осава-Гарлока). Використана роз- роблена методика комбінованої післяопераційної аналгезії (ТЕА + ПВБ).

\section{РЕЗУЛЬТАТИ}

Розроблена методика сприяла зменшенню дози опіоїдних анальгетиків для післяопераційного знеболення. Застосування комбінованого паравертебрального та епідурального блоку для післяопераційного знеболення сприяло стабільним показникам гемодинаміки, меншою мірою негативно впливає на функціональні показники зовнішнього дихання та може бути безпечно використовуватися в щоденної клінічної практики.

\section{висновки}

Розроблена і впроваджена методика дозволяє підвищити безпеку хворих під час виконання оперативних втручань, сприяє зменшенню кількості ускладнень та підвищує ефективність і комфорт пацієнтів в періопераційному періоді.

\section{СПИСОК ЛІТЕРАТУРИ}

1. Kobayashi R. Paravertebral block via the surgical field versus epidural block for patients undergoing thoracotomy: a randomized clinical trial. [text] $R$. Kobayashi, S. Mori, K. Wakai, K. Fukumoto, T. Saito, T. Katayama et al. // Surgery Today. - 2013. - 43. - p. 963969 .

2. Yokoyama Y. Combined analgesic treatment of epidural and paravertebral block after thoracic surgery. [text] / Y. Yokoyama, $T$ paravortebral D. Shikata, T. Goto // J Thorac Dis. - 2017. - vol.9(6). p.1651-1657.

p.1651-1657.
Rosero E.B. Nationwide incidence of serious complications of epidural analgesia in the United States. [text] / E.B. Rosero, G.P. Joshi //Acta Anaesthesiol Scand. - 2016. - vol. 60(6). - p. 810-820.

\section{ДИНАМІКА ЛАБОРАТОРНИХ ПОКАЗНИКІВ КРОВІ ВНУТРІШНЬОЇ ЯРЕМНОЇ ВЕНИ ПІД ЧАС ОПЕРАТИВНИХ ВТРУЧАНЬ НА СОННИХ АРТЕРІЯХ}

Військово-медичний клінічний центр Західного регіону

\section{ВСТУп}

Низький церебральний гемодинамічний резерв, характерний для пацієнтів з ураженням каротидного басейну, значно знижує їх толерантність до тимчасового перекривання кровоплину під час оперативних втручань на сон- них артеріях. На сьогодні не існує точних та доступних методів передопераційної оцінки резерву мозкового кровообігу, що ускладнює прогнозування перебігу інтраопераційного припинення кровоплину у внутрішній сонній артерії (BCA). 


\section{META РОБОТИ}

Дослідити динаміку газового складу крові, концентрацій глюкози та лактату у крові з іпсілатеральної внутрішньої яремної вени (ВЯВ) під час проведення оперативних втручань на каротидному басейні.

\section{МАТЕРІАЛИ ТА МЕТОДИ}

Дослідження виконано на базі клініки хірургії серця та магістральних судин та клініки лабораторної діагностики Військово-медичного клінічного центру Західного регіону. У дослідження увійшли 48 пацієнтів (чоловіки/жінки = 33/15) віком від 18 до 76 років, що потребували хірургічного лікування з приводу патологічної звивистості (17 чол.), атеросклеротичного стенозу (19 чол.) та поєднання обох варіантів патології ВСА (12 чол). Оперативні втручання виконували під місцевою анестезією з поверхневою аналгоседацією, що забезпечувало можливість неврологічного моніторингу та чіткої діагностики розвитку інтраопераційної церебральної ішемії. Забір крові з ВяВ виконували до перетискання загальної сонної артерії (ЗагСА) та одразу після відновлення кровообігу у ВСА. Середній час перетискання ЗагСА становив 39 хв $\pm 2,77$ хв.

\section{РЕЗУЛЬТАТИ}

Виявлено достовірне зниження середнього значення парціального тиску кисню у ВЯВ $\left(\mathrm{p}_{\mathrm{vj}} \mathrm{O}_{2}\right)$ на $6,7 \%$ протягом періоду перетискання ЗагСА на іпсілатеральній стороні $(\mathrm{p}=0,0089)$. Проте, у частини пацієнтів спостерігалось зростання даного показника. Отримано достовірний позитивний кореляційний зв'язок для ступеня зміни $\mathrm{p}_{\mathrm{vj}} \mathrm{O}_{2}$ зі зміною концентрації глюкози у ВЯВ $(\mathrm{p}=0,037)$, а також негативний - 3 віком пацієнтів ( $\mathrm{p}=0,049)$. Час перетискання ЗагСА достовірно позитивно пов'язаний з концентра-

цією глюкози у ВЯВ, яка була визначена після відновлення кровообігу $(\mathrm{p}=0,045)$, що може бути пов'язано з реакцією організму на операційний стрес. Значення $\mathrm{pH}$, отримане після пуску кровообігу у ВСА, достовірно негативно корелює із зміною концентрації глюкози у ВЯВ за час перетискання ЗагСА $(\mathrm{p}=0,01)$, а також 3 парціальним напруженням $\mathrm{CO}_{2}$ у ВЯВ, отриманим до перетискання ЗагСА ( $\mathrm{p}=0,003)$, що показує розвиток більш глибокого ацидозу за час перетискання ЗагСА у пацієнтів, аеробне окиснення глюкози яких протікає більш інтенсивно до моменту перетискання ЗагСА. Виявлено достовірний негативний кореляційний зв'язок показника $\mathrm{pH}$ з концентрацією лактату у ВЯВ, отриманих після пуску кровоплину у BCA $(\mathrm{p}=0,03)$, що свідчить на користь розвитку лактат-ацидозу, а не використання лактату в якості альтернативного енергетичного субстрату за умов зниженого кровопостачання головного мозку.

\section{висновки}

Різноспрямована зміна $\mathrm{p}_{\mathrm{vj}} \mathrm{O}_{2}$ може бути пов'язана 3 порушенням механізмів засвоєння кисню та основних енергетичних субстратів головним мозком протягом короткочасного унілатерального припинення кровообігу у ВСА. Диференційовані підходи до тактики анестезіологічного забезпечення та медикаментозної церебропротекції під час оперативних втручань на каротидному басейні повинні включати оцінку не лише таких факторів як вік, ступінь вираження судинної патології, наявність супутньої патології, а й враховувати можливі зміни кисневого гомеостазу, балансу кислотно-основної рівноваги та інтенсивності утилізації основних субстратів окиснення у відповідності до напруження адаптаційно-пристосувальних механізмів компенсації церебральної ішемії.

\section{Тєлушко Я.В., Перцов В.І., Троян Г.С.}

\section{АНЕСТЕЗІОЛОГІЧНЕ ЗАБЕЗПЕЧЕННЯ ВІДЕОТОРАКОСКОПІЧНИХ ОПЕРАЦІЙ ПРИ АБСЦЕСІ ЛЕГЕНЬ}

\section{АКТУАЛЬНІСТЬ}

Сучасна тенденція застосування відеоторакоскопії при запальних захворюваннях легень дозволяє зробити втручання 3 мінімальною хірургічною травмою [1]. Постає питання про мінімізацію втручань для анестезіологічного забезпечення цієї процедури, як то відмова від штучної вентиляції легень та загального знеболення [2].

\section{META РОБОТИ:}

Визначити періопераційну тактику анестезіологічного забезпечення хворих з абсцесом легень.

\section{МАТЕРІАЛИ ТА МЕТОДИ}

Проаналізовано тактику анестезіологічного забезпечення 18 хворих 3 абсцесом легень, яким виконувалася відеоабсцесоскопія. Гендерний склад хворих: чоловіків 15 (83,3 \%), жінок $3(16,7 \%)$. Середній вік $58 \pm 14,3$ роки. За ASA хворі розподілилися: I клас - 16,6 \% випадків, II - 66,8 \%, III - 16,6 \% [4]. Хірургічне забезпечення: відеоендоскопічний комплекс «Karl Shtorz», Німеччина; через 2 торакопорти діаметром 5 мм у положенні пацієнта на здоровому боці. Після введення гіпнотиків та опіоїдних анальгетиків підтримання спонтанної вентиляції легень відбувалося за допомогою орофарингеального повітроводу з подачею зволоженого кисню (2-3 л/хв) через маску. Обов'язковою умовою аналгезії під час втручання було використання всього комплексу мультимодального знеболення (НПЗП, паравертебральна провідникова блокада під УЗД контролем та парацетамол). В післяопераційному періоді муль- тимодальне знеболення (НПЗП та парацетамол) проводилося 48 годин, далі анальгетик вводили за потребою.

\section{РЕЗУЛЬТАТИ}

За ВАШ больовий синдром на $6,24,48$ годину мав чітку позитивну динаміку $7 \pm 1,2$ до $3 \pm 0,8$ балів $(\mathrm{p}<0,05)$ Усі хворі пройшли тестування WHOQoL-Brief [5]: післяопераційний стан у різних сферах життя оцінювався як задовільний (16,6 $\%)$ та добрий $(66,8 \%)$, на що впливають динаміка процесу та термін видалення дренажу. Післяопераційної пневмонії та ателектазу протилежної легені не відзначено, завдяки збереженню кашльового рефлексу та відсутності травматизації, що може бути наслідком інтубації трахеї.

\section{ВИСНОВКИ}

Поєднання методів періопераційного мультимодального знеболення зі спонтанною вентиляцією є достатніми при проведенні відеоабсцесоскопії з отриманням задовільних та хороших безпосередніх та віддалених результатів у 83,4 \% та знижує ризик післяопераційних ускладнень.

\section{СПИСОК ЛІТЕРАТУРИ}

1. Akopov A, Egorov V, Deynega I, Ionov P. Awake video-assisted thoracic surgery in acute infectious pulmonary destruction. Ann Transl Med. 2015. Vol. 3. № 8 . P.100

2. Tacconi F, Pompeo E. Non-intubated video-assisted thoracic surgery: where does Ptand? J Thorac Dis. 2016. Vol. 4. N. 8. P. 364-375.

3. ASA physical status classification system : веб-caüm URL. https://www asahq org/ standards-and-guidelines lasa-physical-status-classification-system (dama нення: 18.07 .2019 .

4. Краткий опросник ВОЗ для оценки качества жизни: веб-сайт. URL: https:// Краткии опросник ВО3 для оценки качества жизни: веб-сайт. URL: https:/ звернення: 18.07.2019). 


\section{Timoв І.І., Мартин А.Ю., Вінтоняк І.В., Данилюк Т.Т., Венгрович В.В., Нестор I.I. \\ НОЗОКОМІАЛЬНІ СИНУСИТИ У ПОТЕРПІЛИХ 3 ЧЕРЕПНО-МОЗКОВОЮ ТРАВМОЮ}

\begin{abstract}
АКТУАЛЬНІСТЬ
Нозокоміальний синусит (НС) - гостре запалення приносових пазух носа, яке розвивається щонайменше через 48-72 години з моменту поступлення у BIT та обтяжує перебіг основного захворювання, загрожуючи розвитком вторинного бактеріального менінгоенцефаліту. Особливого значення ця проблема набуває у хворих, яким проведена назотрахеальна інтубація трахеї, введено назогастральний зонд, проведена тампонада носоглотки тощо. За спостереженнями А.Б. Туровського та Ю.В. Талолайко (2009) біля 90\% хворих мають комп’ютерно-томографічні зміни з боку приносових пазух носа після семиденного терміну інтубації чи встановлення назогастрального зонда.
\end{abstract}

META

Встановити частоту розвитку НС у потерпілих з ЧМТ, бактеріальних збудників та їх чутливість до антибактеріальних середників.

\section{МАТЕРІАЛ І МЕТОДИ}

Клінічні підозри стосовно нозокоміального синуїту виникають у випадках гарячкування хворого, коли найчастіші причини гарячки (пневмонія, ендокардит, емпієма плеври, катетерна інфекція, пієлонефрит, пролежні) заперечені. Спостерігали 483 потерпілих з ЧМТ на предмет виявлення проявів НС. Аспірат приносових пазух аналізували за допомогою бактеріологічного аналізатора «Vitek 2» (Франція)

\section{РЕЗУЛЬТАТИ}

За нашими даними, біля 10\% пацієнтів загальних відділів інтенсивної терапії і 35-38\% нейроінтенсивної терапії мають прояви НС. Для підтвердження діагнозу найбільш інформативна КТ-діагностика, при якій патологічні зміни з боку приносових пазух носа знаходять у середньому в $72 \%$ хворих, при цьому пансинуїт виявляють у $8,8 \%$, гемісинуїт у 90,9\%. При пункційній ревізії пазухи отриманий вміст чи промивні води передавали для бактеріологічного дослідження. При цьому бактеріальний збудник був ідентифікований у $64 \%$ випадків. 3 них час- тина зразків аспірату (34,6\%) мали 1 збудник, а решта 194 - полімікробну асоціацію. Виявлено Грам-позитивні збудники (Staphylococcus aureus, Streptococcus epidermidis, Streptococcus pyogenes, Streptococcus viridans) y 16,1\% випадків, а Грам-негативну флору (Pseudomonas aeruginoza, E. Coli, Pseudomonas cepacia, Klebsiella pneumonia, Enterobakter aerogenes) у 49,5\% досліджень. Серед виділених збудників більшість відзначалася поліантибіотикорезистентністю. Серед потерпілих, у яких було діагностовано НС, з метою санації запального вогнища у $8,2 \%$ проведено ендоскопічні оперативні втручання. Для лікування діагностованого НС найчастіше застосовували наступні комбінації (Ванкоміцин+Амікацин, Ванкоміцин+Цефтазидим+Амікацин, або монотерапію Коломіцином, Меропенемом чи Цефтобіпролом). Для успішного лікування великі надії покладаються на удосконалення уже існуючих (цефтазидим/авібактам, іміпенем/циластатин/peлебактам, азтреонам/авібактам, меропенем/ваборбактам) та нових антибіотиків i, особливо, моноклональних антитіл.

\section{вИСНОВки}

Для попередження розвитку НС у реанімаційних хворих необхідно застосовувати припідняте на $30^{\circ}$ положення голови, проведення назотрахеальної інтубації трахеї лише за строгими показами, трансоральне введення шлункового зонду у коматозних та седованих хворих під час штучної вентиляції легень, видалення назогастрального зонду на ніч, дотримання синоназальної гігієни тощо. Для вчасної діагностики НС у потерпілих з ЧМТ оптимально при кожному проведенні КТ обов'язково сканувати приносові пазухи носа.

\section{СПИСОК ЛІТЕРАТУРИ}

1. Соломкин В.Н. Параназальные синуситы у больных в отделении ре анимации /Журн. ушных, носовых, горловых болезней - 2000. - 츤 2. - C. $81-83$.

2. Крюков А.И. Особенности лечебно-диагностической тактики при нозокомиальном синусите в отделениях реанимации и интенсивной терапии крупного многопрофильного стационара /А.И. Крюков, А.Б. Туровский, И.С. Абдулаев //Вестн. оторинолар. - 2008. ков, А.Б. Туров - C. $30-33$.

Точило С.A

\section{УРОВЕНЬ СЫВОРОТОЧНОГО ЖЕЛЕЗА И РАЗВИТИЕ СИНДРОМА ПОЛИОРГАННОЙ НЕДОСТАТОЧНОСТИ У ПАЦИЕНТОВ В ПЕРИОПЕРАЦИОННОМ ПЕРИОДЕ}

УЗ «Могилевская областная больница», Могилев, Беларусь

\section{ВВЕДЕНИЕ}

В последнее время наблюдается пристальное внимание исследователей к проблеме периоперационной анемии. Установлено, что она увеличивает риск летального исхода и послеоперационных осложнений. Грозным осложнением является синдром полиорганной недостаточности $(\mathrm{CПОН})$. Однако роль дефицита сывороточного железа в развитии данной патологии изучена недостаточно.

\section{ЦЕЛЬ ИССЛЕДОВАНИЯ}

Определение уровня сывороточного железа в периоперационном периоде у пациентов с эндопротезировани- ем крупных суставов, а также с наличием СПОН в абдоминальной хирургии.

\section{МАТЕРИАЛЫ И МЕТОДЫ}

Проведено проспективное когортное исследование у 77 пациентов, из них 18 мужчин и 59 женщин, возраст $61,9 \pm 15,1$ лет. Были выделены две группы: 1-я (контрольная) - пациенты после эндопротезирования крупных суставов (n=40), 2-я (основная) - пациенты в абдоминальной хирургии с наличием СПОН $(\mathrm{n}=37)$. Наличие $\mathrm{CПOH}$ устанавливали на основании критериев согласительной конференции SCCM/ACCP 2016 г. 
Контролировали показатели сывороточного железа с применением анализатора AU 680 (США). В исследовании выделено несколько этапов: 1-й - до операции, 2-й - 1-е сутки после операции, 3-й - 3-и сутки, 4-й - 7-е сутки, 5й - 10-е сутки. Статистическую обработку производили с применением программ Ms Excel и Statistica 7.0.

\section{РЕЗУЛЬТАТЫ}

Пациенты в группах не имели различий по полу, возрасту, массе тела, росту. Хирургическая патология у пациентов 2-й группы: острый панкреатит -8 , хронический панкреатит -5 , холедохолитиаз - 11 , мезентериальный тромбоз - 4, перитонит - 3, язвенная болезнь с кровотечением - 3, с перфорацией -3 . Им выполнялись операции: лапаротомии -29 , лапароскопии -4 , релапаротомии -4

При изучении показателей сывороточного железа установлено его значимое снижение $(\mathrm{p}<0,05)$ в послеоперационном периоде. В 1-й группе: 1-й этап - 15,2 (10-19,4) мкмоль/л, 2-й этап - 5,2 (3,9-7,6) мкмоль/л, 3-й этап - 6,6 $(5-8,7)$ мкмоль/л, 4-й этап - 9,7 $(8,6-12,1)$ мкмоль/л, 5-й этап - 9,4 $(7,8-11,9)$ мкмоль/л. Во 2-й группе: 1-й этап -
11,9 (10-15) мкмоль/л, 2-й этап - 3,7 (1,7-4,1) мкмоль/л, 3 -й этап - 3,6 (2,4-4,5) мкмоль/л, 4-й этап - 6,5 $(4,4-8,2)$ мкмоль/л, 5-й этап - 7,6 (6,5-9,4) мкмоль/л. При этом в обеих группах железо повышалось на 4-м этапе против 2 -го этапа $(\mathrm{p}<0,05)$. При сравнении уровня железа между группами обнаружены значимые отличия $(\mathrm{p}<0,05)$ на 2 -м, 3-м и 4-м этапах.

\section{выводы}

У пациентов в послеоперационном периоде наблюдается снижение сывороточного железа, уровень которого повышается к 7-м суткам, но исходных значений не достигает. Данное снижение в большей степени выражено у пациентов с наличием СПОН после абдоминальных хирургических вмешательств.

\section{ЛИТЕРАТУРА}

1. Приходько В.Ю. Железодефицитная анемия - синдром, требующий настороженности врача // Мистещтво лікування. - 2011. No 5-6 (81-82). - C. 4-11.

2. Рогачевский О.В., Моисеев С.В. Клиническое значение и лечение анемии в предоперачионном периоде // Клиническая фармакология и терапия. - 2014. - №2. - C. 55-60.

3. Litton E., Lim J. Iron Metabolism: An Emerging Therapeutic Targe in Critical Illness. // Critical Care. - 2019. - Vol. 23 - No1. - P. 81.

\section{Тхоревський О.В., Пачехон О.В. \\ СПОСОБИ ЗАБЕЗПЕЧЕННЯ ПРОХІДНОСТІ ДИХАЛЬНИХ ШЛЯХІВ ТА ВЕНТИЛЯЦІЇ ПРИ ОПЕРАТИВНИХ ВТРУЧАННЯХ В ЩЕЛЕПНО-ЛИЦЬОВІЙ ХІРУРГІЇ}

Українська військово-медична академія, Київ, Україна.

Після початку активних воєнних дій на сході України НВМКЦ "ГВКГ” приймає активну участь в наданні кваліфікованої та спеціалізованої медичної допомоги постраждалим ЗСУ та інших силових структур України. Активна участь у вигляді консультативної медичної допомоги надавалась міжнародною медичною спільнотою, зокрема в клініці ЩЛХ та нейрохірургії працювала група медиків 3 Канади. За час АТО канадськими спеціалістами було здійснено 5 місій щодо допомоги пораненим в зоні АТО.

Анестезії при операціях в щелепно-лицевій ділянці відносяться до категорії високого ризику складності, що обумовлено особливостями анестезіологічного забезпечення в щелепно-лицевій хірургії. При цьому на перший план виходить проблема забезпечення і підтримки прохідності дихальних шляхів і здійснення респіраторної підтримки.

Операції на щелепно-лицьовій ділянці можна віднести до предикторів складних дихальних шляхів. При наявності поранень, дефектів в зоні ротової порожнини та носа та новоутворень в цих ділянках не завжди можлива вентиляція через лицеву маску, навіть під час ввідної анестезії.

\section{МЕТА ДОСЛІДЖЕННЯ}

Підвищити безпеку анестезіологічного забезпечення реконструктивних втручань у щелепно-лицьовій хірургії шляхом вибору оптимального способу забезпечення прохідності дихальних шляхів в передопераційному періоді.

В результаті співпраці з зарубіжними фахівцями нами виявлено деякі особливості надання спеціалізованої медичної допомоги, а саме:

1. Етап премедикації. Не застосовується атропін, профілактика післяопераційного делірію. При необхідності застосовують глікопіролат. На етапі премедикації канадськими фахівцями широко використовуються легкі гіпнотичні засоби (бензодіазепіни) - мідазолам (доза 5 мг в 1 мл в/в за 5-10 хв. до індукції анестезії; розрахункова доза 0,07-0,1 мг/кг, середня доза 7,5-15 мг). Завдяки цьому досягається снодійна, незначна міорелаксуюча та антеградно-амнестична дія. Перед великими втручанням за 1-2 години пацієнти отримують прегабалін 1 капсула (50 мг), парацетамол 500 мг, целекоксиб 100 мг.

2. Індукція анестезії виконується шляхом в/в введення $1 \%$ розчину пропофолу в дозі $2-2,5$ мг/кг, фентанілу в дозі 3-5 мкг/кг без використання атропіну. Міоплегія для інтубації трахеї забезпечується рокуронієм бромідом (есмерон) в дозуванні 0,6 мг/кг, який вводиться після досягнення хірургічної стадії наркозу (стадія III.1 за Гведелом).

3. Для підтримання основного етапу анестезії - широко застосовуються інгаляційні анестетики, зокрема севофлуран в концентрації 2-6\%. 3 метою поглиблення анестезії застосовують в/в пропофол та наркотичні анальгетикі (фентаніл). Звертає увагу факт того, що інтраопераційна середня доза пропофолу (канадського виробника) складала 1650+120 мг, пробудження хворого через 10-15 хв., а середня доза пропофолу (українського виробника) $749,5 \pm 70,5$ мг, пробудження - 30-40 хв.

4. Для виконання поставленої мети - безпечного захисту дихальних шляхів під час реконструктивних втручання із посттравматичними дефектами та деформаціями щелепно-лицевої ділянки у досліджених хворих $(\mathrm{n}=150)$ застосовували ларінгеальні маски 2-го покоління $(\mathrm{n}=20)$, інтубацію трахеї через рот $(\mathrm{n}=100)$, 3 них 25 за допомогою фіброоптичних засобів (“Glidescope", “Airtraq"), інтубація трахеї через ніс $(\mathrm{n}=30)$. Моніторинг безпечної вентиляції відбувалось завдяки показникам $\mathrm{SaO}_{2}$, капнографії, контроль peak inspiratory pressure (на рівні $20-25 \mathrm{~cm} \mathrm{H}_{2} \mathrm{O}$. 


\section{висновки}

1. При реконструктивних втручаннях на лицьовій та орбітальній ділянці можна застосувати ларінгеальні маски 2-го покоління, які мають мінімальний вплив на серцевусудинну систему при встановленні та забезпечують комфортне пробудження.

2. Надійним та безпечним засобом забезпечення прохідності дихальних шляхів при операціях на щелепній ділянці були інтубація трахеї через рот або ніс з розду-

ванням манжетки, але важка інтубація складала $19,2 \%$, яка виконувалась за допомогою фіброоптичних засобів ("Glidescope”, “Airtraq", фібробронхоскопу).

\section{СПИСОК ЛІТЕРАТУРИ}

1. Алгоритмы при трудной интубации и экстубации трахеи :моно графия / О. А. Тарабрин, В. В. Суслов, А. А. Буднюк,И. Л. Басенко. Odecca, 2012. - 140 c.

2. Stroumpoulis K. Videolaryngoscopy in the managemen to the difficult airway: a comparisonwiththe Macintosh blade / K. Stroumpoulis, A. Pagoulatou, M. Violari [etal.] // Eur. J. Anesthesiol. - 2009. -Vol. $26-P .218-222$

\section{Фрончко В.П., Іванюшко О. В., Шевченко С. Б. Семицький Я. В., Мельник Р. В. ПРАКТИЧНІ ПИТАННЯ ПРОВЕДЕННЯ НУТРИТИВНОЇ ТЕРАПІЇ}

Міська клінічна лікарня, Луцьк, Україна

Львівський Національний Медичний Університет імені Данила Галицького

\section{АКТУАЛЬНІСТЬ ПРОБЛЕМИ}

Важливу роль в патогенезі порушень раннього постагресивного періоду займає синдром гіперметаболічного катаболізму, який формується у 100\% важких і критичних хворих. Сучасна стратегія проведення нутритивної терапії базується на протоколі PEP UP (Enhanced ProteinEnergy Provision via the Enteral Route Feeding Protocol in Critically Ill Patients), що передбачає більш швидке досягнення добових цільових значень білково-енергетичного забезпечення, [1, 2].

\section{META РОБОТИ}

Підвищення ефективності нутритивної терапії на основі протоколу PEP UP шляхом проведення ентерального і парентерального харчування у хворих BAIT.

\section{МАТЕРІАЛИ I МЕТОДИ}

Під спостереженням знаходились 26 хворих (8 пацієнтів $з$ політравмою, 5 з церебральною патологією, 53 сепсисом, 4 після оперативних втручань на шлунковокишковому тракті, 2 з опіковою хворобою, 2 з хронічною серцево-легеневою патологією), які потребували тривалої нутритивної терапії. Годування хворих здійснювалось рідкими ентеральними сумішами Фрезубін енергія та Пептамен. Парентеральне харчування проводили сумішами Нутріфлекс.

Цільові значення харчування наступні: білок 1,22 г/кг/добу, енергія 25-30 ккал/кг; бажаним було досягнення більше $80 \%$ добово-енергетичного забезпечення вже на 3-ю добу. Порівнювали розраховане та реально забезпечене білково-енергетичне відшкодування пацієнтів. Оцінювали рівень глікемії, вміст загального білка, альбуміну, абсолютної кількості лімфоцитів.

\section{РЕЗУЛЬТАТИ}

На 3-ю добу лише у 7 хворих показник білково-енергетичного забезпечення склав $80 \%$ і більше від необхідного. В інших пацієнтів цей показник визначався в межах 40-75\%. На 5 добу більше $80 \%$ білково-енергетичного відшкодування вдалось досягнути у 12 хворих. Мінімальне трофічне харчування застосовували у хворих, які вимагали вазопресорної підтримки. Пацієнтам з високим рівнем катаболізму, починаючи з 6-7 доби, проводили поєднане харчування. Протягом перших 7 днів хворі отримали $0,7-1,5$ г/кг/добу білка. Кількість отриманого білка на 14 добу зросла до 1,0-1, 7 г/кг.

В цілому білково-енергетичний дефіцит протягом першого тижня складав $40 \%$, в період від 8 до 14 доби $20-25 \%$ від розрахованих показників. Рівень загального білка на 3 добу склав 46-62 г/л, на 5 добу - 48-62 г/л, на 7 добу - 50-68 г/л.

\section{ВИСНОВкИ}

Основним фактором, що обмежує адекватне білковоенергетичне забезпечення на ранньому етапі, $є$ синдром інтестинальної недостатності. Тривалі підвищені втрати азоту та наявність інтестинальної недостатності різної вираженості вимагають проведення поєднаного харчування 3 метою досягнення цільових значень білково-енергетичного відшкодування.

\section{СПИСОК ЛІТЕРАТУРИ}

1. Early Administration of Protein in Critically Ill Patients: A Retrospective Cohort Study / Bendavid I., Zusman O., Kagan I. [1, c. 755], [2, c. 1245] // Nutrients - 2019. - Vol. 11, №1: 106 doi: 10.3390/ пu11010106

2. Enhanced protein-energy provision via the enteral route feeding protocol in critically ill patients. results of a cluster randomized trial / Heyland D.K., Murch L., Cahill N. [et al.] // Crit Care Med. - 2013. - Vol. 41, N 12. - P. 2743-2753. doi: 10.1097 CCM 0 b013e31829efef5.

УДК 616-089.5-031.81:618.1-089

\section{Халімончик В.В., Клигуненко О.М.}

\section{ВПЛИВ НИЗЬКИХ ДОЗ КЕТАМІНУ НА ЦИТОКІНОВУ ВІДПОВІДЬ ПІСЛЯ ЛАПАРОСКОПІЧНИХ ОПЕРАЦІЙ У ГІНЕКОЛОГІЇ}

\section{ДЗ «Дніпропетровська медична академія МОЗ України»}

Кафедра анестезіології, інтенсивної терапії та медицини невідкладних станів ФПО

Хірургічна травма індукує гостру запальну реакцію, яка включає вроджені та адаптивні імунні фактори. Загальна анестезія може пригнічувати імунну компетентність клітин і впливати на запальну відповідь, в тому числі на концентрацію про- та протизапальних інтерлейкінів $[1,2]$.

\section{META}

Дослідити вплив інтраопераційного застосування кетаміну в субнаркотичних дозах та неопіоїдних анальгетиків на динаміку рівня цитокінів при лапароскопічних операціях у гінекології. 


\section{МАТЕРІАЛИ ТА МЕТОДИ}

45 пацієнток гінекологічного профілю, яким проводилися планові лапароскопічні оперативні втручання, були розподілені на дві групи, порівнювані за віком, антропометричними даними, функціональним станом, характером оперативного втручання. Загальна методика анестезії не відрізнялась в обох групах. Пацієнткам I групи $(\mathrm{n}=25)$ проводилась тотальна внутрішньовенна анестезія (ТВА) 3 штучною вентиляцією легенів (ШВЛ) з використанням пропофолу та фентанілу; II групи $(\mathrm{n}=20)$ - на тлі стандартної ТВА з ШВЛ в якості ад'юванта застосовували кетамін в субнаркотичних дозах та декскетопрофен наприкінці операції. Післяопераційне знеболювання здійснювали плановим введенням декскетопрофену в обох групах.

Концентрацію цитокінів (IL-6, IL-10) у сироватці крові визначали методом імуноферментного аналізу (ELISA) 3 використанням стандартних наборів реагентів до операції, через 2 та 24 години після операції.

\section{РЕЗУЛЬТАТИ}

Через 2 години після операції в обох групах спостерігалось підвищення вмісту IL-6 проти вихідного на $79 \%$ у пацієнток I групи, на 48 \% у пацієнток II групи. На 1 добу після операції рівень IL-6 знижувався проти попереднього етапу, але перевищував вихідний на $10 \%$ у I групі, на $1 \%$ - у II. Зміни рівня IL-10 були подібними. Через 2 години після операції концентрація IL-10 збільшувалась на 16 \% у I групі, на $11 \%$ - у II групі проти вихідної. Через 24 години суттєвої різниці між групами не було.

\section{ВИСНОВКИ}

Інтраопераційне застосування кетаміну в субнаркотичних дозах та декскетопрофену при лапароскопічних операціях у гінекології зменшує запальну відповідь на хірургічну травму, що попереджує вторинне ушкодження органів та тканин.

\section{СПИСОК ЛІТЕРАТУРИ}

1. Schneemilch C. E. Schilling $T$, Bank $U$. Effects of general anaesthesia on inflammation. Best Pract Res Clin Anaesthesiol. 2004. Vol. 18. P. 493-507.

2. Snyder G. L., Greenberg S. Effect of anaesthetic technique and other perioperative factors on cancer recurrence. Br J Anaesth. 2010. Vol. 105. P. 106-115

\title{
ХУхлей В.О., ХИтрий Г.П., Бадюк М.І.
}

\section{АНАЛІЗ СТРУКТУРИ НЕВІДКЛАДНИХ СТАНІВ У ВІЙСЬКОВОСЛУЖБОВЦІВ НА ДОГОСПІТАЛЬНОМУ ЕТАПІ}

\author{
Українська військово-медична академія, м. Київ, Україна
}

\section{ВСТУп}

Різні захворювання, травматичні ушкодження, нещасні випадки, отруєння тощо часто вимагають екстреної медичної допомоги, від своєчасності та якості якої залежать здоров'я й життя пораненого (хворого). Належне надання екстреної медичної допомоги у наданні невідкладних медичних заходів на догоспітальному етапі здатні не лише рятувати життя хворим (постраждалим), а й сприяти подальшому успішному лікуванню, попереджуючи при цьому розвиток тяжких ускладнень.

\section{META}

Обгрунтування потреби у розробці та застосуванні актуальних адаптованих алгоритмів і протоколів надання екстреної медичної допомоги військовослужбовцям у невідкладних станах на основі дослідження структури тяжких станів поранених (хворих).

\section{МАТЕРІАЛИ І МЕТОДИ}

Методи системного підходу та системного аналізу, бібліосемантичний, історичний, медико-статистичний, експертних оцінок.

\section{РЕЗУЛЬТАТИ}

На сьогоднішній день питання розробки нових алгоритмів, протоколів та стандартів надання медичної допомоги військовослужбовцям при тяжкій бойовій травмі чи ускладненнях захворювань в умовах збройного конфлікту, які побудовані на засадах доказової медицини та стандартах НАТО, лишається і досі відкритим. Нами виявлено достовірні відомості щодо основних нозологічних форм бойових травм і захворювань у військовослужбовців, при яких розвиваються невідкладні стани. В структурі тяжких і вкрай тяжких станів поранених за нозологічними формами класу XIX «Травми, отруєння та деякі інші наслідки дії зовнішніх причин» травматичні пошкодження голови та головного мозку складають $27,3 \%$, травми органів черевної порожнини - $18,2 \%$, травми грудної клітки та ребер - 12,9\%, травми кульшових суглобів $7,2 \%$, травми довгих трубчастих кісток $-6,4 \%$ та $25,4 \%$ займають інші тяжкі травми. В структурі тяжких і вкрай тяжких станів хворих за нозологічними формами класу IX «Хвороби системи кровообігу» 40,1\% займають інсульти, 30,1\% - інфаркти міокарда, 12,5\% - гіпертонічна хвороба та 17,3\% належать іншим захворюванням.

\section{висновки}

1. Проведене дослідження невідкладних станів у військовослужбовців свідчить про переважання в структурі тяжких і вкрай тяжких станів поранених (хворих) таких нозологічних форм, як інсульти $(40,1 \%)$, інфаркти міокарда $(30,1 \%)$, травматичні пошкодження голови та головного мозку $(27,3 \%)$, травми органів черевної порожнини $(18,2 \%)$, травми грудної клітки та ребер $(12,9 \%)$, гіпертонічна хвороба (12,5\%).

2. Для покращення якості надання екстреної медичної допомоги пораненим (хворим) з метою збереження життя і швидкого відновлення боєздатності необхідно розробити і запровадити адаптовані алгоритми і протоколи надання медичної допомоги військовослужбовцям, які побудовані на засадах доказової медицини та стандартах НАТО. 
Черній В.І.,євсєєва В.В., Зенкіна Л.М.

\title{
ПОРІВНЯННЯ ЕФЕКТИВНОСТІ ТАР ВLОСК 3 ІНФІЛЬТРАЦІЙНОЮ МІСЦЕВОЮ АНЕСТЕЗІЄЮ ЯК КОМПОНЕНТІВ МУЛЬТИМОДАЛЬНОЇ АНАЛГЕЗІЇ У ХВОРИХ НА МОРБІДНЕ ОЖИРІННЯ ПІД ЧАС ЛАПАРОСКОПІЧНИХ ВТРУЧАНЬ
}

\author{
Державна Наукова Установа «Науково-практичний центр профрілактичної та клінічної медицини» \\ Державного управління справами, м. Київ, Україна \\ Державна Наукова Установа «Центр інноваційних медичних технологій НАН України», м. Київ, Україна, \\ МЦ «Добробут», м. Київ, Україна
}

\section{АКТУАЛЬНІСТЬ}

Лапароскопічні методики в хірургії та принципи прискореного періопераційного (ERAS) анестезіологічного ведення хворих з морбідним ожирінням (МO) вже виправдали себе та повинні розглядатится в якості стандарту хірургічної допомоги для цієї групи пацієнтів. Мультимодальний підхід в періопераційній аналгезії є обов'язковим компонентом програми ERAS. На жаль епідуральна анестезія не завжди технічно можлива, а наркотичне навантаження несе значні ризики для хворих на МО. Тому розробка альтернативних схем періопераційного знеболення у цієї групи пацієнтів залишається актуальним.

\section{META РОБОТИ}

Порівняння ефективності аналгетичної дії ТАР блоку, виконаного за допомогою УЗД - апарату, та інфільтраційної місцевої анестезії троакарних входів в схемі інтраопераційної мультимодальної попереджуючої анестезії у пацієнтів з МО під час лапароскопічних втручань.

\section{МАТЕРІАЛИ І МЕТОДИ}

В дослідження було включено 40 хворих на морбідне ожиріння, 18 чоловіків та 22 жінки віком від 23 до 58 років з IBT 36-45. 12 пацієнтам була виконана лапароскопічна (ЛС) апендектомія, 4 - ТАП, 6 - ТЕП, 6- ЛС консервативна міомектомія, 12- ЛС видалення кісти яєчника. Пацієнти були рандомізовані на 2 групи. Всім пацієнтам була проведена багатокомпонентна низькопотокова інгаляційна анестезія севолфлюраном в поєднанні з попереджуючою мультимодальною аналгезією - в В декскетопрофен 50 мг в поєднанні з парацетамолом 1000 мг в в за 30 хв. до хірургічного розрізу. До першої групи $(\mathrm{n} 1=20)$ увій- шли пацієнти, яким був виконаний білатеральний ТАР блок $2,5 \%$ розчином бупівакаїну під ультразвуковим контролем. В другу групу (n2=20)- пацієнти, яким була виконана інфільтраційна місцева анестезію $2,5 \%$ розчином бупівакаїну в місцях входу троакарів. Оцінювалися наступні показники: параметри інтраопераційної гемодинаміки, інтраопераційна доза опіоїдів, показники післяопераційного болю за ВАШ, необхідність в рятівній аналгезії в перші 6 післяопераційних годин. Статистична обробка результатів дослідження здійснювалась за допомогою пакету аналізу статистичних даних EZR (R-Statistics) та авторського пакету "Medstat".

\section{РЕЗУЛЬТАТИ}

Показники гемодинаміки в обох групах суттєво не відрізнялися між собою в продовж операції та знаходилися в межах інтраопераційної стрес-норми. В групі ТАР блоку $(\mathrm{n} 1=20)$ була суттєво знижена інтраопераційна доза фентанілу: 1,34 $\pm 0,15$ мкг/кг/год проти 2,2 $\pm 0,18$ мкг/кг/ год в другій групі, $(\mathrm{p}=0,032)$. Рівень болю за ВАШ у пацієнтів в обох групах був в середньому 2-4 бали, відповідно, необхідності в рятівній аналгезії не було. Але у пацієнтів другої групи показники рівню болю за ВАШ мали статистично незначущу тенденцію до зростання до 4 післяопераційної години.

\section{ВИСНОВКИ}

ТАР блок має аналгетичні та опіоїдозберігаючі переваги перед інфільтраційною місцевою анестезією у хворих на МО під час лапороскопічних втручань.

УДК 616.3-089.5-006.058+615.211:658.14

Черній В.І., Науменко О.В., Штомпель І.В. ПІД ЧАС ІНГАЛЯЦІЙНОÏ АНЕСТЕЗІЇ ЗА МЕТОДОМ MINIMAL FLOW ANESTHESIA, ЯК ОСНОВА IНTРАОПЕРАЦІЙНОГО «МЕТАБОЛІЧНОГО» МОНІТОРИНГУ ТА БЕЗПЕКИ ПАЦІЄНТА

Державна наукова установа «Науково-практичний центр профрілактичної та клінічної медицини» Державного управління справами, м. Київ, Україна.

\section{АКТУАЛЬНІСТЬ ПРОБЛЕМИ}

Метод Minimal Flow Anesthesia в інгаляційній анестезіі виявився одним з найбільш перспективних, оскільки зниження потоку газу дозволяє створити оптимальний мікроклімат в дихальному контурі, значно знизити витрати коштовних інгаляційних анестетиків та вартість анестезіологічного забезпечення оперативного втручання.
META РОБОТИ

Покращення якості та безпеки загальної анестезії при лапароскопічних антирефлюксних операціях в абдомінальній хірургії, шляхом постійного інтраопераційного моніторингу споживання кисню пацієнтом при анестезії севофлураном за методом Minimal Flow Anesthesia. 


\section{МАТЕРІАЛИ ТА МЕТОДИ}

Досліджено 40 хворих із грижею стравохідного відділу діафрагми, яким було виконано оперативне втручання лапароскопічну крурорафію та фундоплікацію. Хворих було розподілено на такі групи: 1-ша група (20 хворих) інгаляційна анестезія севофлураном із киснем, потік свіжої суміші 1 л/хв; 2-га група (20 хворих) - інгаляційна анестезія севофлураном із киснем, потік свіжої суміші d" 0.5 л/хв. Усім хворим було проведено загальну комбіновану анестезію з інтубацією трахеї та штучною вентиляцією легень. Анестезія проводилась на анестезіологічній станції Drager Fabios Tiro (Німеччина). Як газ-носій використовували $100 \%$ кисень. Інтраопераційний моніторинг проводили монітором пацієнта Drager Infinity Delta (США). Показники глибини анестезії - за даними БІС. Проводився постійний моніторинг показників газообміну - капнографії, концентрації кисню, севофлурану у суміші на вдиху й видиху, параметрів вентиляції. Окрім того, постійно проводився контроль споживання кисню організмом пацієнта, за допомогою парамагнітних датчиків точного вимірювання концентрацій газу в режимі реального часу та розрахунок запропонованою нами формулою:

$\mathrm{VO2}=($ FIO2 - FexpO2 (\%)) x AV (L) x 10 де,

FIO2 - концентрація кисню на вдосі (\%)

$\mathrm{FexpO2}$ - концентрація кисню на видосі (\%)

$\mathrm{AV}$ - хвилинний альвеолярний об‘ $є$ м вентиляції (л), $\mathrm{AV}=(\mathrm{VT}-\mathrm{VD}) \times \mathrm{f}$ де,
VT - дихальний об“єм

VD - фізіологічний мертвий простір (мл) прийнявши, що $\mathrm{VD}=2 \mathrm{KG}[$ кг $]=$ маса тіла в кг

$\mathrm{F}$ - частота дихання.

\section{РЕЗУЛЬТАТИ}

Методика дозволяє індивідуалізувати розрахунок споживання кисню пацієнтом в до- та інтраопераційному періоді та зробити його більш точним за рахунок врахування конкретної маси кожного пацієнта.

\section{висновки}

На даний час, вже більшість сучасних інгаляційних станцій обладнано парамагнітними датчиками точного вимірювання концентрацій газу в режимі реального часу. Це робить, розроблену методику зручною, неінвазивною та доступною для використання в умовах операційної.

\section{ЛITEPATУРA}

1. Brody J.S New York: Reinhold; 1945. Bioenergetics and Growth with Special Reference to the Efficiency Complex in Domestic Animals

2. Metha Brattwall, MD PhD • Margareta Warre.n-Stomberg, PhD Fredrik Hesselvik, MD, PhD • Jan Jakobsson, MD, PhD Brief review: Theory and practice of minimal fresh gas flow, PhD Brief review. Theory and practice of minimal fresh

3. Sykes O. Oxygen monitoring during low flow anaesthesia. Journal of Clinical Monitoring and Computing 2010; 24:141.

4. Shibutani K, Komatsu T, Keshav K, Sanchala V Kumar V, Bizzarri D. Critical level of oxygen delivery in anesthetized man.Critical Care Critical level of oxygen delin

S. RitchieMcLean and R. Shankar, Calculating oxygen consumption during lowflow anaesthesia.

УДК 616.12-005.4-089+ 616.12-077-008.46

Черній В.І., Куриленко Я.В., Собанська Л.О., Тополов П.О.

\section{ДИФЕРЕНЦІЙОВАНИЙ ПІДХІД ДО ЛІКУВАННЯ ГОСТРОЇ СЕРЦЕВОЇ НЕДОСТАТНОСТІ, ЩО ВИНИКАЄ ПІСЛЯ АОРТОКОРОНАРНОГО ШУНТУВАННЯ У ХВОРИХ НА ІШЕМІЧНУ ХВОРОБУ СЕРЦЯ}

Державна наукова установа «Науково-практичний центр профрілактичної та клінічної медицини» Державного управління справами, м.Київ, Україна

\section{АКТУАЛЬНІСТЬ}

Частота гострої серцевої недостатності після операції на відкритому серці становить 3,6-15,4\%. Аортокоронарне шунтування пов'язано з ризиком розвитку пошкодження міокарду та серцевої недостатності під час операції, що погіршує, таким чином, перебіг післяопераційного періоду та довгостроковий клінічний прогноз.

\section{МЕТА ДОСЛІДЖЕННЯ}

Розробити диференційований підхід до корекції гемодинамічних розладів в післяопераційному періоді кардіохірургічних хворих з серцевою недостатністю, що перенесли шунтування коронарних артерій з застосуванням екстракорпорального кровообігу шляхом удосконалення протоколу періопераційного ведення пацієнтів.

\section{МАТЕРІАЛ І МЕТОДИ ДОСЛІДЖЕНЬ}

На базі ДНУ «НПЦ ПКМ» ДУС було прооперовано 80 кардіохірургічних хворих з використанням штучного кровообігу. Пацієнти були поділені на дві групи. Пацієнтам групи 1 (40 хворих) в післяопераційному періоді корекцію гемодинамічних розладів виконували за стандартним чинним протоколом $[1,2]$. В групі 2 (40 хворих) - був застосований диференційований підхід до корекції гемодинамічних розладів: підгрупа 1 (20 хворих) в післяопераційному періоді корекціїю гемодинамічних розладів виконували за допомогою добутаміну та досягли стабілізації; підгрупа 2 (11 хворих, у яких була діагностована в передопераційному періоді гіпофосфатемія) - для корекції гемодинамічних розладів, крім добутаміну, використовували препарат Фруктозо-1,6-дифосфат за схемою: 5гр. препарату вводили безпосередньо перед початком перфузії і 5гр на 30 хвилині штучного кровообігу. Препарат, ендогенний високоенергетичний проміжний метаболіт гліколітичного шляху, безпосередньо підвищує утворення високоенергетичного фосфату (АТФ); в підгрупі 3 (6 хворих) в післяопераційному періоді, крім добутаміну, для корекції гемодинамічних розладів застосували препарат Тиворель (1 мл розчину містить 42 мг аргініну гідрохлориду та 20 мг левокарнітину). Аргінін чинить антигіпоксичну, мембраностабілізуючу, цитопротекторну, антиоксидантну, антирадикальну, дезінтоксикаційну дію, проявляє себе як активний регулятор процесів енергозабезпечення. Левокарнітин необхідний для транспортування довголанцюгових жирних кислоту мітохондрії для їх подальшого бета-окислення й утворення енергії в міокарді. Підгрупа 4 (3 хворих) в післяопераційному періоді не мали гемодинамічних розладів, корекцію не виконували.

Для моноторінга функції серцево-судинної системи використовували фазаграфію - дослідження симетрії асимметрії зубця Т електрокардіограми, як маркера ішемічних змін міокарду [3], ЕКГ, ЕхоКГ, ВСР, центральну 


\section{Шкурупій Д.А. \\ TРАВМА ВІЙСЬКОВИМ ВИБУХОВИМ ПРИСТРОЄМ У ДІТЕЙ НА МИРНІЙ ТЕРИТОРІЇ: КЛІНІЧНИЙ ВИПАДОК}

Українська медична стоматологічна академія м. Полтава, Україна

\section{АКТУАЛЬНІСТЬ ПРОБЛЕМИ}

За даними Всесвітньої організації охорони здоров'я щороку в світі близько 5,8 млн осіб помирають від травм. Найбільш гостро ця проблема стоїть в країнах з низьким та середнім рівнями доходів [1].

\section{META РОБОТИ}

Оприлюднення випадку травми військовим вибуховим пристроєм в дитячому віці на мирній території.

\section{МАТЕРІАЛИ ТА МЕТОДИ}

Сім неповнолітніх осіб віком від 12 до 14 років, отримали множинні травми внаслідок вибуху військового пристрою у житловому приміщенні. Один постраждалий загинув на місці події. Шістьох постраждалих евакуювали до територіальної лікарні.

\section{РЕЗУЛЬТАТИ}

Вибухові травми мають множинний характер за рахунок уламків вибухового пристрою. При розчавлені м'яких тканин правильно накладений джгут не призвів до повної зупинки кровотечі. Більший вклад у відновлення гемодинаміки у дітей із тяжким травматичним шоком вносить використання швидкого і великого обсягу інфузії, аніж інфузії симпатоміметиків і вазоперсорів. Цей ефект відображується навіть при рутинному контролі показ- ників гемодинаміки в умовах обмежених діагностичних ресурсів, що збігається 3 даними інших авторів $[2,3]$.

\section{висновок}

Вибухова травма в закритому приміщені продемонструвала високий обсяг ураження і травматичність ураження. Ефективність лікування масової вибухової травми залежить від характеру організаційних заходів з транспортування, сортування і лікування постраждалих. В умовах високої травми кінцівок і розчавлення м'яких тканин стандартний правильно накладений кровоспинний джгут може бути недостатньо ефективним, що потребуватиме застосування додаткових методів тимчасової зупинки кровотечі. $\mathrm{У}$ дітей із тяжким травматичним шоком слід очікувати більший позитивний гемодинамічний ефект від високошвидкісної великооб'ємної інфузійно-трансфузійної терапії, аніж від інфузії симпатоміметиків.

\section{СПИСОК ЛІТЕРАТУРИ}

1. WHO Library Cataloguing-in-Publication Data Guidelines for trauma quality improvement programmes. Geneva: World Health Organization; 2010,104

2. Guizhou Zhu, Yuhong Li, Guomei Ru, Qiannan Ding. Comparison of the hemodynamics and dynamics of fluid shift of Ringer's solution before surgery in children and adults. Exp Ther Med. 2017; 13(6): 3146-3152.

3. Anke PC, Tasker RC, Can I. The microcirculation of the critically ill pediatric patient. Critical Care 2011; 15: 213.

\section{МЕТАБОЛІЧНІ ЛАНКИ ІНТЕРКУРЕНТНОСТІ ПРИ ГОСТРІЙ ЦЕРЕБРАЛЬНІЙ НЕДОСТАТНОСТІ}

Українська медична стоматологічна академія м. Полтава, Україна

\section{АКТУАЛЬНІСТЬ ПРОБЛЕМИ}

Функція нервової системи як провідного регулятора i адаптера організму як відкритої біологічної системи є загальновідомою і беззаперечною. Останнім часом підвищився інтерес до позанейрональних зв'язків нервової системи з іншими органами і системами як в фізіологічних умовах, так і при патології $[1,2]$.

\section{META РОБОТИ}

Встановити зв'язки гострої церебральної недостатності (ГЦН) із маркерами метаболічних змін екстрацеребральНого гомеостазу.

\section{МАТЕРІАЛИ ТА МЕТОДИ}

Проведено обстеження 94 пацієнтів із ознаками ГЦН, які потребували IT. Досліджували кореляційні зв'язки у пацієнтів із СГІН між вмістом цинку, нейрон-специфічної енолази (НСЕ), тіолових сполук (ТС), інтестинального білку, що зв'язує жирні кислоти (ІБЗЖК), активністю супероксиддисмутази (СОД).

\section{РЕЗУЛЬТАТИ}

В процесі дослідження отримані значимі кореляційні зв'язки:
- $\mathrm{HCE}-\mathrm{TC}: \mathrm{R}=-0,37 ; \mathrm{p}=0,036$;

- HCE - ІБЗЖК: $\mathrm{R}=0,56 ; \mathrm{p}=0,031$;

- СОД (1-а доба) - цинк: $\mathrm{R}=0,67 ; \mathrm{p}<0,001$;

- ІІБЗЖК (7-а доба) - цинк: $\mathrm{R}=0,73 ; \mathrm{p}=0,002$;

- ІБЗЗЖК (7-а доба) - ТC: $\mathrm{R}=-0,57 ; \mathrm{p}=0,007$;

- $\mathrm{TC}(7-\mathrm{a}$ доба) - цинк: $\mathrm{R}=0,5 ; \mathrm{p}=0,007$;

- $\mathrm{TC}(7-\mathrm{a}$ доба) - СОД: $\mathrm{R}=0,4 ; \mathrm{p}=0,037$;

-

- ІЛ-1 (1-а доба) - ТC: R=-0,45; $\mathrm{p}=0,01$.

\section{ВИСНОВОК}

У пацієнтів відділень IT кореляційні зв'язки доводять наявність інтеркурентності між ГЦН, гастроінтестинальною недостатністю, змінами антиоксидантної системи. Ці зміни реалізуються через порушення вмісту цинку і тіолових сполук.

\section{СПИСОК ЛІТЕРАТУРИ}

1. Маслов Л.Н., Цибульников С.Ю., Цепокина А.В. (и др.). Нейропротекторный и нефропротекторный эффекты дистантного прекондиционирования. Перспективы клинического применения Tерапевтический архив.. - 2016. - 88(8). - 121-126.

2. Martin C.R., Osadchiy V., Kalani A., Mayer E.A. The Brain-GutMicrobiome Axis. Cell Mol Gastroenterol Hepatol. - 2018. - 6(2). $133-148$. 
Юрченко О. М., Георгіяни М. А.

\section{ХАРАКТЕРИСТИКА РОЗВИТКУ БОЛЬОВОГО СИНДРОМУ ПІСЛЯ ПРОВЕДЕННЯ ВИШКРІБАННЯ ПОРОЖНИНИ МАТКИ В УМОВАХ РІЗНИХ ВИДІВ АНЕСТЕЗІЇ}

\section{АКТУАЛЬНІСТЬ}

Вишкрібання порожнини матки (ВПМ), як і будь-яке оперативне втручання, призводить до розвитку післяопераційного больового синдрому (ПБС). Його інтенсивність та час розвитку може залежати від виду знеболення, в умовах якого проводилося втручання.

\section{META}

Визначити вплив виду анестезії при ВПМ на динаміку інтенсивності ПБС.

\section{МАТЕРІАЛИ ТА МЕТОДИ}

ВПМ виконано 128 жінкам, середній вік яких склав $42,5 \pm 0,7$ роки. В залежності від виду анестезії пацієнтки розподілені на 4 групи: I ( $\mathrm{n}=32), \mathrm{II}(\mathrm{n}=32), \mathrm{IV}(\mathrm{n}=32)$ В I групі проводилась в/в анестезія - кетамін 2 мг/кг, фентаніл 2 мкг/кг, пропофол 2 мг/кг. Пацієнткам групи II додавався декскетопрофен 50 мг/кг; групи IV - аплікаційна обробка ранової поверхні бупівакаїном $0,25 \% 5,0$ мл. Група III (n=32) - кетамін 1 мг/кг, фентаніл 1 мкг/кг, пропофол 2 мг/кг, декскетопрофен 50 мг/кг.

Маркером, який характеризує зміну інтенсивності ПБС, обрано сироватковий рівень кортизолу, - один 3 основних біохімічних маркерів стресу. Його рівень досліджувався у 5 часових контрольних точках (КТ): 1 - до початку ВПМ, 2 - одразу після його закінчення та відновлення свідомості пацієнтки, 3 - через 1 год, 4 - через 3 год, та 5 - через 6 год після відновлення свідомості.

\section{РЕЗУЛЬТАТИ}

В усіх групах, крім IV, спостерігалось збільшення показників з 1-ї до 3-ї КT. Лише у IV групі між 2-ю та 3-ю КТ відбувалось зменшення рівня сироваткового кортизолу. Цей показник мав найнижчі рівні в усіх КТ у пацієнток IV групи порівняно 3 іншими групами $(\mathrm{p}<0,001)$. Починаючи з 4-ї КТ (3 год після відновлення свідомості), рівень сироваткового кортизолу істотно зменшувався в усіх групах і ставав меншим за рівні у 1-й КТ, яка показувала рівень стресу до оперативного втручання, а у 5-й КТ його рівень був найнижчим серед усіх КТ у всіх досліджуваних групах. Усе це свідчить про безумовну ефективність превентивної інтраопераційної аплікаційної анестезії ВПМ бупівакаїном у перші 3 год післяопераційного періоду проти інших досліджуваних методів анестезії ВПМ.

\section{висновки}

Метод превентивної інтраопераційної аплікаційної анестезії ВПМ ефективно запобігає розвиткові ПБС, навіть у перші 3 год післяопераційного періоду.

\section{СПИСОК ЛІТЕРАТУРИ}

1. Buvanendran A, Fiala J, Patel KA, Golden AD, Moric M, Kroin JS. The Incidence and Severity of Postoperative Pain following Inpatient The Incidence and Severity of Postoperative
Surgery. Pain Med. 2015;16(12): 2277-83.

2. Luangtangvarodom W, Pongrojpaw D, Chanthasenanont A, Pattaraarchachai $J$, Bhamarapravatana K, Suwannarurk K. The Efficacy of Lidocaine Spray in Pain Relief during Outpatient-Based Endometrial Sampling: A Randomized Placebo-Controlled Trial. Pain Res Treat. 2018: 2018: 1238627 .

3. Vadivelu $N$, Mitra S Schermer E, Kodumudi V, Kaye AD, Urman RD. Preventive analgesia for postoperative pain control: $A$ broader concept. Local Reg Anesth. 2014; 7: 17-22. 